University of Rhode Island

DigitalCommons@URI

Open Access Master's Theses

1999

\title{
BETWEEN TWO FAITHS: THE ARABIZATION OF THE KNIGHTS TEMPLAR DURING THE CRUSADES
}

Paula Regina Stiles

University of Rhode Island

Follow this and additional works at: https://digitalcommons.uri.edu/theses

\section{Recommended Citation}

Stiles, Paula Regina, "BETWEEN TWO FAITHS: THE ARABIZATION OF THE KNIGHTS TEMPLAR DURING THE CRUSADES" (1999). Open Access Master's Theses. Paper 1805.

https://digitalcommons.uri.edu/theses/1805

This Thesis is brought to you for free and open access by DigitalCommons@URI. It has been accepted for inclusion in Open Access Master's Theses by an authorized administrator of DigitalCommons@URI. For more information, please contact digitalcommons-group@uri.edu. 


\section{BETWEEN TWO FAITHS:}

THE ARABIZATION OF THE KNIGHTS TEMPLAR

DURING THE CRUSADES

BY

PAULA REGINA STILES

A THESIS SUBMITTED IN PARTIAL FULFILLMENT OF THE REQUIREMENTS FOR THE DEGREE OF

MASTER OF ARTS

IN

HISTORY

\#43367839

UNIVERSITY OF RHODE ISLAND

1999 


\begin{abstract}
\end{abstract}
"Between Two Worlds: The Arabization of the Knights Templar during the Crusades, 1119-1314."

Paula Stiles

The military orders, especially the first, the Order of the Poor Knights of the Temple of Solomon (Knights Templar) played a critical role in the preservation of the Crusader kingdoms in Palestine between 1119 and their fall in 1291. It is generally acknowledged that part of the Templars' success, in both Palestine and Spain, stemmed from their ability to deal with the Muslim enemy in a variety of situations. This naturally involved some assimilation of the Templars into the local culture during the 12th and 13th centuries.

This thesis explores the nature of that assimilation (either arabization or islamization), and how it changed over time and geography. The Templars' arabization appears to have been an adaptive mechanism. There is apparently no more tolerance toward Islam inherent in the Order's structure than in other medieval Christian institutions. Under the right conditions, Templars could be as intolerant as any other Christian group of the era.

The Templars came under severe criticism during this period for their real, and perceived arabization. Their perceived arabization was, in fact, much greater than their real assimilation. It was this perception which brought about their eventual downfall.

Chapters One and Two discuss the overall career of the Templars: their origins, their rise, their success in Palestine and Spain, and their sudden 
suppression, which ended with the burning of their last Master in 1314.

Chapter Three gives an overview of the Crusades, both in Palestine and in Spain (the Reconquista). Chapter Four explores the nature of the arabization of the Templars, both real and perceived, its limits, how it affected their place in medieval society, and how it led to their suppression. Chapter Five discusses how, and why, the perceived arabization of the Templars has affected their place in history, even leading some modern groups to imitate the fantasies created to destroy the Order. 


\section{Acknowledgement}

Research for this scholarship was funded by a Tuition Scholarship and Teaching Assistantship through the History Department at the University of Rhode Island, the H.W. Wilson Scholarship for Library Science students with an interest in History, and the Catherine \& Walter Eckman Scholarship in History. I would also like to thank the Cape Cod National Seashore and Gordon Hollister, my supervisor there, for providing me with summer employment that helped fund the writing of this thesis for the past two years.

I would like to thank my thesis committee, Dr. Joelle Rollo-Koster, Dr. Gary Thurston, Dr. Kenneth Rogers, and Dr. Jonathan Tryon for taking the time to go through this thesis and ensure that it was of high quality. I would especially like to thank Dr. Rollo-Koster for answering my questions and providing encouragement, even outside of class time, and for helping me avoid the Von Daniken school of writing which prevails in too many works on this subject.

I would like to thank the senior clerk in the History department, Louise Hilliard, and the administrative secretary in the Library Science department, Rosemary Northup, for helping me juggle the requirements of two degrees while writing my thesis. I would also like to thank the Graduate School office personnel, who walked me through the paperwork for my defense.

Finally, I would like to thank my family and friends for listening patiently to long declamations about medieval heresy, the military orders, and the Crusades. I would especially like to thank my mother, Bonnie Dee Stiles, my brother, Mikhail Stiles, my grandparents, John and Ruth Stiles, and my friends, Carol Pinney, Cheryl Madden, and Ameni Darwish for giving me their love and support throughout this process. 


\section{Preface}

This thesis is an essay in the history of mentalities--a discipline which explores how people's ideas evolve over time. It examines the Knights Templar and their legacy in medieval, and modern, popular culture. The Templars were an order of fighting monks founded in 1119, during the Crusades. As the creators of the first military religious order, they garnered more praise--and more criticism--than subsequent religious knights. Their assimilation into local Arab culture is generally assumed. Since historians do not contest this cultural interchange, this essay concentrates on the nature, extent, and chronological progression of the Templars' arabization. Then, it examines how real, and perceived, cultural assimilation fueled criticism during their heyday, and their posthumous reputation as exotic, mysterious sorcerers.

This essay examines both primary sources (chronicles, cartularies, court documents, and contemporary fiction) and secondary literature. The latter will focus on the Templars, as well as the Palestinian and Spanish Crusades--to show how members of the Order became assimilated into local Arab culture.

The paper consists of five chapters. The first three discuss the Templars' organization, as well as the Palestinian and Spanish crusades. Chapters One and Two look at the history of the Templars, and how this subject has been treated in secondary literature. The Order's historiography is separate from that of the Spanish and Palestinian Crusades, with different historians 
dominating in each of the three areas.

Studies of the Crusades in Palestine, of the wars against Germanic and Slavic pagans in northern Europe, and of the Spanish Reconquista, overlap frequently throughout the histories of the military orders because these groups operated on all three frontiers. This essay explores the similarities--and differences--in Templar arabization during the Palestinian and Spanish Crusades, and how local conditions affected cultural assimilation. The paper does not explore the Northern Crusades in detail for two reasons: one, the Templars had only a small role in the North and, two, there were no Arabs or Muslims in these regions.

Chapter Three discusses the Crusades in Palestine and Spain and the cross-cultural issues between Crusaders and Arabs--both Christian and Muslim. The chapter also explores how the Crusades in Spain were affected by the fact that they occurred on a European frontier and how relations between Christians and Muslims changed as the former began to outnumber the latter in the Iberian peninsula.

The fourth chapter discusses how the Templars became partially assimilated into Arab culture. It outlines the extent, nature, and pattern, as well as the chronological and local fluctuations, of Templar arabization.

Chapter Five investigates why the Templars continue to be popular today, and why so many organizations claim descent from them. This chapter suggests that the Templars' posthumous reputation and "afterlife" have been enhanced by their perceived islamization before 1314 , as outlined in the charges at their trial. What is unique in their nature stems from their perceived role as a cultural bridge.

The Order of the Temple was put on trial for heresy by the French king, 
Philip IV (the Fair) in 1307 and was dissolved by Pope Clement V in 1311. Some early 14th century writers, such as Pierre Dubois and Ramon Lull, had accused the Templars of selling out the Crusader kingdom (which fell in 1291) to the Muslims, but these rumours of arabization did not directly appear in the charges. Instead, Philip's lawyers tried the Templars for heresy and witchcraft.

Because of their chronic insolvency and lack of manpower in Palestine, the Templars were forced into much closer relations with the Muslims there than most Europeans found comfortable. This closeness led to the charges that destroyed them. There were five principal accusations: the denial of Christ, desecration of the crucifix through trampling or spitting, obscene ritual kisses, sodomy, and "Islamic" idolatry. The first three were said to have been conducted at the initiation of a new Templar, thus tainting his entire career. This paper shows that these charges were based on contemporary views of Islam, and reflected Latin Christians' terror of infection by heresies from the East, like Islam and Catharism. Guillaume de Nogaret, the author of the charges, came from Toulouse, in southern France. This area was the center of the Albigensian Crusade in the early thirteenth century and had been subject to Muslim influence in previous centuries.

Finally, this paper discusses how European views of Islam since the Templar suppression in 1314 have affected Templar posterity. Despite their official dissolution 688 years ago, they are more popular now than ever before. Several groups claim to be directly descended from the order, even taking the order's name. Many of these groups claim a connection--through the Templars--with Eastern mysticism. Others believe that the Order still exists as a sinister secret society accused variously of black magic, kidnapping, ritualistic murder, and plotting world domination with a secret Jewish cabal 
(Ironically, the Ku Klux Klan was also founded by a neo-Templar group--the Freemasons. The Masonic Temple eventually disavowed the Klan.).

Still others see the Templars as New Age warriors for the forces of Light-connecting them variously with the Grail, the Holy Lance, the True Cross, and the Shroud of Turin. All of these relics of Christ's Passion are reputed to come from the East. The Grail connection is the oldest, extending back to Wolfram von Eschenbach's 12th century poem, Parzival.

The greatest difficulty in research on the Templars lies not in finding information, but in separating the reliable from the spurious. The best lies are never woven from whole cloth, and this is especially true in the case of the Templars. This thesis tries to illuminate some previously unexplored corners of this subject. Beauseant. 


\section{TABLE OF CONTENTS}

ABSTRACT .................... ii

ACKNOWLEDGEMENT ......................... iv

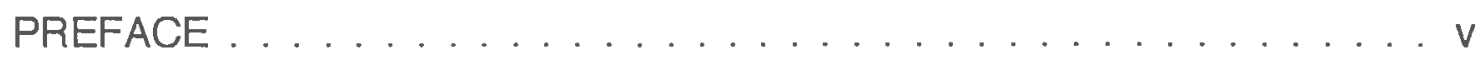

TABLE OF CONTENTS ....................... . . . . . .

LIST OF FIGURES . . . . . . . . . . . . . . . . . . . . . . X

CHAPTER I. The Templars: Their Rise . . . . . . . . . . . . 1

CHAPTER II. The Templars: Their Fall . . . . . . . . . . . 37

CHAPTER III. The Crusades: An Overview . . . . . . . . . . . . . . . 80

CHAPTER IV. Arabization . . . . . . . . . . . . 103

CHAPTER V. Survivals . . . . . . . . . . . . . . 141

CONCLUSION . . . . . . . . . . . . . . . . . . . . . . . . . . . .

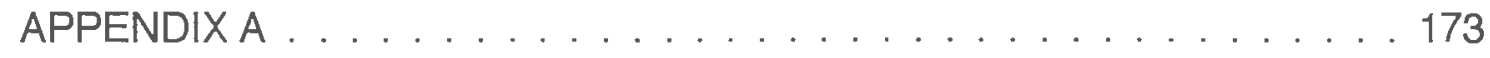

APPENDIX B . . . . . . . . . . . . . . . . . . . 177

APPENDIXC . . . . . . . . . . . . . . . . . . 187

BIBLIOGRAPHY . . . . . . . . . . . . . . . . . . . . . 189 


\section{List of Figures}

Map: Outremer: The Crusader Kingdoms, 1099-1291 


\section{CHAPTER ONE: THE TEMPLARS--THEIR RISE}

\section{Origins}

In 1119, twenty years after the successful conclusion of the First Crusade, a small group of Frankish knights (the traditional number is nine) formed a lay religious organization in Jerusalem based on the newly discovered Augustinian Rule. 1 They took the triple monastic vow of chastity, poverty, and obedience traditionally required for those who chose to follow a monastic life. Monks were called "regular" clergy because they lived apart from society, according to a Rule (Regula). A Rule was a set of regulations for daily convent living which demonstrated, through word and action, a monastic group's purpose in Christian society. The Templars were not originally monks, however, but regular canons (pious laymen who lived outside of the monastery). 2

Rather than flee the world and reject their fighting skills, as regular monks would, these men used them to solve one of the major problems in the new kingdom of Jerusalem; they created a bodyguard to protect pilgrims from marauders on Palestine's roads. Ironically, this was a group from which 1 St. Augustine originally drew up his Rule in a letter (\#211) at the request for guidance by his sister, who was an abbess. It predated Benedict's Rule (which became the medieval standard) by over a century. This Rule was neglected until the 11th century, when it was rediscovered and updated. It became the basis for the Dominican Rule and regulations for later medieval mixed orders. It was not notably different, in principle, from the Benedictine Rule, which would explain why the Templars did not hesitate to switch over to the latter rule 10 years later; C.H. Lawrence, Medieval Monasticism (New York: Longman Group Ltd., 1984), 138-40.

2 William, Archbishop of Tyre, A History of Deeds Done Beyond the Sea, vol 1, trans. Emily Atwater Babcock (New York: Columbia University Press, 1943), 524-5. 
pilgrims of all faiths (not just Christians) could benefit.

Between 1119 and 1314, this group became one of the most powerful organizations in medieval society before it was crushed by the avaricious King Philip IV (the Fair) and his unscrupulous ministers. Philip's lawyers capitalized on European prejudices against Muslims, and a critical atmosphere toward the military orders, to destroy the Templars.

This organization--called variously: (al-dauiyeh), 3 Milites Templi, 4 Fratres, Freres, Templiers, the Temple, the Order of the Temple, the Poor Brothers in Christ, the Poor Knights of the Temple of Solomon, and the Templars--grew into a powerful international military religious order that was both admired and reviled during its lifetime--and afterward. Although the King of Jerusalem offered them quarters on the Temple Mount in the Holy City around 1120 (hence their name), the Templars were independent, even of him, from the beginning. Of the original group of nine Templars, several had been vassals of Hugh, the Count of Champagne. Hugh would negate this fealty within ten years by joining the Templars as an ordinary knight. 5

The first ten years of the Temple were difficult. According to a later chronicler (they were ignored by contemporary chroniclers in Palestine), the original Templars were so poor that they had to rely on local charity for food,

3 Munir Baálbaki, Al-Mawrid [A Modern English-Arabic Dictionary], 13th ed., (Beirut: Dar-El-Ilm Lit-Malayen, 1967), 956; L'Académie des Inscriptions et Belles-Lettres, Recueil des Historiens des Croisades: Historiens Orientaux (RHCr. Or.) [Anthology of Historians of the Crusades: Eastern Historians], vol. 1. (Paris: Imprimerie Nationale, [1872]), 860. The Recueil is more scholarly than Al-Mawrid (which is a popular, illustrated Arabic dictionary of the same type as the American Heritage Dictionary) but transliterates the term as ad-daouia (the-Templars) which leaves out the lem $(L)$ after the aleph $(A)$ in al (the). Neither source explains the origin of the term, which is obscure. In contrast, the term for the Hospitallers, (al-Isbitaria) is simply the transliteration of their French name into Arabic.

4 Malcoim Barber, The New Knighthood: A History of the Order of the Temple (Cambridge: Cambridge University Press, 1994), 56. This term derives from a papal bull of 1144.

5 Ibid., 11. 
clothing, and supplies. 6 They had no specific uniform. Everything from their clothes to their quarters on the Temple Mount consisted of dilapidated handme-downs.

This early penury probably resulted in their later obsession with money, which invited clerical accusations of corporate avarice. When money and possessions began to flow in during the 1130's and 1140's, the Templars immediately set up a system to catalog and maintain them. They were already solvent enough by the Second Crusade (1149-50) to lend money to the King of France. 7

There is no direct evidence of the Templars' military activities in their first ten years of existence. At this time, the Palestinian nobles (and the King of Jerusalem) were at the height of their power. Before the Second Crusade, the Templars were so minor a group that no early 12th century European chronicler mentioned them.

Their first recorded military action (helping the Franks attack Damascus in 1129) did not occur until the year after their confirmation as a monastic order. Their next recorded conflict, the Frankish defense of Montferrand in Tripoli against Zengi, Atabeg of Mosul, came nearly a decade later, in 1137. They lost both. $8 \mathrm{~A}$ third conflict (a minor battle) ended in disaster in 1139.

Initially, Templar strength was concentrated in the Amanus Mountains between Antioch and Armenian Cilicia. Five out of six of the major fortresses

6 William of Tyre, A History of Deeds Done Beyond the Sea, vol 1, 525 .

7 lbid., 67.

8 These two conflicts were recorded by William of Tyre, who wrote during the latter half of the 12th century. William is a careful historian--save for his virulent hostility toward the military orders. He downplays the Temple's influence in its early years (citing the symbolic--and unlikely-number of nine for the Order's membership between 1119 and 1129, for example) in order to present a historical arc in the Order's evolution of rising from humble origins to corrupt heights during his lifetime. Lacking any surviving 12th century Templar historians comparable to the Order's 13th century defender, the Templar of Tyre, the historian must make do with William, and other biased chroniclers; Malcolm Barber, The New Knighthood, 35, 78. 
that the Templars acquired in the 1130's guarded these far northern passes. Later, in the 1150's, their influence extended farther down the coast to Gaza. The defense of these passes may have taught the Templars the experience with Turkish military tactics that they later demonstrated in protecting King Louis VII of France's baggage train during his army's journey through Asia Minor to Palestine.

Though the nature of their activities during the 1120's and 1130's remains obscure, they were clearly successful, despite their poverty. Most contemporary evidence of the early Templars stems from charters, bequests, and clerical correspondence. ${ }^{9}$ Their most notable activity at this time was property acquisition. By 1130, the Templars were receiving grants of land and money from southern France and Spain. Most Spanish gifts of land specifically mentioned the Templar's military function as a frontier guard for the Spanish crusade. This indicates that they had already scored some military successes on the peninsula that the chroniclers did not report; the Spanish had neither the funds nor the patience to support a group that could not substantially help in the Reconquista of the Iberian peninsula. 10

Though the Templars were not yet a military power of note in Palestine, they were already one in Spain. So established were they in local politics by 1134 that when Alfonso I (the Battler) of Aragon died childless that year, he left a third of his kingdom to the Templars. He left another third each to the Hospitallers and to the obscure Canons of the Holy Sepulchre. The will shocked Alfonso's vassals and neighbors. ${ }^{11}$

Eventually, a compromise, in which all three of the original beneficiaries

9 Malcolm Barber, The New Knighthood, 394-5.

10 A.J. Forey, The Templars in the Corona de Aragón (London: Oxford University Press, 1973), 40-51.

11 Malcolm Barber, The New Knighthood, 27-31. 
profited handsomely, was worked out. Alfonso's brother had become a monk. He was given leave to depart the monastery he had entered, to become the new King of Aragon. Some historians who have investigated the will now. believe that Alfonso had no intention of leaving his kingdom to these three orders. Instead, they believe that he had written his will (with the knowledge of his beneficiaries) to continue his line by giving his brother time to escape his vows and establish his own power base. 12

The scandal of Alfonso's will created temporary resentment against these orders amongst the other clerics, but also raised their profile in the peninsula. For an Order like the Temple, which had been founded only fifteen years before, and officially recognized only five years previously, it was a propaganda coup. Perhaps Alfonso chose the Templars and the other two orders because he wanted new blood, or perhaps he did it only to distract his nobles through outrage while his brother entrenched himself. We only know the results. 13

The Templars were less integrated into the Frankish military structure in Palestine than they were in Spain. They were obviously important enough to acquire their own rule in 1129 , to influence the Hospitallers to add a military wing to their organization in the late 1120's or early 1130 's, and to join the Second Crusade in 1147. On the other hand, they acquired no castles until the late 1130's, when they appear to have occupied existing fortresses for the Franks. They were sparsely represented in the ranks of the Frankish armies

12 Elena Lourie, "The Will of Alfonso I, "El Batallador," King of Aragon and Navarre: A Reassessment," Durham University Journal 50 (October 1975), 645-6. Barber supports Lourie's theory that Alfonso had ulterior motives (See Malcolm Barber, The New Knighthood, 27-8). This view remains controversial, however. See A.J. Forey, "The Will of Alfonso I of Aragon and Navarre," DUJ, 73 (December 1980) and Lourie, "The Will of Alfonso I of Aragon and Navarre: A Reply to Dr. Forey," DUJ 77 (June 1985), 173 for Forey's argument that Alfonso's will should be taken at face value.

13 Elena Lourie, "The Will of Alfonso I of Aragon and Navarre: A Reply to Dr. Forey,"170-2. 
before the Second Crusade, and we know little about their military activities before that date. Why?

The most likely answer is that the nature of the earliest Templars' duties in Palestine made them a more mobile and disciplined group than the Frankish military forces. The Templars' original purpose was "that, as far as their strength permitted, they should keep the roads and highways safe from the menace of robbers and highwaymen, with especial regard for the protection of pilgrims." 14

Bandits infested Latin Palestine during the first half of the 12th century. The usual feudal strategies of war (castles, sieges, and armored cavalry charges) were useless against such marauders. They were also extremely expensive. Standard Turkish tactics (which were adopted by Muslim armies throughout the region) were to use fast, mounted archers, who harried and retreated continuously. 15 Such methods perfectly suited the needs of impoverished bandits in mountainous country.

The Templars soon learned how to counter such attacks without wasting valuable resources. Later European chroniclers often criticized the Order for the caution that the Templars acquired during this period. Clearly, the Templars had not derived their traditional tactics from European military theory. They had to have discovered them through experience and observation in fighting, first, Muslim raiding parties, then Muslim armies. That they did arrive at their successful tactics through trial and error can be seen in their notable lack of success in their initial encounters with large Muslim forces. By the Second Crusade, however, they had become experts at thwarting Turkish harrying tactics.

14 William of Tyre, A History of Deeds Done Beyond the Sea, vol. 1, 525.

15 R.C. Smail, Crusading Warfare, 1097-1193, 2nd ed., (Cambridge: Cambridge University Press, 1995), 75-83. 
The very first thing the Templars learned was discipline. Medieval European armies were not noted for this quality. Even the heavy cavalry charge, which was nearly unstoppable when properly organized and aimed, often failed to reach its target. Knights became confused, fled in fear, gave in to rage and broke ranks, or turned aside to pursue booty.

Sometime early in the Order's history (possibly as early as the 1120's) the Temple forces developed a standard (the confanon baucon--Piebald Banner) around which they rallied in battle. Their war cry (Beauseant, or Bauçeant) probably derived from this standard, which was a square, two-toned ( black and white) cloth.16 Some believe that the banner represented the Templars' dual nature--black and deadly to their enemies, white and gentle to their friends. This derives from Jacques de Vitry's metaphor of them, in his History of Jerusalem, as: "lions in war and gentle as lambs at home; in the field they were fierce soldiers, in church they were like hermits or monks; they were harsh and savage to the enemies of Christ, but kindly and gracious to Christians."17 Such a fanatical image would generate European criticism against the Templars whenever the Order made treaties with Muslims, or otherwise showed them mercy. 18

Another aspect of this discipline was the prohibition in the Rule (\#161) against breaking ranks, either on campaign or in battle. If a Templar broke this regulation, he was publicly humiliated and lost the use of his horse. This, along with daily periods of enforced silence (\#157), and an intricate hierarchy of small groups, helped form quiet, well-regulated soldiers who almost never

${ }^{16}$ The Rule of the Templars: The French Text of the Rule of the Order of the Knights Templar, trans. J.M. Upton-Ward, vol. 4, Studies in the History of Medieval Religion (Woodbridge: The Boydell Press, 1992), 178 (Rule \#99-100).

17 Edward Burman, The Templars: Knights of God (Rochester: Destiny Books, 1986), 59. 18 Helen Nicholson, Templars, Hospitallers and Teutonic Knights: Images of the Military Orders, 1128-1291 (Leicester: Leicester University Press, 1993), 43-8. 
lost their heads in battle the way ordinary knights did. 19

The other vital thing which the Templars learned from fighting the Muslims was maneuverability. In order to stay mobile they had to have good horses, and many of them. They learned this lesson very early. During his fundraising trip to Europe in 1129, Hugh de Payens, first Master of the Templars, arranged the transport of horses as well as troops to Palestine.20 The Templar Rule is filled with affectionate references to horses. They were the single most important piece of the Templar's equipage, be he knight or sergeant. The importance of the horse is born out by the anecdote Odo de Deuil tells that during Louis VII's trek through Asia Minor during the Second Crusade, the Templars starved themselves to keep their horses alive. A Templar without a horse was not a Templar.21 Because they retained their tactical mobility, the Templars successfully reorganized Louis VIl's army, under constant Turkish harassment, during the Second Crusade.

The early Templars probably earned their veteran status in their wars against their first enemies, the petty bandits. They must have eliminated this threat, or brought it under control, by 1148. Otherwise, they could not have fielded such a strong presence during the Second Crusade.

While Muslims did continue to raid Latin Palestine after the 1130's, these attacks were military, rather than piratical, in nature. This change reflects the Templars' success in reducing banditry in Christian territory. In 1172, Theodorich, a German monk, noticed that the Templars exercised a strong

19 Matthew Bennett, "La Règle du Temple as a Military Manual, or How to Deliver a Cavalry Charge," in Studies in Medieval History Presented to R. Allen Brown, ed. Christopher HarperBill, Christopher J. Holdsworth, and Janet L. Nelson (Woodbridge: The Boydell Press, 1989), 13-15.

20 John H. Pryor, "Transportation of Horses by Sea During the Era of the Crusades. Part I," The Mariner's Mirror 68, no. 1 (1982): 15.

21 Malcolm Barber, The New Knighthood, 94. 
military presence throughout Latin Palestine. In addition to their castles, they maintained garrisons and pilgrim hostels all over the region--especially near important Christian shrines. They also patrolled the pilgrim roads, such as the route from the port of Jaffa to Jerusalem. 22 This indicates that the Templars expanded their operations to include military campaigns, rather than abandoning their original commitment to protecting pilgrims to build their military strength. They may have recognized that, in order to secure the safety of Christian pilgrims, it was necessary to expand the borders of Latin Palestine. Or, they may have been drafted into service as one more organized military band in the region by the local nobility.

\section{Success}

That the Templars were successful in their initial mission is shown by their quick acceptance into the main body of the Church. By making the Temple a monastic order, the Church brought a dynamic, but also dangerous and potentially heretical group back into its fold. The combination of priest and warrior unnerved many clerics. Also, other lay Christian groups had turned heretical in the past. As knights and lay canons, the Templars' allegiances and their position inside the feudal hierarchy of the Kingdom of Jerusalem were questionable. From both a religious and political standpoint, they were too independent.

At the Council of Troyes, in 1129, the Templars attained orthodoxy. There, they were accepted as an official monastic order and given a rule based on

22 Theodorich, Guide to the Holy Land, trans. Aubrey Stewart, 2nd ed., (New York: Italica Press, 1986), 22, 46-8, 86. 
the Cistercians' Benedictine Rule. No schism occurred inside the Order following this decision such as occurred within that of the Franciscan Order in the late 13th century. Presumably, the Templars had made the decision within their own ranks beforehand. The Templars presented a remarkably united front to the outside world throughout their history--even during their Trial.23

Official recognition was critical for the new order. Without it, they would have quickly suffered the fate of the Waldensians and the Cathars. In the beginning, these two sects were part of the laity within the Church. Eventually, they either left, or were expelled from, the Church. The Church then condemned them as heretics.

The idea of the military order, begun by the Templars, was originally a solution to local conditions on the Christian frontier.24 When this frontier closed, the heterodox aspects of the concept became all too clear. This problem would not become fatal for the Templars, however, until after the fall of Acre to the Muslims in 1291.

Certainly, the Templars could not have acquired their holdings, and exploited them relatively unmolested (Templar immunity from local interference was always total only in theory), without Church sanction.25 Following the Albigensian Crusade against the Cathars in the early 13th century, medieval society became far less tolerant of groups that did not

23 After the initial shock and confessions, about 100 hundred French Templars were able to organize a defense against their accusers in 1308. All of the defenders were of sergeant's rank, or lower. Yet, they showed the same corporate pride and esprit de corps as the more celebrated knights--who did not defend themselves. It took the mass burning of 54 "relapsed" Templars in 1310 , and the isolation of the rest from their leaders and each other, to break the prisoners' resistance; Malcolm Barber, The Trial of the Templars (Cambridge: Cambridge University Press, 1978), 122-153.

24 Aharon Ben-Ami, Social Change in a Hostile Environment: The Crusaders' Kingdom of Jerusalem (Princeton: Princeton University Press, 1969), 64-71, 140-1, 182-5.

25 Alan Forey, "The Military Orders, 1120-1312," in The Oxford Illustrated History of the Crusades, Jonathan Riley-Smith, ed. (Oxford: Oxford University Press, 1995), 201. 
remain inside very specific boundaries. The lawyers of Philip the Fair exploited the uneasiness that had existed since the Council of Troyes with the idea of mixing the two orders of knights and clergy--and of giving a monastic order complete immunity from local clerical influence. This led to the downfall of the Templars.

As the Templars grew in power and stature, they had acquired a monastic rule, headquarters on the mount of the Temple of Solomon, and lands and rights all over Europe. Small wonder that they were soon accused of arrogance and avarice. In fact, the Templars may have remained credit-rich, but cash-poor, throughout their time. Most of their wealth rested on their banking and credit operations. This forced them to periodically disgorge large sums of money to powerful debtors (kings and high nobles) who were unlikely to pay them back. 26

\section{Cluny and Citeaux}

Originally, coenobitical (living in groups) monastic societies had been small and eccentric--consisting of desert communities of hermits living near by to each other, but isolated in separate cells. As coenobitical religious life became more popular than hermetical (living alone) life, people developed a need for order in these small societies. Hermits never quite went away, but they dwindled to a silent minority in the Christian monastic community. 27

One of the earliest (and most successful) Rules was developed by St. 26 D.M. Metcalf, "The Templars as Bankers and Monetary Transfers between West and East in the Twelfth Century," in Coinage in the Latin East: The Fourth Oxford Symposium on Coinage and Monetary History, ed. P.W. Edbury and D.M. Metcalf, B.A.R. International Series, no. 77 (Oxford: B.A.R.: 1980), 1-17.

27 C.H. Lawrence, Medieval Monasticism, 1-7. 
Benedict. Benedict was an early 6th century Italian abbot of a small monastery on Monte Cassino. Wishing to moderate the extreme asceticism of some contemporary communities, Benedict set down the already basic and generally accepted requirements of the coenobitical ascetic life (poverty, and chastity) and added obedience to the abbot, who ran the community. Despite competition from far more rigorous Rules (such as that of the Irish abbot, St. Columbanus), Benedict's Rule eventually became the standard set of regulations for monastic communities. 28

The Benedictine community came to be known as the Cluniac model of monasticism--based on the Benedictine Rule as used at the convent of Cluny in France. This model was characterized by considerable ritual. Cluniac monks usually hid away in their cells, coming out several times a day to chant prayers at Mass. They frequently served as spiritual advisors to the rich, while increasingly disconnecting themselves from the poor. By the 11th century, many people had become dissatisfied with the rigid structure of the Cluniac model and sought reform within the monastic system. Medieval Christianity was a fundamentalist society in the sense that adherents (both orthodox and heretical) saw the universe in stark terms of good and evil, rejected the material and secular aspects of their society, and frequently attempted to institute reforms that would return the faith to an idealized past, or bring about the anticipated Kingdom of Heaven.29 This was especially so between the

\section{Ibid., 20-5.}

29 Niels C. Nielsen Jr. , Fundamentalism, Mythos, and World Religions (Albany: State University of New York Press, 1993), 8. See also, Lionel Caplan, Studies in Religious Fundamentalism (Albany: State University of New York Press, 1987), 5, 17. Caplan sees fundamentalism as a modern phenomenon, but his concept of the fundamentalist "ahistorical world view" (pg. 17) of sacred texts aptly describes medieval Christian views of the Bible. For fundamentalism's trademark rejection of the corrupting World, see Lawrence Kaplan, Fundamentalism in Comparative Perspective (Amherst: The University of Massachusetts Press, 1992), 7. Chapter three will explore the rise of Muslim fundamentalism under the Crusaders and how Christian fundamentalism fueled the Reconquista against the Muslims in Spain. 
11th and 14th centuries--the heyday of the Crusades and the military orders:

In the late 11th century, monastic reformers dissatisfied with the Cluniac system decided to go out into the wilderness and practice true poverty there by cultivating the earth themselves. Basing their new order on the model of a convent at Cîteaux, these reformers became known as Cistercians. 30 They paved the way for the Dominicans and Franciscans--who practiced poverty in the cities instead of the wilderness.

The paths of the Cistercians and embryonic Templars crossed in the person of St. Bernard of Clairvaux. Bernard was the most famous churchman of a century that experienced a religious renaissance not seen since the reign of Charlemagne. He had already raised the Cistercians to greatness with his preaching when he encountered the Templars. He was a master propagandist--mostly because he believed everything he said, however contradictory.

Bernard's interest in the Templars came from related sources. First, his cousin was Hugh de Payens, the leader (and first Grand Master) of the Templars. Second, Bernard had close ties to Hugh de Champagne, his liege lord, who was also Hugh's lord. Third, he came from a proud family of knights-his brothers all followed this vocation. His dress and vocation were of the clergy, but his ideals and mentality sprung from the knightly class of his birth. Bernard combined intense spiritual faith with the aggressiveness of a knight. Too sickly to become an earthly soldier, he determined to become a heavenly one instead. He was fascinated with the concept of the spiritual warrior. The Templars, when they came to his attention in the early 1120 's, fired his imagination in a way that neither monks nor knights, alone, could. 31

30 C.H. Lawrence, Medieval Monasticism, 126-7.

31 G.R. Evans, The Mind of St. Bernard of Clairvaux (Oxford: Clarendon Press, 1983), $24,35$. 
Bernard became aware of the Templars because of the goodwill that had grown up around their cause. He would never have been able to manufacture their popularity out of whole cloth. He was attracted to their military mission, which was carried out in an atmosphere of real poverty. For a Cistercian reformer, this voluntary penury combined with a lifelong willingness to die in the battle for Christ would have increased the Templars' sanctity to the level of martyrdom. Despite Bernard's rhetoric in In Praise of the New Knighthood, however, no individual Templar was ever canonized. Personal martyrdom was absorbed into the corporate image.

\section{Holy Warfare}

In a moment of historical serendipity, this odd and possibly heretical experiment answered an inarticulate need for a religious dimension in warfare that still resonates today. Following the collapse of the Carolingian Empire in the 9th century, Christian Europe had wrestled with increasingly senseless and uncontrollable violence. Muslim and Viking invasions during that time caused internal disintegration that eliminated all centralized power. By the 11th century, knights--even kings--had become indistinguishable from brigands.

External attempts to regulate the carnage--the Peace of God, the Truce of God, holy protection through saints' relics, sanctuary on holy ground, and the concept of trifunctionality--had found distinctly mixed success. The Peace of God stipulated that noncombatants (Clerics, merchants, women and children) were to be exempted from harm. The Truce of God limited fighting to only a 
few days per week.32 Saints' relics were used as a deterrent against pillage; a powerful saint was believed to take revenge on anyone who desecrated his or her shrine. People also swore oaths upon relics (an old Germanic custom), incurring the saint's wrath if they broke their word. 33

The theory of trifunctionality divided medieval society into three interdependent Orders: those who prayed, those who fought, and those who worked. The first Order (the clerics) provided eternal salvation to society, the second Order (the knights) provided protection from earthly perils. The third Order (the peasants) fed and clothed everyone else.34 This theory remained an ideal more than reality for the duration of the Middle Ages. It did, however, shape how medieval people saw themselves and justified their actions.

The above experiments reflected the lack of law and order in the 11th century that the loss of centralized, secular power had caused. Urban II has not left his personal reasons, only his public ones, for calling a Crusade. Historians now believe, however, that one of Urban's greatest reasons for doing this was to rid Europe of its most chaotic elements by inflicting them upon the Muslims. 35

In the Templars, the knights offered a solution themselves--fighters acting as swords of Christ who would fulfill the knight's idealized function of societal protector by following established monastic principles. During the First Crusade, this new ideal was only partially articulated--and even more imperfectly followed. It did not prevent the Crusaders from raping, murdering,

32 Georges Duby, The Three Orders: Feudal Society Imagined, trans. Arthur Goldhammer (Chicago: The University of Chicago Press, 1980), 134-9.

33 Patrick J. Geary, Furta Sacra: Thefts of Relics in the Central Middle Ages (Princeton:

Princeton University Press, 1978), 37-8, 56.

34 Georges Duby, The Three Orders, 6, 101.

35 Marcus Bull, "Origins," in The Oxford lllustrated History of the Crusades, 31-3. 
looting, and cannibalizing their way through the lonian peninsula. 36 But, it was at least an ideal, finally, that the knights accepted.

The Templars' innovation was to devote themselves to the ideal of holy knighthood permanently, and to form a disciplined core of fighters living out the ideal. In the process, they built up a military organization that echoed the ideals of the modern military more than the code of the medieval knight. Since the early leaders of the Temple were all veterans of the First Crusade, this side effect was probably deliberate.

Bernard wrote In Praise of the New Knighthood to promote the Templars. This treatise painted a crypto-manichaean world where Christian warriors battled the forces of darkness. One of the most important concepts in the work was that of malicide. This was the concept of killing people, simply because they did not believe in Christ, and being blessed by God for it. 37 Bernard engineered the Templars' formalization as a monastic group at the Council of Troyes in 1129.

There, a clerical committee, led by Bernard, presented the Templar Rule. This was the new Order's official acknowledgment by the Church. This Rule was based on the Benedictine Rule used by the two major monastic groups of the time, the Cluniacs and the Cistercians. It was later translated into French, and expanded, from the 1140's onward, to meet the needs of the expanding order.38

36 Amin Maalouf, The Crusades Through Arab Eyes, trans. Jon Rothschild (New York: Schocken Books, 1984), 39.

37 St. Bernard of Clairvaux, "In Praise of the New Knighthood," in The Works of Bernard of Clairvaux: Treatises 3 , vol. 7, trans. Conrad Greenia (Kalamazoo: Cistercian Publications Inc., 1977), 134.

38 The Rule of the Templars, trans. J.M. Upton-Ward, 11-13. 


\section{The Rule}

The initial Latin Rule, and its companion piece, In Praise of the New Knighthood, was public. Later translations and revisions were not. During its first translation, in the 1140's, the Rule was removed from the public eye and revised, from then on, only within the Order. Even within the Order, only Bernard's treatise and the original rule were freely circulated. This change has contributed to the theories that the Templars were a secret group of sorcerers, or heretics. 39

Evidence from the Rule does not bear this out. The most likely reason for secrecy was military security; most of the changes involved specific military tactics and infrastructure. The Templars probably feared that making the Rule public might reveal to the Muslims too much of their thinking in battle. Ironically, this fear may have been exaggerated--Muslims showed little interest in European culture.

It was also during this time that a controversial change in the Rule--one that would have created great scandal if it had been known outside the Order-was made. The regulation enjoining the members to recruit only among nonexcommunicated knights was changed to exhorting brothers to recruit specifically from among excommunicated knights. 40 Historians have noted. that the Temple was so desperate for members that it was willing to take in many of the criminals who had been flocking to the Holy Land since the First Crusade had opened up the region to European colonization. 41 The Templars so successfully absorbed these unruly elements that outside authorities sometimes sentenced great criminals who were too influential to kill (from

39 Ibid., 10. See also Malcolm Barber, The New Knighthood, 184.

40 The Rule of the Templars, trans. J.M. Upton-Ward, 13, 22 (Rule \#12).

41 Christopher Tyerman, "Who Went on Crusades?" in The Horns of Hattin, ed. B.Z. Kedar, (Jerusalem: Yad Izhak Ben-Zvi, 1992), 21-2. 
murderers to embezzlers) to join the Order. Since membership in the Temple was lifelong (even expelled members. were not released back into the community, but were imprisoned, instead) this was a life sentence. 42

The Rule of the Templars survives in a small collection of manuscripts. The Latin Rule is most prevalent. Because it was public, it did not need to be hidden, or destroyed, when Philip's officers made their arrests. Of the others, the earliest (an early 13th century manuscript from Dijon) contains only the first two sections of the Rule (the Latin Rule and the Hierarchical Statutes). Two other, more complete, copies date from as late as the early 14th century. They probably derive from the same original manuscript. Only one regional version (a Catalan copy of the retrais--Hierarchical Statutes) survives. The Grand Master of the Order, Jacques de Molay, ordered all manuscripts of the Rule recalled and burned shortly before the arrests in 1307. The lost parts of the Rule probably discussed military tactics rather than heretical or sorcerous practices. While what parts we have refer frequently to now lost military statutes, the same regulations show a marked distaste for anything resembling the contemplative life.

The original Latin (or Primitive) Rule, drawn up at the Council of Troyes by a committee of clerics, consisted of 76 statutes. In some ways, these statutes reflected the de facto regulations which the Templars had been living by for the past decade. Most of them, however, ignored the Templars' military role and focused on their conventual life. Because of this new Rule, the Templars gained many privileges, but lost others. They had previously taken on some priestly duties, such as baptism, which were now forbidden to them (\#72). With the Temple's renunciation of these duties, heresy was avoided and the 
new Order's monastic role was clarified. 43

The rest of the Rule, as it has come down to us, is somewhat chaotic in organization. The next four sections, Hierarchical Statutes, Penances, Conventual Life, and the Holding of Ordinary Chapters, all date from the middle of the 12th century, before Saladin's campaigns. The last two sections: Further Details on Penances, and Reception into the Order, date to the mid13th century. 44

The second major portion of the Rule, the Hierarchical Statutes (\#77-223), comprises the largest section of the statutes. These statutes concern themselves with the infrastructure of the Order. The last 26 statutes of this section discuss the transfer of power following a Master's death. Conventual Life (\#279-385) regulates daily life within the Order--in the convent, on campaign, and in battle.

The Penances (\#224-278) discuss the grounds for expulsion (\#224-232) and for the temporary loss of one's habit (\#233-266). They also give a brief description of an initiation ceremony (\#274-278).

Nine offenses led to expulsion: simony (\#224), disclosure of the affairs of a Chapter (\#225), killing, or allowing the death of, a Christian man or woman (\#226), theft (\#227), leaving a fortified place by any way save the gate (\#228), conspiracy (\#229), desertion to the Muslims (\#230), heresy (\#231), and abandoning the Beauseant, in battle, to the Muslims (\#232).

Thirty-one offenses led to a loss of habit for a year and a day: Disobedience of a house commandment, striking another brother, striking a

43 This early, priestly role of the Templars reflects a dearth of Latin clerics on the Palestinian frontier. Since the Templars were willing to give up this role for monastic legitimacy, it seems unlikely that they were intentionally heretical. Other heretical groups, such as the Cathars, took on sacerdotal duties in the absence of an adequate Latin priesthood. They, however, refused to relinquish these duties upon demand.

44 The Rule of the Templars, trans. J.M. Upton-Ward,11-16. 
Christian--man or woman, sleeping with a woman or entering a brothel, slander against another brother, slandering oneself in order to be expelled from the Order, trying to enter another religious order without permission, threatening to desert to the Muslims, lowering the Beauseant in battle, leading a cavalry charge without permission (for brothers who jumped the gun while carrying the Beauseant), charging into battle without permission, refusing food or entry into camp to another brother, giving away one's habit without permission, taking bribes for entry into the Order, breaking the seal of the Master (i.e. reading his correspondence), breaking a lock, giving alms to anyone outside the Order, lending out belongings of the Order, lending one's horse to another brother, illegally appropriating someone's possessions for the Order, lying about said possessions, killing, injuring, or losing a slave, doing the same with a horse, causing a hunting accident, causing an accident during arms practice, giving away any animal save a dog or cat, building a house, deliberately causing the Order to lose at least four deniers, fleeing the Order (only if a brother repented did he escape expulsion), leaving a house of the Order for at least two nights, and tearing off and throwing down one's habit in anger.

In Conventual Life, rule \#328 (leaving a fortress in secret) was subsumed into the general rule for theft (\#327). Sodomy was added to the list of offenses punishable by expulsion.

In general, the Templars despised theft, lying, cowardice in battle and desertion (or betrayal) to the Muslims as the greatest offenses against the Order. Theft was treated with special contempt. Damaging property and simony both fell under theft. Offenses involving money and property merited such severe censure that a brother found dead with money on his person was 
buried outside holy ground like a slave (\#331), and a brother could also lose his habit for injuring a slave or a horse.

Lying, particularly upon entry to the Order, was also a very serious offense. A free bastard could enter the Order as a sergeant, but not if he lied about his legitimacy and tried to enter as a knight (\#435-436). The Templars showed compassion to sick (\#439) and elderly (\#338-339) brothers, and even those suffering from leprosy (\#443) or madness. 45 Leprosy and insanity were common occupational hazards for a soldier in 12th and 13th century Latin Palestine. If a brother lied about his illness upon entry, however, he could be expelled (\#438).

The Templars were different from other monks in several ways. Women could not join the Temple (\#70), nor could the Order take in child oblates (\#14), except under exceptional circumstances.46 Because they needed to be physically fit for battle, the brothers of the Temple were allowed to eat meat much more often than other monks (\#184-186). Asceticism was discouraged (\#15).

The two basic groups of the Order were the knights and the sergeants. After the papal bull Milites Templi was issued in 1144, the knights wore a white habit with a red cross on the front. Sergeants wore the same design in brown. At least some of the sergeants made up an infantry. They also conducted the banking functions of the Order, could command ships in the Templar fleet, and could run Houses which did not contain knights.

45 In the Catalan Rule, the possessed and the insane were treated as separate categories. The latter were confined in chains. The Rule may simply have been making the distinction between non-violent and violent cases of madness; Malcolm Barber, The New Knighthood, 218. 46 Sometimes, nobles placed their teenaged sons with the Order for military training; Malcolm Barber, The New Knighthood, 214. The Temple might also take in widows and orphans if they were related to the Order in some way. Roger de Flor's family survived due to Templar charity, despite the fact that his father had been a vassal of their enemy, Frederick II; Moncada, Francisco de, The Catalan Chronicle of Francisco de Moncada, trans. Frances Hernández, ed. John M. Sharp (El Paso: Texas Western Press, 1975), 11-12. 
The Temple also kept a group of light cavalry--local, Syrian troops, called Turcopoles. They were led by a knight, the Turcopolier, who was a highranking member of the Order. There were also servants and craftsmen, serfs and slaves. In Palestine, some of the servants and craftsmen were Muslim slaves. Those members who were free, however, considered themselves brothers of the Order.

Conventual houses were run by Commanders. Preceptors generally ran entire regions but they might also administer important fortresses. The two terms were often used interchangeably. At the top of it all was the Grand Master. In theory, he ruled absolutely. In practice, he was a constitutional monarch. He could not make major decisions without consultation with the Chapter (the Marshal, the Seneschal, the Draper, and the five Commanders of the cities of Jerusalem, Acre, Tripoli, and Antioch--and of the Kingdom of Jerusalem). European commanders were also technically part of the Chapter, but exercised little influence in it. The Grand Master was chosen by a council elected after the death of the previous Grand Master. A Grand Commander was elected by the council to oversee the proceedings. In the event of the Grand Master's death, or his absence, the Marshal ran the Order.

\section{Success and Conflict}

Following their acceptance into the Church, the Templars rose rapidly in power and prestige. Their first major action occurred during the Second Crusade (1148-9). This Crusade, which was preached by St. Bernard, was neither well-planned nor well-executed. It included both the King (Louis VII) 
and Queen (Eleanor, Grand Duchess of Aquitaine) of France--as well as King Conrad of Germany, who began on friendly terms with the Templars, but ended as their enemy. Louis suffered considerable losses and debts on his way to the Holy Land. Historians, then and now, generally credit the Templars--who served as Louis's rear-guard on his journey to Palestine--with saving

the Crusade from becoming an unmitigated disaster. They reorganized Louis' army under Templar commanders, and thus got it intact to Palestine despite frequent Turkish attack. 47

The Crusade's objective was to take Damascus. It failed. The crusaders besieged the city, but were unable to take it. They were eventually forced to retire. Conrad and his retinue then spread a rumor that the Templars had accepted a bribe from the ruler of Damascus to force a retreat. 48 After his previous friendship with them, Conrad's attack on the Templars caused some bitterness among the members of the Order.

The truth of Conrad's rumor seems unlikely. First, there is no other evidence than Conrad's accusation that the Templars took such a bribe. Nor is there any motive they might have had for taking it. Second, it was standard practice for the group most blamed by public opinion for the failure of a crusade to try and deflect its guilt onto another party through slander. If the Templars did engage in this tactic, we have no surviving examples of it. On the other hand, they were a favorite target for others using the tactic. 49 Even

47 Malcolm Barber, The New Knighthood, 67; Barber takes the story from Odo de Deuil's De Profectione Ludovici VII in Orientem. See also A.J. Forey, The Military Orders: From the Twelfth to the Early Fourteenth Centuries (Toronto: University of Toronto Press, 1992), 88.

48 Ibid., 68-70.

49 M.R. Morgan, The Chronicle of Ernoul and the Continuations of William of Tyre (Oxford: Oxford University Press, 1973), 64. The Ibelins leveled similar accusations against the Templars after the family's head, Raymond of Tripoli, was accused of allying with Saladin and engineering the massacre of Hattin in 1187. 
this early, some perceived the Templars as splitting their allegiances between the Franks and the local Muslims. These accusations in large part, stemmed from jealousy and diversionary measures by treacherous local Franks and incompetent European leaders. Like Usamah's portrait of his "friends, the Templars,"50 however, they indicate that the Templars assimilated early, and deeply, into the local Arab culture.

Damascus was not a goal which the Crusaders would pursue in the future. The Third Crusade's purpose was to drive back Saladin and retake Jerusalem. It eschewed the latter to achieve the former. Saladin's death secured the rest. Crusades in the 13th and 14th century concentrated on conquering Egypt, by way of Damietta. The Franks--especially the Templars-recognized the importance of depriving their Muslim enemies of the Egyptian bread basket. 51 They were also turning their attention away from the view of Palestine as the Holy Land, and more toward the view of it as the frontier territories called, collectively, Outremer.

It was during the Papal preparations for the Second Crusade that the Order received its distinctive uniform--white garb with a red cross on the chest.52 Before that, they had had no distinctive garb, nor any great distinction in rank. After Milites Templi was issued, standardization within the Order accelerated.

After the Second Crusade, the Franks in the Holy Land were regarded with increased suspicion by Europeans back home. This was partly due to Conrad's chroniclers, whose accusations stereotyped all Latin Palestinians, not just the Templars. Europeans back home felt (probably correctly) that the

50 Usamah Ibn Munqidh, An Arab-Syrian Gentleman and Warrior in the Period of the Crusades: Memoirs of Usamah Ibn-Munqidh, trans. Philip K. Hitti, (New York: Columbia University Press, 1929; reprint, Princeton: Princeton University Press, 1987), 163 (page references are to reprint edition).

51 Malcolm Barber, The New Knighthood, 126.

52 William of Tyre, A History of Deeds Done Beyond the Sea, vol. 1, 525. 
Palestinian Franks, who had few ties remaining in Europe, had become

assimilated into the local culture and were more interested in carving out their niches within that local culture than in eliminating it. 53

Also, the atmosphere between Christians and Muslims had soured. Initially, the Muslims had been too divided to respond to the new invaders with any unity of hostility. In theory, it may have been more galling to have Christians taking over Arab land than to be invaded by Muslims, or pagans who converted quickly to Islam. However, the destructiveness of the Crusades did not approach the devastation caused by the invasions by Central Asian tribes, which began in the 10th century and continued until the Ottoman Turks consolidated their empire in the 15th century.

Relations between the Templars and the Muslims were good enough before the Second Crusade to prompt favorable mention by some Arab chroniclers. Usamah Ibn Munqidh used an incident in which veteran Templars interceded when a new recruit attacked him to show that the Templars were among the minority of Europeans who had assimilated into local Arab culture (In Hitti's translation, Usamah uses the word "civilized.").54

Beginning with Zengi, Atabeg 55 of Mosul in the 1130's, then continuing

53 Desmond Seward, The Monks of War: The Military Religious Orders, 2nd ed., (London: Penguin Books, 1995), 24.

54 Usamah Ibn Munqidh, An Arab-Syrian Gentleman and Warrior in The Period of the Crusades, 163-4.

55 The title, "Atabeg" [prince-father], is of Turkish origin. Like the Carolingian Mayors of the Palace, the original atabegs were bodyguards to the Seljuks. They later took power as princes, themselves; Amin Maalouf, The Crusades through Arab Eyes, 281. "Sultan" derives from Medieval French and Greek forms, which themselves derive from Medieval Arabic. Its original meaning was simply "ruler in a Muslim country." It acquired a later connotation, that of tyrannical rule, from the 15th century with its use by the rulers of the Ottoman Empire. "Caliph" also means ruler, but has religious connotations as well. The original Caliph, Omar, was Muhammad's successor as leader of the 'umma (the first Muslim community under the Prophet). Thus, the Caliph was a religious, as well as a political ruler. Originally, there was only supposed to be one Caliph. Later rivals for the position set up their own kingdoms. See The Compact Edition of the Oxford English Dictionary, (Oxford: Oxford University Press: 1971; reprint, 1984) vol. 1, 319, for "Caliph." See OED, vol. 2, 3149, for "Sultan." 
with Nur-ad-Din, his son, and culminating in Saladin, Nur-ad-Din's successor, who took power in 1176 and terrorized the Crusaders until his death in 1193, a Muslim campaign to expel the Crusaders went on for 60 years. It culminated in the disaster at the Horns of Hattin in 1187, the loss of Jerusalem, and the Third Crusade.

Meanwhile, in the 1150's and 1160's, the Templars came into conflict more often with the King of Jerusalem and the other Frankish nobles than they had before. During the successful siege of Ascalon in 1153, they were accused of sabotaging the Frankish cause. Shortly before the city fell, the Templars discovered, and took advantage of, an unexpected breach in the city walls. William of Tyre (Arab sources do not mention the Templars in siege accounts) accused the Templars of holding the breach against the Franks so as to claim more of the booty in the city. The Templars, unable to hold the breach, were massacred. Their bodies hung on the city walls the next day. Ascalon did not fall for another week. 56

Because of William's hostility toward the Order, it is difficult to parse out the meaning of this incident. Also, he was working from second-hand information in this particular incident; he was not in Palestine, at the time. Did the Templars really try to hold the breach against the rest of the Christians, or were they trying to hold it for them? Considering the usual disarray in battle of a Christian army in the best of times, the confusion of the Christians at such an unexpected opportunity must have been great. In the event of a failure to take advantage of such a breach, and, consequently, leave its defenders to their deaths, their embarrassed comrades may have made up a story of treachery (and even believed it) to cover their own shame. After all, who would contradict them, since all of the defenders were dead? On the other hand, the 56 William of Tyre, A History of Deeds Done Beyond the Sea, vol. 2, 227-223. 
Templars may have been motivated by a recent Papal bull which ceded them the spoils of whatever booty their troops seized in a siege. 57

In 1154, the Templars captured a man called Nasir al-Din. He was the son of the Egyptian caliph's vizier. The vizier had murdered the caliph in hopes of bringing his own son the throne. Nasir (whether genuinely or not) tried to save himself by converting to Christianity while in Templar captivity. The Templars sold him back to Egypt, where he was elaborately executed.58 The source of this story, William of Tyre, relates another tale as well (this time of the leader of the Assassins) in which the Templars kill a Muslim after he attempts to convert. It is one of William's motifs. Whether it was a habit of the Templars to kill Muslim apostates or whether William's hostility toward the Order led him to repeat himself is unclear. The repetition is suspicious, however.

William did not always disagree with the Order. Fifteen years after Nasir's execution, the Templars refused to take part in an invasion of Egypt because they had a treaty with the treasonous vizier's successor, Shawar.59 They seem to have had no objections to raids on Egypt, or intrigues within the Egyptian court (hence the treaty). They did object, however, to openly breaking a treaty with a Muslim ally. In this case, William agreed with them because he, too, disapproved of breaking a treaty--even if such an action were advantageous to the Franks. It would not be the last time that the Templars would eschew a possibly successful attack for the Christians in

57 Malcolm Barber, The New Knighthood, 73-5.

58 William of Tyre, A History of Deeds Done Beyond the Sea ${ }_{1}$ vol. 2, 252-3. Walter Map, De Nugis Curialium [Courtiers' Trifles], trans. M.R. James (Oxford: Clarendon Press, 1983), $62-7$. Desmond Seward, The Monks of War, 47-8. William asserts that Nasr was thrown to the Egyptian mob. Walter Map insists that Nasr was a martyr to Christendom. He claims that Nasr was tied to a stake and shot full of arrows, in imitation of Saint Sebastian and Saint Edmund of East Anglia. Seward relates a story that Nasr was castrated by the murdered Sultan's wives and then crucified upside down, like Saint Peter. He also claims that Nasr had been the Sultan's homosexual lover. He does not, however, supply sources for either of these stories.

59 Malcolm Barber, The New Knighthood, 96. 
favor of honoring a treaty that they had made with a Muslim ally. Their attitude would make them enemies. This time, it made an enemy of the King of Jerusalem, Amalric, who had devised and led the attempted invasion of Egypt in 1169.

Amalric believed in the absolute authority of his office. He resented the independence of the Orders, and did his best to limit their power during his reign. He had pushed through his own candidate, Philip of Nablus, for election as Grand Master of the Temple in 1169. He repeated this maneuver in 1171, by promoting Eudes de Saint-Amand upon Philip's death. Apparently, Amalric had hoped to control the Order through his own handpicked Grand Masters. De Saint-Amand's subsequent refusal to compromise the Orders interests for his former liege-lord's pleasure is the probable source of William of Tyre's accusations of pride and treachery, since Amalric was William's patron.

As Malcolm Barber notes, Amalric was not alone in his ambitions against the Church and concerns about ungrateful clerics. While Amalric fought the Templars, King Henry II of England and the Archbishop of Canterbury, Thomas à Becket, were engaged in a deadly struggle for power over the Church in England. Becket, a personal friend and vassal of Henry's, had been appointed to the office by the King. When he later took the side of Rome in Church matters, Henry felt betrayed. Henry eventually provoked Becket's murder, and was forced to do penance for it by the Pope.60

In addition to their refusal to join his attack on Egypt, the Templars provoked two other incidents with Amalric. The first, the surrender of a castle in

60 Ironically, the Temple became involved in the mediation with the Pope over Henry's penance for Becket's murder. As a substantial patron of the Order in England, Henry agreed to deposit money in the Temple treasury as part of his punishment. Gerard de Ridefort eventually used this money to fund the disastrous campaign at Hattin. Henry did not object. See Malcolm Barber, The New Knighthood, 100, 107, 112, 278. 
Oultrejourdain (the French term for the area "beyond the river Jordan") to Nurad-Din by Templars, appears to have occurred in 1166. The chronicler, William of Tyre again, is vague about details. He does note, however, that Amalric had twelve Templars hanged because of the incident--with or without trial, William does not say. Nor does William supply the Pope's response to this flagrant violation of Papal authority. Apparently, Amalric felt justified in his action because he saw the Templars as vassals who had violated his trust in them, rather than as a group of clerics who were independent of his authority. 61

The hostility between the King and the Order came to a head in the second incident.

In 1173, the Old Man of the Mountain, leader of the Assassins, sent a peace envoy to Amalric, proposing an alliance. The Assassins were a radical group of Shi'ite Muslims who practiced terrorism against their enemies. If a leader, usually Muslim, opposed them, they murdered him.62

On his way back from the conference with the King, the Assassin envoy was attacked and killed by a band of Templars who were led by a one-eyed knight named Walter de Mesnil. Furious, Amalric demanded De Mesnil's arrest, but Eudes de Saint-Amand, refused, saying that he would send De Mesnil to the Pope for judgment, instead. Amalric had De Mesnil arrested, anyway, but died before he could take the matter further. The regent to his successor, Raymond III of Tripoli, declined to continue negotiations with the Assassins. Raymond's father had been the victim of the Assassin attack in 61 William of Tyre, A History of Deeds Done Beyond the Sea, vol. 2, 312. 62 Islam is divided into two sects, Shi'ism and Sunnism. The Shi'tes traced their Caliphs (religious leaders) back to the Prophet Muhammad's son-in-law, Ali, the fourth Caliph. Ali, and later his son Hussein, were murdered by rival claimants to the Caliphate who were not descended from the Prophet. Sunnis followed these rival Caliphs. Influenced by the brutal deaths of Ali and Hussein, the Shilites have ritualized the concept of martyrdom more than the Sunnis have. 
1152 which initially provoked the Temple's anger. In response to Raymond II's murder, the Templars had successfully invaded Assassin territory in northern Syria. For the next century, the Assassins paid tribute to the Templars. 63

The Templars' motives in this incident are obscured because the main source of this story is William of Tyre--the archbishop who was also the King's chronicler.64 William, of course, was more interested in presenting the King's side than that of the Templars. He was convinced that the Assassins (who were part of the Shi'ite Isma'ilite sect, and therefore, the sworn enemies of Nur-ad-Din, who was a Sunni Muslim) were interested in converting to Christianity. 65 The idea that the Assassins, who hated the Christians as much as they did the Sunnis, would make a treaty with the Franks seems dubious, to say the least. The Assassins were as devoted to Islam as the most passionate Crusader was to Christianity. 66 When the Assassins finally did choose sides, they made a treaty with Saladin, Nur-ad-Din's successor, and held to it throughout his lifetime. 67

One reason for the Templars' hostility to the treaty with the Assassins stems from the fact that it would have severely weakened their position in northern Syria. At this time, the Templars owned lands on three sides of the Assassin territory. The Assassins were also paying a tribute of 2,000 Bezants to the Order. As a group which would exist indefinitely, and in which any individual (even the Grand Master) was dispensable, the Templars (and the 63 Farhad Daftary, The Isma'lis: Their History and Doctrines (Cambridge: Cambridge University Press, 1990), 380 .

64 For a detailed account of William of Tyre's--and Amalric's--motives for attacking the Templars, and historians' interpretations of William's biases, see Malcolm Barber, The New Knighthood, pgs. 96-111.

65 William of Tyre, A History of Deeds Done Beyond the Sea, vol. 2, 392-4.

66 Historians of the Assassins seem especially unimpressed by William's assertion. See Farhad Daftary, The Isma'ilis, 398.

67 Amin Maalouf, The Crusades Through Arab Eyes, 182-3. See also Farhad Daftary, The Ismañlis, 398-9. 
other military orders) were uniquely immune to the Assassins' tactics of political assassination.68 The mutual hatred between Assassin and Templar indicates that the Assassins learned this imperviousness of the Order to terrorism through experiment.

Lacking more military methods of persuasion, the Assassins hoped that Amalric might force the Templars to lift their tribute, and Amalric was amenable to the suggestion. If the Assassins reneged on the proposed treaty, it would be the Templars who would suffer, not Amalric. The Templars almost certainly knew this, and Amalric's secrecy about the treaty (as well as the previous bad blood between the King and the Templars) would only have increased their suspicions.

How did this incident reflect Templar-Muslim relations? It is difficult to say. For one thing, the Assassins had no more allegiance to, or love for, the Sunni rulers of the region than the Crusaders did for the Byzantines. Templar hostility would not necessarily reflect any overall hostility toward Muslims if the Templars shared the prejudice toward Shi'ites that the Sunnis expressed. Since the crusaders derived most of their information on the Assassins from Sunni and Byzantine sources, this would not be far-fetched.

Another odd feature of this incident is the source of distrust between Amalric and the Templars. In his reprisal against the Templars over losing a castle in the 1160's, Amalric's main complaint appears to have been that the Templars had negotiated some sort of truce, or treaty, with Shirkuh, Nur-adDin's chief general, without the King's knowledge or permission. Since Amalric was willing to make similar concessions to the Assassins in 1173 (at 68 Lord John de Joinville, "The Crusade of Saint Louis," in Chronicles of the Crusades (London: Henry G. Bohn, 1848), 470-3. See also, Bernard Lewis, The Assassins: A Radical Sect in Islam (London: Weidenfield and Nicolson, 1967), 130-1, and Farhad Daftary, The Isma'ilis: Their History and Doctrines, 398. Neither Lewis nor Daftary give any credence to the idea that the Assassins ever had an interest in converting to Christianity. 
the Templars' expense), clearly his idea of treason was not conducting negotiations with the Muslims, but flouting his authority by conducting them behind his back.

The interests of all parties here were decidedly mixed. While Amalric, at the end of his reign, was willing to negotiate with Muslims when it suited him, he had also spent the previous years aggressively expanding his realm through conquest at their expense. The Templars, on the other hand, appear to have begun the 1160's with a cautiously good relationship with their Muslim neighbors. They seem to have eschewed battles for treaties when it was. feasible. By 1173, however, this attitude had hardened, with the Templars arguing against a possibly (albeit improbably) advantageous treaty with the Assassins. In 1179, Eudes de Saint-Amand would die in one of Saladin's prisons after being captured in battle.69

\section{Relations with Muslims}

Ironically, Arab chroniclers had more to say about the Templars than the Order's Frankish contemporaries. Some of these natural enemies of the Order even expressed respect for the Order, and recorded friendly relations with them. 70

This goodwill began to dissipate around the time of the Second Crusade, following the rise of Mahmud Nur-ad-Din, ruler of Syria. The major changes on the Muslim side during this time occurred during the reigns of Nur-ad-Din

69 William of Tyre, A History of Deeds Done Beyond the Sea, vol. 2, 443.

70 Usamah Ibn Munqidh, An Arab-Syrian Gentleman and Warrior in The Period of the Crusades, $163-4$. This famous passage is quoted frequently by Templar historians. It will be explored further in Chapter Four. 
and Saladin. Both were hostile toward a Christian presence in Palestine, but Saladin is credited with being more fanatical about it.

Nur-ad-Din succeeded his father, Zengi, Atabeg of Mosul, in 1149. Zengi had been an old opponent of the Templars. Nur-ad-Din continued this rivalry, which hardened into a personal hatred between the Order and Nur-ad-Din's successor, Saladin.

Following Nur-ad-Din's death in 1174, Saladin undertook to conquer, and unite, Egypt and the rest of Muslim Palestine. Having accomplished this, by 1180 he was ready to attack Latin Palestine. He began with the County of Tripoli, which he took that year.

Saladin's timing was excellent. The Latin Kingdom of Jerusalem was in disarray, due to the illness of its ruler, Baldwin IV. Baldwin, who had succeeded Jerusalem's last strong king, Amalric, in 1174, was a leper and a minor. He would die in 1185 at the age of twenty-four. An infant (Baldwin V) would succeed him for a few months. After the child's death, Baldwin IV's brother-in-law, Guy de Lusignan, became King of Jerusalem. Saladin's timing undoubtedly stemmed more from the intelligence of his spies and good strategy than luck.

On July 4, 1187, Saladin successfully lured a large force of Franks into a disastrous battle at a place called the Horns of Hattin, southwest of Tiberias. The Franks were badly beaten. The Templars, alone, lost several hundred men. Only their Grand Master, Gerard de Ridefort, and two other Templars escaped death--Gerard, as a valuable prisoner. He would later be traded by Saladin for the Templar castle at Gaza. The rest of the Templar forces were either killed in battle, or captured and executed. Since they were the disciplined core of the Crusader armies, they were too dangerous to let live if 
they would not turn apostate.71

Saladin nearly destroyed both the Templars and the Hospitallers at Hattin. In this battle, Gerard de Ridefort encouraged Guy de Lusignan to attack a much larger Muslim force. De Ridefort apparently feared that his enemy, Raymond of Tripoli, had betrayed the Christians to Saladin--with whom Raymond had a treaty. It is possible that Raymond betrayed the Franks to Saladin.72 De Ridefort was also obsessed with knightly honor, and may have been unstable. Following the battle, Saladin had the surviving Templars and Hospitallers beheaded. 73

Saladin took back almost all of Christian Palestine, but he reached too far. He also tried to destroy the military orders, but they would survive both him and his empire as well. Worse yet for the Muslims, the Templars would soon come back stronger than ever behind their new patron, Richard I King of England, in the Third Crusade.

\section{The Third Crusade}

The Third Crusade (1189-1192) grew up out of Europe's consternation at losing Jerusalem to Saladin in 1187 . This may explain why its leaders were so illustrious.

The King of England, Richard I (Coeur de Lion), the King of France, Philip II

71 Francesco Gabrieli, Arab Historians of the Crusades, trans. E.J. Costello, (Berkeley: University of California Press, 1969), 138-9.

72 R.C. Smail, "The Predicaments of Guy of Lusignan, 1183-87," in Outremer: Studies in the History of the Crusading Kingdom of Jerusalem, eds. B.Z. Kedar, H.E. Mayer, and R.C. Smail, (Jerusalem: Yad Izhak Ben-Zvi Institute, 1982), 173-5.

73 For Imad-ad-Din's description of the massacre, see Francesco Gabrieli, Arab Historians of the Crusades, 138-9. Imad-ad-Din describes Saladin's expression at the massacre as "joyful." 
(Augustus), and the Holy Roman Emperor, Frederick I (Barbarossa) each mounted separate expeditions to march on the Holy Land. Frederick took the overland route and drowned in Asia Minor. Richard and Philip, however, made it to Palestine. Richard won back much of the territory lost to Saladin, with the notable exception of Jerusalem. His advisors, both among the local barons and in the military orders, advised him against attempting to retake it. Richard's candidate, Robert de Sablé, was now Master of the Order. Under him, the Templars had regained their characteristic levelheadedness, and they knew that Jerusalem was indefensible for the permanent Palestinian forces. It was landlocked and isolated from the rest of the Crusader lands. It lacked a large population and vigorous trade. The port city of Acre, which Richard and Philip retook, was far more important.74 Richard officially ended the Crusade by making a treaty with Saladin, who was tired, and prematurely old at 54, in 1192. The conflict actually ended with Saladin's death in 1193, and the failure of his successors to follow up on his victories.

Both Richard and Philip were favorably inclined toward the military orders. Richard, like his father Henry II and his mother Eleanor Duchess of Aquitaine, especially favored the Templars. 75 He relied on their advice and support throughout the Crusade. Afterwards, they tried to smuggle him back to England disguised in their ranks but were ultimately defeated by his arrogance and his enemies' alertness. Still, he continued to show them favor, as did his brother, John, after him.

Saladin's campaigns broke the back of the Palestinian, Frankish nobility, and the King of Jerusalem was left without a kingdom. The military orders: The Templars, the Hospitallers, the small order, the Knights of St. Lazarus 74 Malcolm Barber, The New Knighthood, 117-20.

75 For Eleanor's donation to the Temple in La Rochelle, see Marquis D'Albon, Cartulaire Général de L'Ordre du Temple, 1119?-1150 (Paris: Librairie Ancienne, 1913), no. 194, 135-6. 
(whose mission was the care of lepers), and the Teutonic Knights (formed in Acre in 1198 on the model of the Templars), benefited the most from the Third Crusade.76 Saladin had tried to destroy them, but had exceeded his grasp. None of Saladin's seventeen sons took up his cause after his death. Nor did his brother. Instead, his heirs fought over their inheritance. The disparate elements of the caliphate that his personality and army had kept together quickly disintegrated. After his death, his brother, al-Adil, seized Egypt while his sons quarreled over Syria.

Saladin had bankrupted Muslim Palestine both in finances and fanaticism. The cohesiveness of his armies had depended as much on their mutual greed for plunder as their religious zeal. 77 Saladin exhausted both impulses in his drive to expel the Franks from Palestine. His immediate successors and their subjects would not share his fascination with jihad, and would find peace much more profitable than war. 78

The Franks, for their part, needed time to reconsolidate the lands won back in the Third Crusade. They were as eager to trade and make treaties with the Muslims as the Muslims were to treat with them. This would not last. For the next 40 years, however, the military orders and the Muslims, freed of the fanaticism and rivalry between the likes of Gerard de Ridefort and Saladin, went back to business as usual.

76 Udo Arnold, "Eight Hundred Years of the Teutonic Order," in The Military Orders: Fighting for the Faith and Caring for the Sick, Maicolm Barber, ed. (Cambridge: Variorum, 1994), 223-4. 77 R.C. Smail, Grusading Warfare, 74.

78 Robert Irwin, "Islam and the Crusades, 1096-1699," in The Oxford Illustrated History of the Crusades, 236-7. 


\section{CHAPTER TWO: THE TEMPLARS--THEIR FALL}

\section{The Great Bankers}

The 13th century began well for the Templars in Palestine. Saladin's empire fell apart within hours of his death and the Muslims now fought among themselves far more than they fought the Christians. The Palestinian barons had been reduced to irrelevance as a political force at Hattin and the King of Jerusalem no longer had a realm. The quarrelsome kings of the Third Crusade had either died or gone home. Business and trade were booming and the new Pope, Innocent III, cherished the Temple. Some local Frankish families, such as the Ibelins, remained, but they tended to side with the military Orders. The only real rivals remaining were the Italian merchants and the Hospitallers.

The rise of the military orders coincided with the decline of the free Palestinian barons. The Hospitallers had existed as a charitable organization since 1040 in Jerusalem, and had been instrumental in providing information necessary for the capture of that city. 1 Following the end of the First Crusade, therefore, they had received many gifts from Europe, and the Crusaders, and had waxed rich for 20 years previous to the origin of the Templars. That they suffered a somewhat less virulent reputation than the Templars stemmed more from their non-military occupations than from any higher sense of morality. The Templars' reputed sins were mainly pride and simony. A most 
accurate definition of "simony," as applied to the Templars, would be miserliness, rather than theft. As seen in Chapter One, the Templars despised theft, and their reputation for honesty was nearly as proverbial as their reputation for high-handedness and lack of charity. Some writers also portrayed them as less educated, and plainer-spoken, than the Hospitallers. ${ }^{2}$

The Hospitallers, on the other hand, were frequently accused of guile, heresy--and embezzlement. ${ }^{3}$ The Teutonic Knights were also subject to these temptations. One highly placed embezzler, the Grand Master of the Teutonic Knights, was sentenced to join the Temple as penance. 4 The Hospital continued to advertise its popular hospices and hospitals for pilgrims, and restricted itself to more conservative business ventures, such as traditional manorial farming. 5 The Templars, on the other hand, cultivated cash crops on their estates and actively cultivated the questionable profession of banking from the Second Crusade onward.

Medieval banking existed in a moral gray area from the 10th century until well into the 15th century. Before this period, Europe was too poor to support an extensive, morally corrupting banking system. By the end of the 15th century, the major Italian banking houses had learned ways of circumventing Church disapproval in their financial transactions. When they could not find loopholes, they increasingly violated the religious prohibitions. The realities of a rapidly growing, international economy aided such rich merchants in showing the Church the practicality of turning its head. Also, a century and a half of schism, exile, and unseemly grasping for worldly power had weakened the Church's moral power over her subjects.

2 Helen Nicholson, Templars, Hospitallers, and Teutonic Knights, 43, 68, 73.

3 lbid. $_{2}$ 73, 133.

4 Malcolm Barber, The New Knighthood, 220.

5 Malcolm Barber, The Trial of the Templars, 247. 
The Church's main objection to banking was the practice of usury. This is the practice of lending at rates of interest which are considered excessive, or even punitive. Some medieval moneylenders, for example, lent out money at rates as high as $100 \% .6$ Most moneylenders, however, did not charge a rate above $331 / 2 \%$, which was usually accepted as the ceiling for non-usurious interest.7

Many Church preachers, beginning in the latter 12th century, had an even stricter definition of usury. These preachers defined usury as any transaction in which the lender received back more then he lent out. Their reasons were two-fold. First, interest was seen as money received without effort on the part of the lender. Since money--by itself--was infertile, the lender had done nothing to earn such money. Therefore, usury was a form of theft. Second, interest was seen as money which worked day and night, Sundays and Holidays, without rest. Thus, usury violated the Lord's commandment to rest on the Sabbath, and was therefore a thief of time. 8 Money earned through such theft was believed to be destructive by nature. 9

Usury was an especially difficult sin for which to make penance. In order to avoid some very graphic, eternal torments (which the preachers described with relish), the usurer had to make restitution directly to his victims by reimbursing them with those of his riches extorted from them through usury. Simple charity would not do. If his victims were dead, or otherwise beyond his power to repay, the usurer might be condemned to Hell, despite his best

6 Robert S. Lopez, "The Dawn of Medieval Banking," in The Dawn of Modem Banking, ed. Center for Medieval and Renaissance Studies (New Haven: Yale University Press, 1979), 4. 7 Jacques Le Goff, Your Monev or Your Life, trans. Patricia Ranum (New York: Zone Books, 1988), 71-2.

8 lbid., 27-31.

9 Jacques Le Goff, "The Usurer and Purgatory," in The Dawn of Modem Banking, 37-8. 
intentions. 10

The preachers' definition of usury encompassed many of the more complex forms of banking, but there were exceptions. The commenda, for example, was not considered usurious. This was a contract between two merchants in which one merchant supplied the capital for a business trip, whereas the other merchant made the actual trip, and conducted all the business thereof. The interest charged was the cut of the profits which the former merchant exacted from the latter in exchange for risking his capital to finance the venture. The ship loan, a form of the commenda, was also allowed because the Church recognized that the increasingly popular commerce made by ship was much more hazardous than land travel. 11 This was a loan in which the interest was seen as a compensation for the risk which the lender took in supplying his money for a hazardous venture. Compensation for financial risk, therefore, was seen increasingly as a legitimate exception to the prohibition. The usurer could also keep sufficient funds (even if they originated from usury) to prevent himself and his family from starving. 12

Originally, the banking profession was dominated by non-Christians--Jews in northern Europe, Jews and Muslims in the southern, frontier regions. ${ }^{13} \mathrm{~A}$ new Christian merchant class, often referred to collectively as Lombards, pushed most non-Christians out of the banking business by the end of the 15 th century. 14 One of the first groups to successfully challenge the Jewish

$10 \mathrm{lbid} ., 80-4$.

11 Raymond de Roover, Money, Banking and Credit in Mediaeval Bruges: Italian MerchantBankers Lombards, and Money-Changers, a Study in the Origins of Banking (Cambridge: The Mediaeval Academy of America, 1948), 50-1.

12 Jacques Le Goff, Your Money or Your Life, 81-2.

13 Aziz S. Atiya, Crusade, Commerce and Culture (Bloomington: Indiana University Press, 1962), 195-6.

14 Richard W. Emery, The Jews of Perpignan in the Thirteenth Century: An Economic Study Based on Notarial Records (New York: Columbia University Press, 1959), 106-8. 
monopoly was the Templars.

All three religions--Christian, Jewish, and Muslim--had similar prohibitions against usury. These prohibitions derived from passages in the Old Testament. All three religions, in theory, waived these prohibitions when the moneylender engaged in transactions with those outside of his faith.

Christians, however, did not always consider Jews as technically foreigners in financial matters. 15

The Templars side-stepped the taboos against usury in two ways. First, whenever they lent money, the transaction always showed the amount which was to be paid back, not the amount originally lent. This masked the interest charged to the borrower. ${ }^{16}$ Second, the Templars often took over the management of entire estates. They might take ownership of the property permanently, or they might merely manage it, keeping all, or part, of the profits from the property, until the owner took back the original estate. 17 The real owner could demand, and receive, a report on the current state of his or her property on a daily basis (except on Sundays and feast days). ${ }^{18}$

The Templars kept very careful records of the property under their care. Their organization was ideal for individuals who transferred funds using a bill of exchange.19 They tended to provide medium sized loans to relatively ordinary people, being rarely considered as backers for the huge loans with

15 Jacques Le Goff, Your Money or Your Life, 21-2.

16 Malcolm Barber, The New Knighthood, 277.

17 Glenn Olson, "Italian Merchants and the Performance of Papal Banking Functions in the Early Thirteenth Century," in Economy, Society, and Government in Medieval Italy: Essays in Memory of Robert L. Reynolds, eds. David Herlihy, Robert S. Lopez, and Vsevolod Slessarov (Kent:

The Kent State University Press, 1969), 44.

18 Malcolm Barber, The New Knighthood, 269-70.

19 A bill of exchange was a letter stating that the bearer had deposited money with the organization at his point of departure, and was entitled to draw upon the organization's funds at his point of arrival. This bill was used regularly by merchants from the 12th century onward; Raymond de Roover, Money, Banking and Credit in Mediaeval Bruges, 52. 
which the great Italian merchants supplied the Papal and various royal treasuries. It was not uncommon, however, for kings and great nobles to extract emergency funds from the Temple while on crusade, or to entrust it with the management of their financial affairs back home. Until 1307, the Templars even ran the royal treasury for the King of France.20 When Philip IV replaced them in this post with his own councillors, this appears to have been more for the purpose of isolating them prior to arrest than for any suspicion of dishonesty. The charges which were later made against the Temple dwelt obsessively on heresy, ritual pollution, and idol worship. Mismanagement of funds, per se, was never mentioned as a reason for eliminating the Order.

The Templars were favored by both great and small investors because of their reputation for honesty, security, and intelligent investment. These investors included nobles and non-nobles, rich and those of modest income, men and women. The financial empire of the Temple, like its shipping industry, seems to have been completely separate from its military activities, but this is an illusion. It was the Templars' reputation as skilled, and vindictive, fighters that protected their international investments and shipping industry. This protection was not foolproof--Templar estates were occasionally raided throughout their history. It was, however, sure enough that investors great and small put their faith in it time and time again as they had put their faith in the protection of saints' relics in previous centuries. While crusading enthusiasm did wane in the late 13th century, there is no evidence that the Temple was in immediate danger of penury. In fact, as its military activities decreased in success, its banking and shipping (including privateering) activities flourished.

The faith of investors in the Temple appears to have been appropriate.

20 Joseph R. Strayer, "Italian Bankers and Philip the Fair," in Economy, Society, and Government in Medieval Italy, 117. 
John de Joinville recounts that when King Louis IX of France fell short in the payment of his ransom to the Muslims (following his capture at Damietta), De Joinville was forced to extort, through threats of violence, a loan from the Temple. The Temple had on board its ships money which many of the poorer Crusaders had entrusted to it for safekeeping. The Templar leaders protested, in vain, that the King was stealing from his own followers. They knew from experience that a crusading King was unlikely to pay them back, and that they would be forced to make up the lack.21

\section{Conflict Between and Within the Orders}

Despite the Hospitallers' headstart, the Templars soon eclipsed them. This was probably the origin for the later antipathy between the two orders.

Usually, their rivalry was only political, but sometimes it could lead to civil war.

In Palestinian politics, the two orders were often found on opposite sides.

One of the most significant periods of conflict occurred during the reign of Baldwin IV of Jerusalem, the leper King. Upon Baldwin's death in 1185, the Templars favored the succession of Baldwin's sister, Sybil, and Guy de Lusignan, her husband.22 The Hospitallers supported the other side, which desired the election of a new ruler from among the Palestinian barons. During the 13th century, this rivalry, which drew criticism from European observers,

21 Lord John de Joinville, "The Crusade of Saint Louis," in Chronicles of the Crusades , 455-6. 22 R.C. Smail, "The Predicaments of Guy of Lusignan, 1183-87," in Outremer, 164. The Kingdom of Jerusalem was unique in major medieval royal houses in that it allowed multiple routes of succession. Several early kings acquired the throne through election, not by inheritance. Inheritance of the title during the 13th century, on the other hand, passed almost exclusively through the maternal, or sororal, line. Since the throne passed through the Queen and not the man she married, she could, in theory, marry and divorce at will, until she found a man who pleased her. Then, she could force her choice on the Palestinian nobility as King. 
occasionally degenerated into street warfare in the cities--and even attacks on each others' castles. 23

Increasingly, the two Orders each made their own treaties with the Muslims, which often contradicted the interests of the remaining local nobility and of the other religious orders. This rivalry was occasionally alleviated by comradeship and loyalty between individuals--even to the detriment of each Order's internal policies. 24 Occasionally, they even went into battle against the Muslims together.25

The two Orders were united in one other thing. In the 13th century, they were the largest land owners in Palestine. The Templars, alone, held nearly a third of the Frankish land in the region. As the Palestinian barons had either gone bankrupt, or died out, the military orders had been forced to buy their land, to keep it out of the hands of the Muslims. Some critics accused them of deliberately impoverishing local Franks in order to acquire more territory. This seems unlikely. The orders complained often about the strain this extra burden put on their finances and manpower.

While land was power in the Middle Ages, any intelligent landowner knew that indefensible holdings on a frontier were less than useless. Such properties attracted dangerous scavengers. This was why the military orders refused all Muslim offers during the 13th century to return Jerusalem to the Franks. The city was isolated from the other Frankish territories, and it had

23 Desmond Seward, The Monks of War, 77-8. Not all historians agree that this rivalry was either constant or serious. See A.J. Forey, The Military Orders, 214.

24 La Règle du Temple Henri de Curzon, ed. (Paris: Librairie Honoré Champion, 1977; reprint, Paris: La Société de l'Histoire de France, 1886), nos. 576-7, 299-300. The web of treaties which protected the military orders was incredibly intricate, and even more ancient and critical to their defense than their systems of fortifications. It could also lead to strange alliances; Jacques de Molay once allied himself with the Mongols, who nearly took over Palestine, Muslim and Christian, in the 1250's; The Rule of the Templars, trans. J.M. Upton-Ward, 149 n.576.1. 25 Malcolm Barber, The New Knighthood, 137-8. 
never had a strong economy of its own, even allowing for the pilgrim trade. Without the surrounding territory (which was never offered), the city was impossible to keep.26

Many new crusaders--through their propagandists--successfully criticized the military orders for their supposed apathy about regaining Jerusalem. These writers did not understand the political and military realities facing the Palestinian Franks--nor did they often care. The Templars were always seriously understaffed, undersupplied, and underfunded in the Holy Land. They repeatedly complained about the strain created on their resources to maintain the holdings they did have, let alone develop new acquisitions.

The Templar Order was not the monolithic entity which the dearth of internal documents--due to time, neglect, and the violence of its suppression-may imply. At least two extremes vied for control within the Order. One element was heavily arabized. It preferred negotiation and, possibly, local military tactics to work within the dominant Muslim culture. Guillaume de Beaujeu, with his network of spies and his intimate knowledge of local Muslim politics and players, embodies this element perfectly. Many of the sergeants, especially the poulains (brothers of Syrian descent), and the early Templars portrayed in Usamah's anecdote also fall into this category.

The other element followed the codes and military tactics of Frankish chivalry, and opposed any compromise with the Muslims. Jacques de Molay, Gerard de Ridefort, and probably most new recruits from Europe fit into the latter category. De Ridefort, himself, had been a member of the Order for less than five years before his election to Grand Master, although he may have spent over a decade in Palestine previous to the disaster at Hattin. $27 \mathrm{He}$ 26 Joshua Prawer, The Crusaders' Kingdom: European Colonialism in the Middle Ages (New York: Praeger Publishers, 1972), 39-40, 82.

27 Malcolm Barber, The New Knighthood, 109-110. 
refused to adapt to local conditions of warfare--with disastrous results.

De Molay referred to this split in the Order while defending De Beaujeu's reputation against Guillaume de Nogaret's accusations of treason at the Trial. Molay admitted that he and others had opposed De Beaujeu's cautious treaties and alliances in their youth, but insisted that De Beaujeu had been loyal to the Christian cause. Like Clement V with Boniface VIII, De Molay was forced to support his predecessor's despised policies in order to preserve the Order's reputation.28

The arabist element appears to have dominated Templar policies for most of the Order's career. Although the Frankish element occasionally imposed itself from the outside (i.e., St. Bernard's patronage, Gerard de Ridefort's Mastership, and Richard l's appointees during the Third Crusade) the Order always reverted to a conciliatory policy after such martial periods. This probably derived more from the relative weakness of the Franks in Palestine than from any interreligious tolerance inherent in the Templar character. After the Order left Palestine, its general policies corresponded more to contemporary European prejudices against Muslims than before.

\section{The Internal Crusades}

Despite Innocent III's patronage, his papacy produced no military relief for the Order in Palestine. Three crusades began during his tenure--the Fourth Crusade of 1204, the Children's Crusade, and the Albigensian Crusade.

The leaders of the Fourth Crusade were diverted by the. Doge of Venice to pillage Constantinople instead of the Holy Land and created a Latin 
Byzantium. The Doge resented Byzantium's trading power and saw the crusaders as a way to eliminate this rival. His leverage was a monopoly on transportation by ship. Without his aid, the crusaders could not reach the Levant. The Latin empire in Byzantium lasted almost three quarters of a century before reverting to Byzantine rule.

It is probably no coincidence that the Templars developed their own fleet shortly after the Fourth Crusade--breaking the Italian monopoly.29 This was fortunate, since it coincided with the decline of naval power in the Islamic worid. The great Muslim pirate fleets that terrorized the southern coasts of Europe and battled Byzantium during the 9th and 10th centuries later so declined that in 1274 the Pope estimated the Sultan of Egypt's fleet at less than 20 ships. 30 Muslim pirates did not prowl the Mediterranean again until the 18th and 19th centuries, when the Ottoman Empire, like the Byzantine Empire it had replaced, began to decay. By the end of the 19th century, however, the pirates' resurgent power had been permanently broken by the French and the British.31

The Muslims' immediate successors at sea were the military orders. The Templars dominated the Mediterranean sea off the Levant during the late 13th century. They continued to raid the Palestinian and Egyptian coasts after the fall of Acre, using Cyprus as their base of operations. The raids stopped only with the arrests for the Trial. Hospitaller fleets, however, continued to raid Muslim territory well into the 18th century.

The Children's Crusade in 1212 embodied the worst in medieval religious belief. Large groups of young people, ranging in age from 12 to 30 , set out for

29 Malcolm Barber, The New Knighthood, 237.

30 lbid. 171.

31 Philip K. Hitti, History of the Arabs: from the Earliest Times to the Present (New York: St. Martin's Press, 1968), 711-8. 
the Holy Land on Crusade. Like Peter the Hermit's mob during the First Crusade, they came mostly from the non-noble classes, incited pogroms and plundered towns on their way, and made themselves so obnoxious to local authorities through whose regions they passed that they were soon attacked and either killed or sold into slavery. None of them reached Palestine.

The Albigensian Crusade was the first great crusade within Christendom. The Kingdom of France, with the Pope's blessing, invaded Toulouse, in Southern France, in 1209. The excuse was that the majority of the southern French followed a heresy called Catharism. Cathars believed in a dualistic worldview wherein all flesh was bad and only the spirit was good. Due to the incompetence and corruption of the southern French clergy, the populace had turned to the Cathars, who believed that the Church was part of the evil, material world. The Church created the mendicant Dominican Order to counteract this image. The Dominicans, however, grew frustrated with their task and soon turned to force--exacerbating the situation.

The Cathar priests were vegetarian, ascetic, and celibate. They would later be accused of homosexuality (because they often traveled in pairs) and of engaging in ritual suicide and murder. These rumors have little basis in fact. 32 Early critics of the Cathars also claimed that the term Cathar derived from cattus, the Latin word for "cat," and accused the Cathars of worshiping a catlike idol. This theory has since been discredited. Cathar is now believed to derive from the Latin word for "pure." 33

That the Templars were later accused of homosexuality and worshiping an idol in the shape of a cat is probably no coincidence. The author of the

32 Walter L. Wakefield, Heresy, Crusade and Inquisition in Southern France, 1100-1250 (Berkeley: University of California Press, 1974), 39-41.

33 Norman Cohn, Europe's Inner Demons: An Enquiry Inspired by the Great Witch-Hunt (New York: Basic Books, 1975), 22. 
charges, Guillaume de Nogaret, came from Toulouse. Hostile rumor attributed Catharist ancestry to him.34 Although the charges reflected De Nogaret's own neuroses far more than any Templar flaws--known or secret--the Templars and the Cathars have since been linked in myth, down to the present time. Historically, the Templars had no great involvement in this Crusade, and appear only on the periphery of its historiography. If anything, they had little sympathy for the Cathars, who opposed forcible conversion of non-Christians. Like the Waldensians, the Cathars criticized the killing and forcible conversion of non-Christians during the Crusades, citing Christ's willingness to be arrested in Gethsemane instead of allowing St. Peter to defend him against his attackers. 35

Beginning in 1209, the Albigensian Crusade continued for 17 years. At the end, southern France was devastated and the idea of Crusade permanently tainted. France was drained of funds, manpower, and enthusiasm. In Palestine, the military orders and the Frankish nobility were abandoned to their own resources.

\section{The Heretic Emperor}

The Fifth Crusade (1218-21) began well for the Templars. For years, Innocent III had been threatening the Holy Roman Emperor, Frederick II, with excommunication because Frederick had put off fulfilling a crusading vow. Frederick had many enemies. He knew that Innocent III supported some of

34 Peter Partner, The Knights Templar and Their Myth [The Murdered Magicians] , 2nd ed., (Rochester: Destiny Books, 1990), 53.

35 Elizabeth Siberry, Criticism of Crusading, 1095-1274 (Oxford: Clarendon Press, 1985), $212-$ 6. 
them because Frederick's ambitions in Italy threatened Innocent's own imperial aspirations. So, Frederick delayed. Following Innocent's death, however, Frederick decided to risk a crusade. The King of Hungary and the Duke of Austria had preceded him in 1217 and the Palestinian Franks began the Crusade in anticipation of his arrival.

Long-term Templar military strategy had changed markedly from that of the previous century. Throughout the 12th century, the Order had advocated the taking of Damascus as the key to dominating the Holy Land. Now, after Saladin and his successors had established themselves in Egypt, Frankish interest focused on the Aiyubid Sultanate there. 36

The Crusade began well with the successful capture of Damietta, an important Muslim city on the Nile delta, in 1219. During the siege, the Templars distinguished themselves in amphibious warfare against the Muslims. The crew of one Templar ship, attacked during a sally against the city, scuttled the boat, taking five Muslim ships with them. 37 This siege demonstrated once again the Templars' ability to adapt creatively to unique battle conditions, and their absolute dedication to the ideal of the crusade.

The Crusaders had taken Damietta in anticipation of Frederick's arrival with reinforcements. Frederick, however, delayed his arrival in Palestine. Alone, the combined forces of European crusaders, Palestinian barons, and military orders were unable to hold the city permanently. The Christian army was forced to surrender it in 1221. The terms of surrender were not as humiliating as they could have been, due to the weakness of Al-Kamil, the Sultan of

36 Meron Benvenisti, The Crusaders in the Holy Land (New York: The Macmillan Company, 1970), 6-9.

37 Wentworth S. Morris, Amphibious Siegecraft in the Fifth Crusade: The Siege of Damietta, 1218-1219 (Athens: Th. \& Ath. Ioannidis Brothers, 1967(?)), 14. 
Egypt, but they were humiliating enough. 38 Damietta, and Egypt, would remain a crusading goal for the rest of the century. 39

Frederick finally stopped delaying in 1228 . The Templars and the Hospitallers were so ecstatic that they literally fell at his feet when they came to meet him at Acre. They believed that he understood local conditions because he could speak Arabic and was widely read. Unfortunately, Innocent's successor, Pope Gregory IX, had grown tired of Frederick's political maneuvers and excommunicated him. The Templars were forced to disavow him as their leader, because an excommunicated lord could claim no fealty from his vassals--even when on crusade. 40

The Templars also soon discovered that Frederick's education had made him neither tolerant of others' opinions, nor informed about the delicate interplay of local Palestinian politics. Frederick was an autocrat who was used to absolute obedience from his vassals. When the Templars vacillated in their fealty between him and the Pope, he reacted with force. He marched to the great Templar castle of 'Atlit, and demanded its surrender. Rebuffed, he arrived at a compromise with the military orders that temporarily resolved the situation politically, but weakened the crusading army.

Frederick finally decided to return to Italy in early 1229 because the Pope's armies were pressing his forces hard. He concluded a 10-year treaty with AlKamil which satisfied no one and which no one honored. The treaty gave the Franks Jerusalem, but under onerous terms which made it indefensible. The Franks were forbidden to fortify the city, or its environs, and the Templars were

38 Al-Kamil's reign was marked by considerable turmoil. He was repeatedly forced to buy off the Franks and the Muslims remained on the defensive until after his death.

39 Following their expulsion from Palestine in 1291, Templar ships continued to raid Egypt, and the Order's Grand Master, Jacques de Molay, supported an attack on Egypt as a beginning to reclaiming the Holy Land.

40 Edward Burman, The Templars, 125-6. 
forbidden to reoccupy their traditional quarters on the Temple Mount.

The Templars and Hospitallers protested. Frederick responded with an unsuccessful assault on the Temple house in Acre. Unable to hurt them physically, he, and later, his sons, circulated negative propaganda against them through sympathetic chroniclers such as Matthew Paris and Bartholomew of Neocastro. The Templars responded with propaganda of their own, through the Ibelin chronicler Philip of Novara and the Templar of Tyre.41

Once he returned to Italy, Frederick seized some of the Temple's holdings, and sent his own forces to Palestine--ostensibly to help defend it. Frederick's bailli took over Tyre, remaining in conflict with the local Franks and the military Orders until 1243, when he was driven out. Supporting the Queen-Dowager of Cyprus's claim to the throne of Jerusalem against Frederick's son in the early 1240 's did not help the Templars' cause with the Emperor. Their relations with him remained strained until his death. The military orders were forced to wait until Frederick's son, Conrad, died to regain many of these possessions.

\section{La Forbie}

During the 1230's, two new threats arose from the East. The first, the Khorezmian Empire, disintegrated quickly. Although it damaged the eastern part of Muslim civilization, and weakened the Byzantine Empire, it fell apart due to internal dissensions, attacks by the Aiyubid Sultanate in Egypt, and pressure from a greater threat, the Mongols. The Mongols would soon permanently change the face of eastern Europe and Near Asia, but this was

41 Helen Nicholson, Templars, Hospitallers, and Teutonic Knights, 11, 46-8; Malcolm Barber, The New Knighthood, 131-6. 
not yet clear to either Muslims or Christians.

For five years after Al-Kamil's death in 1239, the Franks benefited from the fragmentation and shifting policies of the surrounding Muslim enclaves. Unfortunately, some observers in Europe were very critical of the local Franks because of disputes between the Templars and the Hospitallers. The two orders agreed on general policy (a careful network of alliances with, and raids on, their Muslim neighbors), but disagreed on whom to cultivate, and whom to intimidate. The Templars wanted to treat with Damascus, although they did not mind playing the Damascenes against the Egyptians. The Hospitallers preferred to cultivate Egyptian goodwill. 42

Initially, Templar policy retained the upper hand. In 1244, however, the Sultan of Egypt allied with the Khorezmians, who were still powerful. The political situation immediately began to destabilize. A force consisting of Templars, Hospitallers, Teutonic Knights, and local Frankish nobility was forced into a battle with the Egyptians and Khorezmians at La Forbie (now Harbiyah, not far from Gaza) on October 17, 1244. The Franks were massacred. The Templar Grand Master, who probably opposed the battle, was one of the casualties.

The Sultan of Egypt went on to retake Damascus, and several Frankish towns. His luck did not last. He died in 1249, during the Sixth Crusade. His dynasty ceased to exist in 1259 when a Mamluk (a soldier of the Egyptian palace guard) established himself as Sultan. The Templars, meanwhile, had found another royal patron.

42 Peter Jackson, "The Crusades of 1239-41 and Their Aftermath," in Bulletin of the School of Oriental and African Studies 50 (1987), 58-9. 


\section{Saint Louis of France}

King Louis IX of France (later Saint Louis), after experiencing a near-fatal illness in 1244, resolved to thank God by going on crusade. He possessed qualities similar to Saladin. Like Saladin, he took his religion very seriously. He attended Mass regularly, regulated his personal habits (eating, drinking, and sleeping) with spartan vigor, was faithful to his wife, and regularly distributed alms to the poor. He was also harsh toward enemies of Church and State--real or perceived--and forced his family to follow the same ascetical rigor as he did. Unlike Saladin, Louis did not devastate his own lands with his holy war. Nor did he waste his entire reign upon it. Nevertheless, Louis' four years of Crusade nearly bankrupted France. 43 It would be the last time for several hundred years that Europe could field such a large force in the Holy Land.

Louis' ascetic example to his children was so pervasive that it negatively affected the personality of his grandson--Philip IV. Philip possessed many of Louis' less admirable traits (intolerance, rigidity, and ruthlessness toward his enemies) while lacking the charisma and strong sense of honor that united the divisive Franks in Palestine under his grandfather's banner.

When Louis arrived in Palestine in the summer of 1248, the Templars immediately came under Louis' influence, and he under theirs. Still, they did continue their private negotiations with the Muslims. This caused trouble at least twice with the King, who did not believe in negotiating with the Infidel. The second time occurred in 1252. While many members of the Crusading army were in Egyptian hands, the Templars arranged a treaty with Damascus, which was involved in the civil war in Egypt between the Sultan's

43 Norman F. Cantor; The Civilization of the Middle Ages 4th ed., New York: HarperPerennial, 1994 (New York: Macmillan, 1963), 463-4. 
descendants and Mamluk rebels. When he found out about the treaty, the King forced the Master of the Temple to openly renounce it and undergo public humiliation before the Crusader army. 44

Louis' insistence on retaining absolute authority over the Crusading army did not cause the same intransigence in the Temple that Frederick's highhandedness had in 1228. Although they continued their secret policies, the Templars publicly supported Louis throughout the Crusade. They never publicly defied the King, nor murmured against him as they had against Frederick.

Why did the Templars submit to Louis, and not to Frederick? For one thing, Louis' Crusade had been sanctioned by the Pope. So orthodox was the French King that he would later be canonized as a saint. Another, perhaps even more compelling, reason was that Louis ruled France, the country which held the heart of Templar power and influence in Europe. A third reason was that Louis, like Richard Coeur de Lion, relied upon the Templars throughout the Crusade and rewarded them accordingly. Like his anger, his largess was great. When the Assassins sent an envoy to Acre to threaten Louis in 1251, the King received the messenger with the Grand Masters of the Temple and the Hospital by his side. The two Grand Masters so terrified the envoy that the Assassins were ultimately forced to remain neutral throughout the conflict in Egypt.45 Later that year, the Queen of France gave birth to a son at 'Atlit, the great Templar castie on the Samarian coast, south of Haifa. Reginald, the Grand Master of the Temple (who was selected for his position by Louis), was godfather to the child.

44 Malcolm Barber, The New Knighthood, 154.

45 Lord John de Joinville, "The Crusade of Saint Louis," in Chronicles of the Crusades , 470-1; Matthew Paris, Matthew Paris's English History: From the Year 1235 to 1273 vol. II (London: Henry G. Bohn, 1853; reprint, New York: AMS Press, 1968), 366-73 (page references are to reprint edition). 
In 1249, the summer following his arrival, Louis agreed to attack Egypt. The Franks immediately took Damietta with the loss of only one life. Despite this fulfillment of their dreams, the Templars would suffer considerable loss of life and resources during this campaign. In the winter of $1249-50$, following the death of the Egyptian Sultan Aiyub, the Crusaders decided to attack Cairo. The Templars led the army. In February, 1250, while fording a tributary of the Nile which had delayed them for a month, they encountered disaster in the town of Mansurah.

In this battle, a French noble, the Count of Artois, and a party of Franks attacked the Muslims while the Templars were still fording the stream that separated them from the town. The Templars, humiliated, followed the Count into Mansurah and became trapped in the streets. Nearly 600 men were killed, 280 of them Templars. 46 Some of the other dead were Hospitallers. A few days later, the Egyptians attacked the Crusader camp. The Grand Master of the Temple, Guillaume de Sonnac, had survived Mansurah, and a subsequent raid. He did not survive this battle. 47 His successor was the aforementioned Reginald de Vichiers, godfather to the King's son.

There are two sources for the battle of Mansurah, John de Joinville and Matthew Paris. De Joinville is a sympathetic source; Paris, a hostile one-usually. Although neither De Joinville nor Paris blamed the Templars for the ill-considered attack, Paris used the event as an excuse to accuse the Templars of avarice and cowardice. These charges would linger until the Trial.

The fighting in February stopped the campaign. In April, the Crusaders were forced to retreat. The Egyptians attacked again and the King was captured in the fighting, along with most of his army. The losses among the 
military orders rendered their power temporarily non-existent.

The initial ransom for the army was set at 500,000 livres, but it was eventually lowered to 400,000 livres. The ransom for the King, himself, was Damietta. The Mamluks had chosen this moment to assassinate the Sultan of Egypt and initiate a bloody civil war that would continue until 1259.48 Louis was able to escape this volatile political situation by delivering 200,000 livres and Damietta immediately, and by leaving his brother, Alphonse de Poitiers, as a hostage. When the ransom came up short by 30,000 livres, the King, through John de Joinville, was forced to borrow it from the Templars, who had ships offshore. Due to confusion following the death of their Grand Master, some of the Templars refused to hand over the money, because it was not theirs. They were guarding it for individuals in the Crusader army. De Joinville was forced to stage the mock robbery mentioned previously to accomplish the loan.

Louis returned to Europe in 1254. A year later, the Mongols suddenly rose as a threat to Palestine. In 1258, they destroyed Baghdad. In 1260, they swept through Palestine. The Franks, for the most part, stayed out of their way. Lacking any way of stopping them (the Franks held only three castles able to withstand the Mongol army--two of them belonging to the Templars), the Franks signed a non-aggression pact with the Mongols, but refused to help them.

In September of 1260 , the Mamluks met the Mongols at the town of 'Ain Jalut, in southern Galilee. The Mongols were defeated and their general,

48 The Mamluks were slaves of Turkish origin who had been raised since childhood to be soldiers. They had comprised the personal guard for the Egyptian caliphs and sultans for over a century. Like the Praetorian Guard for the Emperor of ancient Rome, they were king-makers for several decades before directly seizing power. Although they succeeded in driving the Franks out of Palestine in 1291, they were eventually eliminated by the Ottoman Turks, who then took over most of the Muslim realms in the Near East and North Africa. 
Kitbogha, was killed. Conflict from within preoccupied the Mongols so that they retrenched, and did not invade Palestine again. The Horde had been stopped, but at great cost to the Muslims and the Byzantines. Only Western Europe was left unscathed.

\section{The End of Latin Palestine}

Within a month of the battle at 'Ain Jalut, the victorious Mamluk general, Kutuz, was murdered and his successor, Baibars, quickly seized power. Baibars immediately violated a truce that he had negotiated with the Franks and invaded Palestine in 1263. Before his death in 1277, he retook most of the interior of Palestine, including the Templar castle of Safad and the Hospitaller fortress of Beaufort. Safad, it was said, was taken through the treachery of an Arabic speaking Syrian sergeant named Leon Cazelier.49 This indicates that the poulains were still a necessary, but greatly mistrusted, group within the Order.

Baibars' successors continued his campaigns against the Franks until the fall of Acre in 1291. The Mamluks had been noted for their fanaticism in battle since Saladin had begun using them in his armies. This martial spirit kept them in power for several generations, before their dynasty succumbed to the Ottoman Turks. 50

The last Grand Master of the Temple to rule in Palestine was Guillaume de Beaujeu. He was elected to the office in 1273. He arrived in Palestine in 1275,

49 Malcolm Barber, The New Knighthood, 167. Baibars violated his word to grant the Templars safe passage, had them decapitated, and sold their Syrian camp followers into slavery. 50 Robert Irwin, "Islam and the Crusades, 1096-1699," in The Oxford Illustrated History of the Crusades, 240-2, 246-50. 
after a two-year fundraising tour--not unlike Hugh de Payens'--in Europe. He was probably a veteran of the Sixth Crusade, had once been a prisoner of the Muslims, and supported the Capetian dynasty in France. The Temple's ties to France were stronger than they were to any other country at this time--even the Kingdoms in Spain and Portugal. The Templars hoped that the King of Sicily, who was related to the King of France, would provide them with the material and political aid which they so desperately needed at this time. Thus, electing De Beaujeu was a clear political signal to the Capetians that the Temple was pro-Angevin in its sympathies, and therefore worthy of support. 51

De Beaujeu was not a young man when he was elected (he was in his sixties when he died in 1291), but he was remarkably flexible in his dealings with the Muslims. His entire career as Grand Master was dominated by politics: Palestinian, French, Sicilian, Tripolitan, and Cypriot. At the same time that the Templars were dealing with the Muslims, they were also supporting the ambitions of the Angevin Charles of Anjou against Frederick II's descendants in Sicily, quarreling with the King of Cyprus, engaging in a civil war with the Count of Tripoli, and negotiating the sale of Maria of Antioch's claim to Jerusalem to Charles.

In the late 13th century, Western Europe was turning its attention back in on itself before its final expansion began in the early 16 th century. The Albigensian Crusade had only been a harbinger of the isolationism that would follow. The truly destructive civil wars--the Hundred Years War, the War of the Roses, the witchcrazes, and the Reformation--had yet to occur. Western Europeans could afford such a period of cultural and religious cannibalism because the Byzantine and various Muslim realms still buffered them against the invasions from Central Asia. Yet, at the same time, these powers were too 
weak and distant to pose any great threat to Western Europe. In light of this, Frankish Palestine seems more to have died of neglect rather than through any

active intervention of the Muslims. The Mamluks simply dealt the deathblow to a frontier that no longer primarily occupied the minds of Europeans.

Neither the Franks in Palestine, nor Latin Christians back home recognized this yet, however. They continued, sporadically, to plan crusades in which the military orders showed less and less enthusiasm. This led to increased criticism from Europe that the military orders did not want to win back the Holy Land. Previously, the reason given (by William of Tyre) had been that the military orders had, like the Italian city-states, prolonged the conflict in order to profit from it. Now, darker reasons were given. People began to say that the military orders (the Templars were used as the primary example) were secretly in league with the Muslims. In fact, the charges brought against them during the Trial were derived, in part from common European misperceptions about Islam. 52

Although they wanted to retake their lost territory as much as their comrades back home, the military orders were coming to realize that the Mamluks were much more powerful, and better organized, than the Muslims had ever been before. Saladin had done considerable damage. Still, he was only one man, and he had been unable to establish a permanent dynasty. The Mamluks had succeeded where Saladin had failed, and their defeat would require much more manpower than the Franks had ever been able to muster in the past. Wiser heads among the Palestinian Franks began to suspect that

52 Norman Daniel, Islam and the West: The Making of an Image (Edinburgh: The University Press, 1960; reprinted 1962), 114; for the relation of the charges to stereotypes about Islamic practice, see pgs. 357 and 368-9.; Helen Nicholson, Templars, Hospitallers and Teutonic Knights, 74, 126-7. 
the Holy Land would soon be lost.

Guillaume de Beaujeu stood at the center of the firestorm of criticism that assailed the Templars in the 1270's and 1280's. It was his controversial policy of treating with the Mamluks, and cultivating a network of Muslim sources of information, that drew the greatest charges of treason down on the heads of the Templars.

De Beaujeu's reputation--deserved or not--would cast him as a Cassandra in the final tragedy of the loss of the Holy Land. By the late 1280's, it was becoming increasingly clear that the Sultan of Egypt was only looking for an excuse to rid Palestine of the Franks. This excuse soon presented itself.

In August 1290, a group of newly arrived crusaders massacred Muslim traders in Acre. Kalavun, the Sultan of Egypt, demanded satisfaction. De Beaujeu suggested that the culprits be handed over to the Sultan, since Christian justice had already sentenced them to death, but his proposal was rebuffed. The Sultan immediately decided to march on Acre. De Beaujeu negotiated a last minute settlement with the Sultan, but this, too, was rejected unanimously by the Christians at Acre. De Beaujeu was perceived as being too heavily arabized to be trusted.

Kalavun died in November of 1290 . His son, al-Ashraf Khalil, attacked Acre the following April. The siege lasted from the 5th of April until the 28th of May, when the Templar fortress fell to the Mamluks. All of its inhabitants were killed. After Acre fell, the rest of the Templar fortresses quickly evacuated. There were no more troops with which to defend them. With the desertion of 'Atlit, the Templars' great castle on the coast, the Franks were driven completely out of Palestine. 53

Guillaume de Beaujeu had been killed during a surprise attack by the 53 Maicolm Barber, The New Knighthood, 175-8. 
Muslims on the 15th of May. As he was carried back into the Templar fortress, mortally wounded, some Christians jeered at him for fleeing the field. His last recorded words described his Order's distress as well as his own: "Seignors, je ne peus plus, car je suy mort; veés le cop. (Sirs, I can no more, because I am dead. See the wound.)." 54

\section{Aftermath}

The years between 1291 and 1307 were a period of consolidation and retrenchment for the Templars. Although the military orders had lost the Holy Land, they still possessed the great networks of manorial holdings and privileges which had fueled their perpetual crusade. The Spanish frontier was also a consideration. Even as Acre was falling, the Christians were gaining considerable ground in the Iberian peninsula. For the first time, in the 14th century, the Spanish Christians had to deal with a large minority of subject Muslims in their realms.

The Templars, themselves, still had footholds in the eastern Mediterranean. Although they lost the island of Ruad, just off the coast, in 1302, they continued to hold power in Cyprus. Cyprus had originally been a Templar possession, given to the Order in 1191 by Richard I of England in payment for a loan. The Templars had lacked the manpower and inclination to hold the entire island, and had been forced to give it back. They had, however, retained great holdings and considerable power over local politics over the

54 The Templar of Tyre, "Chronique du Templier de Tyr," in Les Gestes des Chiprois: recueil de chroniques francaises [The deeds of the Cypriots: a collection of French chronicles], ed. Gaston Raynaud (Genève: Imprimerie Jules-Guillaume Fick, 1887), 250. 
ensuing century. 55 They continued to meddle in Cypriot royal affairs right up until the Trial. This proved to be a mistake after they were arrested.

The politics of the Temple were quite conservative following the fall of Acre. Initially, the Marshal of the Temple, Theobald Gaudin, survived Acre to be elected Grand Master soon after. He disappeared from the historical record about a year later. Jacques de Molay, last Grand Master of the Temple, replaced him sometime in 1293. De Molay was a man in his 50's, at the time. He was a Frenchman, a knight in the noble, chivalric mold--illiterate, aggressive, and unsubtle. He also trusted his King, Philip IV, far too much.

The Templars, and the Hospitallers, were the focus of an intense debate over the future course of the Crusades. The Franks did not yet realize that they had lost the Holy Land permanently. Jacques de Molay was deeply involved in negotiations for a new crusade, and actively campaigned for one right up until the Trial. He was in France on a support drive for this when he was arrested.

De Molay was cautious, however, about attacking Palestine with too few troops. He appears to have felt that a half-hearted effort would be worse than no crusade at all. He advocated an international assault on Egypt. Others favored a thoroughgoing reform of the military orders. Some even advocated merging the Temple and the Hospital, a proposal that the members of neither order supported. Ramon Lull, an enthusiastic supporter of peaceful conversion of the Muslims (with some lapses into crusading fervor) supported the idea of merging the orders under a Bellator Rex, a Warrior King. Lull thought that Philip IV, or one of his sons, would fulfill this role perfectly. Philip thought so, too, although he never went on crusade, and the Templar funds

55 Peter W. Edbury, The Kingdom of Cyprus and the Crusades, 1191-1374 (Cambridge: Cambridge University Press, 1991), 7-8, 77-8. 
which he later confiscated for the proposed crusade were squandered on his endless debts. 56

De Molay was not adverse to the concept of a Warrior King. In fact, he advocated having a leader of the new crusade who would not be a Templar or a Hospitaller. This was to avoid conflict with the Genoese and the Venetians, who saw the Temple and the Hospital as dangerous economic rivals. 57 In this, De Molay showed good sense. So focused was he upon the proposed crusade, however, that he ignored other, very dangerous developments occurring in the heart of the Templars' beloved France.

Philip was chronically in debt. Historians still debate whether this insolvency was due to Philip's fiscal carelessness, or whether it went back to Louis IX's crusade. Either way, Philip was a monarch in perpetual pursuit of funds. To this end, he despoiled and expelled the rich Italian bankers (called 'Lombards'), upon whom he depended for loans in 1291 and 1311, and the Jews in 1306 . He taxed the clergy, and repeatedly debased the coinage of the realm, provoking retaliation in kind from his enemies in the Low Countries. 58 In this way, he financed foreign ventures against the countries on his border.

Philip also believed himself to be, or projected the image of being, a most Christian King. He saw himself as Saint Louis' successor in reputation as well as body. His councillors capitalized upon this self-image, his chief minister (and Keeper of the Keys) Guillaume de Nogaret in particular. In 1308, the Bishop of Troyes was tried for using witchcraft to kill the Queen, Jeanne de Navarre, in 1305. In 1310, a persecution of the Beguines (a radical branch of

56 J.N. Hillgarth, Ramon Luil and Lullism in Fourteenth-Century France (Oxford: Clarendon Press, 1971), 105-6.

57 Malcolm Barber, The New Knighthood, 293.

58 John H. Munro, "Bullionism and the Bill of Exchange in England," in The Dawn of Modern Banking, 189. 
the Franciscans) ended with the burning of their leader (a woman) for heresy. Her specific crime was daring to write a book on religion, called The Mirror of Free Souls. 59 This fear of sorcerous and heretical attacks upon society and the royal family did not evaporate with Philip's death that same year. Instead, it grew and intensified as France spiraled into the Hundred Years War.

In 1303, Guillaume de Nogaret orchestrated an attack on Pope Boniface VIII, at Philip's behest. Boniface was aggressive and high-handed. Like Gregory VII and Innocent III, he believed that the Church's temporal power should match its spiritual influence. Boniface had clashed for nearly a decade with Philip over Philip's taxation of the clergy. He died only a month after the attack.60

Emboldened, Philip also harassed the next Pope, who died soon after his election, then pushed through his own candidate. This man, Clement $\mathrm{V}$, removed the Papacy from Rome and settled in the town of Avignon, just outside the French border. Clement had good intentions, but had put himself into a vulnerable position in Avignon. He was also chronically ill (stomach cancer would kill him shortly before Philip's death), and he felt beholden to Philip for his position. His weakness would soon prove disastrous for the Templars.61

Guiliaume de Nogaret, Philip's chief minister, was a dangerous and unstable man. He was a non-noble who had studied law and had risen rapidly in the King's service. He owed all of his good fortune to Philip. He acquired enormous holdings in Langedoc (in southern France), and soon became the

59 Barbara Tuchman, A Distant Mirror: The Calamitous 14th Century (New York: Alfred A. Knopf, Inc., 1978), 317.

60 Félix Rocquain, "Two Hostile Sovereigns at the Brink," in Philip the Fair and Boniface VIII: State vs. Papacy, ed. Charles T. Wood (New York: Holt, Rinehart and Winston, 1967), 47-52. $61 \mathrm{G}$. Mollat, The Popes at Avignon, 1305-1378, trans. Janet Love (Thomas Nelson \& Sons, 1963, reprint 1965), 5-8. 
largest landholder in that region. Rumors abounded, possibly because his birthplace was near Toulouse, that he was descended from executed Cathars and that he was obsessed with black magic. Some even accused him of practicing sorcery against his enemies. He was continually at odds with his neighbors, both great and small, and had numerous lawsuits in motion at any given time.62

Whatever the truth of such rumors, De Nogaret was clearly enamored of a certain type of legal charge. He prosecuted both Boniface VIII and the Bishop of Troyes for witchcraft, and wrote the charges against the Templars.

Some historians have suggested that De Nogaret manipulated Philip into destroying the Templars, and into committing other crimes, but the relationship between King and councillor appears to have been more symbiotic than parasitic. Philip gave De Nogaret the power to do the King's will, and De Nogaret soon learned how to manipulate Philip's fears by creating a certain type of accusation against his victims. Philip, however, appears to have been fully in control of De Nogaret throughout the Trial.

\section{The Trial}

In September of 1307, Philip sent out secret orders to his vassals and officers to prepare for a mass arrest of the Templars. This arrest was carried out at dawn on October 13. The five main charges were: that the Templars 62 Franklin J. Pegues, The Lawyers of the Last Capetians (Princeton: Princeton University Press, 1962), 99-102. It is interesting to note that the 17th century Puritan society in New England, which was obsessed with witchcraft and heresy, was riddled with lawsuits. Many accused witches in Colonial America were as litigious as De Nogaret. They had long histories of successfully suing poorer neighbors for slander, and over property, before they were ever brought to trial for witchcraft; Carol F. Karlsen, The Devil in the Shape of a Woman: Witchcratt in Colonial New England (New York: W.W. Norton \& Company, 1987), 57-60. 
denied Christ, that they desecrated the Crucifix, that they worshipped idols, that they engaged in homosexual relations with each other, and that they gave each other ritual obscene kisses. Three of the charges--the denial, the desecration, and the obscene kisses--were claimed to be part of the Templars' initiation ceremonies for new members. 63

Initially, Philip enjoyed great success in his endeavor. Most of the Templars in France were captured in the initial arrest. Philip's baillis were able to elicit confessions from most of the imprisoned Templars, including the Grand Master himself. The earliest confession occurred only days after the arrest.

Philip immediately sent word of the Trial to the other Christian realms. His royal peers reacted with little enthusiasm. In England, Edward II allowed many Templars to slip through his net, and initially prohibited the use of torture. Since the confessions in France had been elicited using intense torture techniques, results in England were unspectacular. Philip eventually sent a group of Dominican monks to take charge of the investigation. The Dominicans bullied Edward into allowing torture, but the prosecution in England remained largely unsuccessful.64

In Germany, the local authorities were so sympathetic to the Templars, or so intimidated by them, that they made no arrests (except in Magdeburg, where the Archbishop was excommunicated by the Bishop of Halberstadt for his excessive zeal in trying the case), and the local Templars continued to live unmolested until the Order's suppression. In Naples, Philip's uncle, Charles II, elicited results similar to those in France. The Papal States produced mixed results. Lombardy and Portugal found all of their Templars innocent.65

63 Malcolm Barber, The Trial of the Templars, 45-6.

64 Ibid., 193-204.

65 lbid., 213-6. 
James II of Aragon initially refused to prosecute the Templars in his realm. By December of 1307 he had changed his mind--either because he feared Philip or because he desired the Templars' possessions. Unfortunately for him, the Templars had been forewarned of his intentions and he was forced to lay siege to their fortresses for nearly a year. They enjoyed popular support and were eventually exonerated, although James did acquire much of their property. 66

In Cyprus, the Temple was vigorously prosecuted by the King, Henry II, who was hostile to the Order. Many Templars died under torture. Records are incomplete, however, and the final fate of the surviving prisoners is obscure. 67

In addition to the lack of enthusiasm among the other Christian monarchs, Philip ran into resistance from Clement. The Pope was upset that Philip and De Nogaret had brought proceedings against the Order (whose members were technically answerable only to Clement) without his prior knowledge. This created two problems. First, the threat existed that Clement would dismiss the entire Trial. Second, Clement's protests would contradict the assertion of the King and De Nogaret that the arrests had been made with the Pope's prior knowledge and approval. Both problems threatened the legitimacy of the Trial proceedings.

Philip was able to bring Clement partially under control by reviving the proceedings against Boniface. Clement was frightened into acknowledging the legitimacy of the Trial, but insisted on taking control of it, himself. This created an inconvenient resistance among the Templar prisoners. Nearly 600 organized a defense of the Order before the Pope. Philip crushed it by burning 65 Templars as relapsed heretics in May of 1309.

66 A.J. Forey, The Templars in the Corona de Aragón , 359-62.

67 Peter W. Edbury, The Kingdom of Cyprus and the Crusades, 136. 
The Pope continued to vacillate, but the King was adamant. Finally, on March 22, 1312, Clement officially suppressed the Order with the Papal Bull Vox in excelso at the Council of Vienne. The majority of the bishops, surrounded by French troops, voted in favor of the Pope's action. The Templars' property was transferred to the Hospitallers, who had difficulty actually acquiring it for years to come. The French crown, in particular, plundered as much as it could before turning any Templar property in its possession over to the Hospital. Eventually, the Hospital had to bribe the French government to give up the property. 68

It was the final act of the Trial which would set the stage for the legends that the Templars have survived to this day. On March 18, 1314, Jacques de Molay, Geoffroi de Charney, the Preceptor of Normandy, and two other high Temple officials were brought out to confess their sins in public ceremony, before being sentenced to perpetual imprisonment. The other two repeated their confessions without incident. De Molay, however, finally rebelled and recanted his confession, shouting out the Order's innocence. De Charney joined him in repudiating his own confession and defending the Order. The King immediately ordered that they both be burned at the stake. They died protesting their innocence and the innocence of the Order.

By the end of the year, both Clement and Philip were dead. Within 15 years of De Molay's execution, the Capetian line--which had survived in an unbroken line of sons for over four centuries--became extinct. All four of Philip's sons died young and without direct heirs. This strange progression of events gave rise to legends attributing the Capetians' misfortune to De Molay's dying curse. As he burned, De Molay, so the tales said, called the Pope and the King to divine judgment within the year, and cursed the 68 Malcolm Barber, The Trial of the Templars, 232. 
Capetian line, itself.69 These legends, like De Nogaret's charges, persist to this day.

\section{Historiography}

The historiography of the Knights Templar is long, complex, and generously laced with fiction and legend. It overlaps with the historiographies of: The Masonic Temple, the myths of the Grail, and the legends surrounding somewhat more concrete relics, such as the Shroud of Turin, and the splinter of the True Cross, which was captured by (and disappeared under) Saladin. A good rule of thumb for the Templar historian is to view with great skepticism any document which claims to chronicle the survival of the Templars following the burning of their last Grand Master in 1314. Most of these documents date from the late 17th century onward. They purport to be written records of oral traditions dating back to the 14th century and have more to say about the rise of the Freemasons and Romanticism than they do about the medieval Templars. 70

Several contemporary writers at the time of the Trial, and later in the 14th century, mentioned the Templars. Those sources that were not French tended to be sympathetic. Italian writers like Dante and Bocaccio portrayed them in an especially good light. Dante scholars believe that Dante was attacking Philip the Fair, more than supporting the Templars, in his reference to the Trial, when

69 Barbara Tuchman, A Distant Mirror, 44.

70 Peter Partner, The Knights Templar and Their Myth, 80, 89-114. For an example of what types of sources Templar survivalists generally use, see Michael Baigent and Richard Leigh, The Temple and the Lodge (New York: Arcade Publishing, 1989), 271-99. Baigent and Leigh's notes and bibliographical sections are full of "definitive" medieval sources which are actually Masonic family documents dating from the 18th and 19th centuries. 
he placed Philip in Hell.71 Dante resented Philip for invading northern Italy, and used the Trial as a symbol of his rapacious appetite for power.

Historiographically speaking, the Templars dropped out of sight for the next few hundred years after their fall. Those Templars who had survived the Trial experienced a variety of fates--some (in Cyprus, Germany and Italy) were absorbed into the Hospitallers and Teutonic Knights. Many others (mostly in France) were scattered to various monasteries in ones and twos. In Spain, some were absorbed into the various secular military chivalric orders which had sprung up in imitation of the religious military orders. Others went over to the Muslims. Finally, in Portugal, the Templars and Hospitallers were merged into one secular group of knights, who still referred to themselves as Templars in the 16th century. Through this process of assimilation, the. Templars were mostly forgotten for the next three centuries.

In 1666, Thomas Fuller mentioned the Templars (not favorably) in his crusades history: A History of the Holy Warre. Fuller used them as an example of the worst excesses of the Catholic Church and attributed their fall to pride.72

When the Freemasons began in 1717, they quickly claimed the Templars as their ancestors. Various splinter groups even claimed direct descent from the original Templars--through an unbroken line of Grand Masters blessed by Jacques de Molay, himself. Some historians have seen this as an attempt by bourgeois leaders of the Freemasons to claim aristocratic privileges for

71 Paget Toynbee, A Dictionary of Proper Names and Notable Matters in the Works of Dante (Oxford: Clarendon Press, 1968), 271-2, 602. Dante Alighieri, La Divina Commedia (Cambridge: Harvard University Press, 1972), Canto XXI, v. 87, p.190, and Purgatorio Canto XX, v. 90-3, p. 489.

72 Thomas Fuller, A History of the Holy Warre (London: William Pickering, 1840; reprint, Cambridge, 1639), 242-7. Fuller, as an English Protestant writing during the reign of Charles I, used the Trial to attack both the Papacy and the French Monarchy. 
themselves. 73

A revival of interest in the Middle Ages--and chivalry, in particular--gripped Europe during the 17th and 18th centuries. In this nostalgic mood for the past (which Cervantes ridiculed in Don Quixote) people conveniently forgot about the true horrors of medieval life and longed for the days when men had been heroes. Because the secular military orders still revered them, the Templars now became models of chivalry. 74

At the same time, however, Europe experienced an interest in other cultures. The Enlightenment was an age of exploration, both mental and physical. Scientists were making new discoveries and inventions. Sailors, soldiers, and merchants were exploring previously uncharted and legendary parts of the world. Curiosity about other lands was higher in European culture than it had ever been.

One of the areas that fascinated Europeans most was the relatively close region of the Middle East. Since their ancestors had connected heresy with sorcery, and both with Islam, Enlightenment era Europeans became obsessed with the supposed occult secrets of the Near (and Far) East. Because of their role in the Crusades, and their subsequent suppression as idol-worshipping heretics, the Templars were perceived as possessing occult Oriental secrets. These two currents of thought (Templars as models of Chivalry vs. Templars as crypto-Islamic heretics and sorcerers) have mostly managed to ignore each other for the past three hundred years. They continue to do so today. They 73 See Partner for an informative and entertaining (albeit too brief) account of the growth of the Templar legend. Partner spends little time trying to determine why these groups reinvented the Templars the way they did and his book is too short to be comprehensive. Still, it is an excellent overview of the neo-Templars and, so far, the only legitimate scholarly overview available on the subject. See, also, Desmond Seward, The Monks of War for an account of the rise of both the religious, and secular, military orders. See The Military Orders From the Twelfth the Fourteenth Centuries, by Alan Forey, for an examination of specific issues relating to these orders.

74 Paul J. deGategno, Ivanhoe: The Mask of Chivalry, Twayne's Masterwork Studies no. 125, (New York: Twayne Publishers, 1994), 8, 21. 
comprise the two extremes of Templar historiography.

Sir Walter Scott's two Templar novels: Ivanhoe (1819) and The Talisman (1825) helped pique public interest in the Templars. These were not

sympathetic portraits of the Order. Scott depicted a corrupt and unscrupulous organization bent on world domination. Scott played with the facts in his novels--having a Saxon character who reverted to paganism at her death calling on Slavic gods, for example, but he still created a compelling portrait of the Crusades era. $75 \mathrm{He}$ also constructed two contradictory, but indelibly bad, images of the Order in the brave but corrupt Templar preceptor, Sir Brian de Bois-Guilbert and the pure but fanatical Grand Master, Lucas de Beaumanoir.

A year before Ivanhoe was published, J. von Hammer-Purgstall published an article called "Mysterium Baphometis revelatum" [The Mystery of Baphomet Revealed], in which he postulated that the Templars had worshipped a fertility idol called 'Baphomet.' Hammer-Purgstall also connected them to the Cathars and the Gnostics. Baphomet is now known to be a corruption of the name 'Muhammad.' Many modern writers, especially novelists, still propagate the idea that a group of gnostic, idol-worshipping Templars has survived to the present day.

Umberto Eco's Foucault's Pendulum (1988), for example, is a story about three Italian editors who--as a joke--invent a secret, Templar/Gnostic world conspiracy which soon takes on a life of its own. Eco does not take the idea of a 700 year old conspiracy nearly as seriously as some non-fiction writers on the subject, and his protagonists agree.76 Unfortunately for them, they are soon caught up in a fatal, neo-Templar conspiracy woven around their tall tale

75 Sir Walter Scott, Ivanhoe: A Romance (Philadelphia: Porter and Coates, 1830, reprint (originally published 1819), 263.

76 Umberto Eco, Foucault's Pendulum, trans. William Weaver (New York: Ballantine Books, 1990), 57-8. 
by pseudo-mystical fanatics who will kill for the editors' non-existent secret. In the end, the editors' cleverness offers them no protection against the stubborn madness of people who will believe in anything to avoid believing in nothing.

In the 1830's and 1840's, two series of books injected some historical facts into the debate. The first, Le Procès des Templiers [The Trial of the Templars], a two volume series of unedited documents from the Trial in France, was edited and published by J. Michelet in 1841. The second, $\underline{\text { Recueil des }}$ Historiens des Croisades [Collection of Historians of the Crusades], a 16 volume series (printed in the non-traditional format of $12 \times 18$ inches), comprised of Laws, and chronicles on the Crusades written by contemporary Eastern, Western, Greek, and Armenian historians, was published throughout the 1840's. These volumes included: Lois [Laws], vol. 1-2, Historiens Occidentaux [Western Historians], vol. 1-5, Historiens Orientaux [Eastern Historians], vol. 1-5, Historiens Grecs [Greek--Byzantine--Historians], vol. 1-2, and Historiens Arméniens [Armenian Historians], vol. 1-2.

The first important history following these publications was Charles Addison's A History of the Knights Templar. Addison had Masonic connections, even adding a section on the current (for 1850) state of Freemasonry--as well as Masonic advertisements--at the end of his book. Addison believed, without question, in the Freemasons' claims of unbroken descent from the Templars, and declared himself a member "of the Inner Temple."77 Addison enthusiastically supported St. Bernard's vision of the Templars as fanatical warriors, devoted to killing every non-Christian who took up arms against their religion. 78

In the late 1800's and early 1900's, it became popular for local historical 77 Charles G. Addison, The History of the Knights Templars, the Temple Church, and the Temple (Kempton: Adventures Unlimited Press, 1997; reprint, London, 1842), title page. 78 Ibid., vii. 
societies and Masonic groups to compile, and translate, surviving cartularies of various medieval groups--the Templars among them. These collections were amateur affairs-- filled with printing errors, badly bound, and printed on cheap, acidic paper that has not survived the past century well. Collections included cartularies of: Dauphiné, Douzens, Eure-et-Loire, Puy-en-Vélay, Provins, Richerenches, Sommereux, Vaulx, and Vaour/Tarn (France), Catalonia and Huesca (Spain), Sandford (England), Malta, and several general cartularies comprised of documents from various areas. Some documents have also been culled from the cartularies of the Hospital. Far fewer exist than should, however, considering that the Hospitallers eventually took over the bulk of the Templar properties. What happened to these legal documents is one of the many mysteries surrounding the disappearance of the Templar archives.

The Rule of the Order (which has survived) was also edited and annotated, in 1886, by Henri de Curzon. A modern French translation was published in 1978 by Laurent Dailliez. Curzon's has been the definitive edition of the Rule until recently. An English translation by J.M. Upton-Ward partially superseded it in 1992.

With all of these new primary sources, it seemed logical that the historiography on the Templars would expand dramatically. Indeed, it did. While preparing his Bibliographie du Temple in the 1970's, Laurent Dailliez consulted over 5,000 sources. 79 As new documents are slowly dug up, interest in the Templars continues to grow, rather than shrink. This is in contrast to the other military orders (The Hospitallers, the Teutonic Knights, the Knights of Lazarus, and the secular orders) whose historiographies have

79 Laurent Dailliez, Bibliographie du Temple (Paris: Diplômé de l'Ecole Pratique des HautesEtudes, 1980?), 4. 
been dramatically overshadowed by the historiography of the Templars.

Beginning in the 1930's, with G. Campbell, some historians tried to balance their views of the Templars more than before. Campbell was sympathetic to the Templars, but refused to idolize them as wonders of Chivalry. Because of this, Campbell could examine, and debunk, some of the darker myths that had grown up in the shadow of the Templar legend. He did not believe that the Templars had been either heretics, or sorcerers. Nor did he believe that their dealings with the Muslims had necessarily been treasonous, nor that these dealings had led to the fall of the Latin Kingdom in Palestine.80

E.J. Martin, in The Trial of the Templars, on the other hand, believed implicitly in the corruption of the Templars. The crux of his argument rested on his belief that what the Templars had said under torture could be trusted as the absolute truth. $81 \mathrm{He}$ did not believe that they had been coerced at all. Most of the 70-odd pages of his short history expanded on the charges and confessions made during the Trial. Martin's book was written in the late 1920 's, when the tactics that the Gestapo and the GRU (later, the KGB) used to wring outrageous confessions from their victims were still little known--let alone understood.82 Thus, Martin might be excused for his naiveté concerning the effects of torture techniques on the search for truth. Some later historians, such as G. Legman in The Guilt of the Templars (1967), proffered the same argument when they should have known better.

This disturbing tendency for some historians to believe medieval accounts

80 G.A. Campbell, The Knights Templars: Their Rise and Fall (London: Duckworth, 1980; reprint, London: Duckworth, 1937), 198-210.

81 Edward J. Martin, The Trial of the Templars (London: George Allen and Unwin Ltd., 1928; reprint, Cleveland: AMS, 1978), 62-3.

82 William Sargent, Battle For the Mind: A Physiology of Conversion and Brain-Washing, (Garden City: Doubleday and Company, 1957), 208-18. See also J.A.C. Brown, Techniques of Persuasion: From Propaganda to Brainwashing (Middlesex: Penguin Books, 1963), 285-93. 
of confessions obtained under torture is an example of how historians may suppress unpleasant facts that contradict their theories. There is ample evidence that the elements of the Templars' confessions followed a set of questions and answers prearranged by the torturers. Modern studies of torture show that almost anyone can be made to confess to--and even manufacture false memories of--any crime.83

Martin (like some French historians) wanted to justify Philip IV's suppression of the Templars. 84 Legman, and his co-contributors, wanted to prove that the Templars were crypto-Cathars and neo-pagans, who died to protect their religion. Legman's book is confusing because neither he, nor his collaborators seem certain of their conclusions.

Legman begins the book convinced that the Templars were guilty. $\mathrm{He}$ is not sure, however, of what, exactly, they were guilty. He eventually determines from the Trial confessions (which he takes completely at face value) that the Templars had engaged in regular (and possibly, ritualistic) homosexuality, coarse horse-play involving kissing games, and usury. 85

It is highly unlikely that the Templars were Cathars of any type. The Cathars emphasized humanity's spiritual nature over its material ties. They saw the physical world as being the realm of the Devil. They abhorred bloodshed, including the eating of meat.

The Templars, on the other hand, were very firmly rooted in the temporal world by their possessions and their territorial concerns. They had little room for the spiritual or mystical. The Rule clearly discourages the ascetic and contemplative practices of both the mainstream monastical orders and the

84 Edward J. Martin, The Trial of the Templars, 26-7.

85 G. Legman, The Guilt of the Templars, (New York: Basic Books, Inc., 1966), 19-26, 51. 
heretical Cathars (\#15). 86 Such methods might save the soul, but the Templars knew from experience that they weakened the body and rendered it unfit for physical battle. The last monastic Order which would welcome the ideas of the Cathars would be a military one. In hindsight, it is not remarkable that the Dominicans (who were created as a mirror-image and scourge of the Cathars) would become the natural enemies of the Templars.

Historiography on the Templars took a more rational turn in the 1970's and 1980 's with the publication of several books. These works either treated the military orders in general (Desmond Seward's The Monks of War), described the Order as a whole (Alain Demurger's Vie et mort de l'ordre du Temple The Life and Death of the Order of the Temple] in 1985), dealt with the Trial (Malcolm Barber's The Trial of the Templars), or covered some regional aspect of the Order (A.J. Forey's The Knights Templar in the Corona de Aragon). Ann Gilmour-Bryson published The Trial of the Templars in the Papal State and the Abruzzi, the first in-depth analysis of the Trial documents from Italy. M.L. Bulst-Thiele produced Sacrae Domus Militiae Templi Hierosolymitani Magistri The House of the Holy Militia of the Masters of the Temple of Jerusaleml in 1974. This book took a biographical look at the Masters of the Order throughout its known history.

In the 1990's, attention turned to the Templars' external, contemporary image (Helen Nicholson's Templars, Hospitallers and Teutonic Knights: Images of the Military Orders, 1128-1291). J.M. Upton-Ward produced a longawaited English translation of the Templar Rule in 1992. This translation is often used, although some historians were disappointed that its explanatory 
text is less extensive than Henri de Curzon's 1886 edition. 87

Two veterans in the field also published overviews of the Order during the 1990's. A.J. Forey collected several of his previous articles on the Templars in his book Military Orders and the Crusades in 1994, including one which discussed the possible existence of female Templars. ${ }^{88}$ Malcolm Barber wrote The New Knighthood: A History of the Order of the Temple in 1994. This volume includes a chapter on Templar survivals, an historiographical postscript and a bibliography that gives a good, representative sampling of the historiography of the subject. 89

87 Simon Lloyd, review of The Rule of the Templars: The French Text of the Rule of the Order of the Knights Templar (translated by J.M. Upton-Ward), in The Journal of Ecclesiastical History 44 (April 1993): 337-8.

88 Alan Forey, "Women and the Military Orders in the Twelfth and Thirteenth Centuries," in Military Orders and the Crusades (Aldershot: Variorum, 1994), 63-92.

89 For a more inclusive bibliography, see Laurent Dailliez's Bibliographie du Temple (1976). There is no complete bibliography of all books published about the Templars in existence. 


\section{CHAPTER THREE: THE CRUSADES: AN OVERVIEW}

\section{The Idea}

The most remarkable thing about the Crusades over the past 900 years is the continued insistence of both Muslims and Christians that this bloody period of history was a war between good and evil--one that remains unresolved to this day, regardless of which side historians take. The urge to search for a side to favor is almost irresistible. Yet, there was little good sown by the actions of either side, and an appalling crop of evil for both.

Like a few other conflicts that began in the Middle Ages (such as the Hundred Years War, or the Anglo-Irish conflict) the Crusades have continued in spirit--and sometimes, in fact--far beyond the fall of Acre in 1291 (the traditional end point for Palestinian Crusades historiography). 1 When all the pious prayers and cries for Crusade or Jihad are stripped away, the true purpose of this conflict is laid bare. In the end, the Crusades were about revenge.

\footnotetext{
1 The latest conflict began with the bombing of the U.S. Embassies in Nairobi, Kenya and Dar Es Salaam, Tanzania in 1998. This conflict, instigated by a group calling itself "The Islamic Holy Front in the War Against Jews and Crusaders," has barely begun. Many of the victims of the bombings were Muslim and most of them were descended from people who never participated in the Crusades.
} 
The Crusades can be divided into two fronts: Palestine and Spain.2 The first front began in 1099, and crumbled before the Muslims at Acre in 1291. Descendants of the Frankish Crusaders won back the entire region early in the 20th century, leaving it in chaos. Currently, most of the former Crusader kingdoms lie in the volatile hands of the Jewish Israelis, which many Muslims resent as a European, colonizing force. ${ }^{3}$ No one can predict how this latest stage of Palestine's history will play out.

The second front began immediately after the Muslim conquest of Spain. Charles Martel, palace chamberlain for the Frankish Merovingian kings and the grandfather of Charlemagne, destroyed a Muslim raiding party at Tours, in central France in 732. Seven and one half centuries later, King Ferdinand of Aragon and Queen Isabella of Castille would take the last of the Muslim cities, Granada, in the summer of 1492 . That same summer, they sent an Italian adventurer, Columbus, off to explore the New World and initiated a successful purge of all non-Christian elements in Spain. Ferdinand and Isabella's marriage had already unified the Christian territories under one crown. The brutal expulsion of Spanish Jews and the Muslims, begun in their reign, cemented the permanent Christian reconquest of the Iberian peninsula.

2 This paper only addresses the southern Crusades against the Muslims. The Northern Crusades made by the Latins were against pagans, and "heretics" (Byzantines, usually). Only one military order, The Teutonic Knights figured heavily in this contest. This conflict did not include the Templars to any great degree, nor did it involve the Muslims at all. The Russians also warred against the Muslims, but their conquest and recovery did not occur within the same time frame, nor did they have any cultural or political connection with either the Franks or the Spanish. In fact, the Russians were enemies of the Latins, and warred successfully against the Teutonic Knights. That military order continued to be regarded in Russia with hostility after the fall of the traditional monarchy and the rise of communism. For a Communist era cinematic portrait of the traditional Russian view of both the Teutonic Knights, and the Muslim Mongols, see Sergei Eisenstein, Alexander Nevsky, directed by Sergei Eisenstein, 110 min., 1938. 3 Fundamentalist movements on both sides of the Arab-lsraeli conflict drive the hostilities in Palestine; Niels C. Nielsen, Jr., Fundamentalism, Mythos, and World Religions, 93, 97. 


\section{The Rise of Islam}

Like the Byzantine Empire and the Latin Church, Arab civilization was an heir to the Roman Empire. While lying on the edge of the Roman orbit of power, the Arabian peninsula absorbed Roman and Greek culture for nearly a thousand years before the birth of the Prophet Muhammad. 4

Muhammad was born in Mecca, in 570 . The details of his early life are sparse. Orphaned early, he grew up to work caravans for a widow named Khadija, whom he subsequently married. He began to have visions at age 40 . Through these visions, he developed a system of monotheism. Muhammad derived much of his philosophy from contacts with Christians, Jews, and Zoroastrians. 5 During his lifetime, many Christian and Jewish religious communities--ranging from orthodox townspeople to ascetical sects--dotted the Arabian peninsula. The majority of Arabs, however, were polytheistic. 6

Muhammad believed that he was the latest in a long line of prophets. He also believed that the last prophet before him was Jesus, who, while born through immaculate conception, was not divine. There was no Christ, no Holy Spirit. Only one God (Allah) existed. Very few, besides Khadija, and his relatives and friends, believed him when he said that these visions came from God.

Muhammad was unable to attract many followers in Mecca. Mecca was an important religious community, even to the pre-Islamic Arabs. It contained

4 G.W. Bowersock, Roman Arabia (Cambridge: Harvard University Press, 1983; reprint, 1994), 10-11.

5 Zoroastrianism is a Persian religion which predates Christianity. Zoroastrians believed that two, equally powerful deities, one good and one evil, were engaged in an eternal contest for the world. This belief manifested itself as manichaeism (where Satan is as powerful as God) in Christianity. Although groups (like the Cathars) who openly espoused this belief were condemned as heretical from the 6th century on, manichaeism has remained a tacit part of Christian thought.

6 Philip K. Hitti, History of the Arabs, 106-7. 
numerous pantheistic and animistic shrines, and made the merchants of the city rich on the pilgrim trade. The leaders of the Meccan community felt threatened by Muhammad's opposition to idolatry; he and his followers were forced into exile in 622.7 Muslims later referred to this event as the hijra, or "flight" from Mecca.

Muhammad soon found refuge in a city to the north, called Yathrib. Here, he acquired many more followers than he had in Mecca. Eventually, Yathrib was renamed Al-Medinah (the city [of the Prophet]). After Mecca, it is the holiest city in Islam. Jerusalem is the third. From Medinah, Muhammad and his followers engaged in a successful trade war with Mecca, attacking Mecca's caravans and cutting off the flow of pilgrims. Muhammad lived to see Mecca taken by his followers before his death in 632.8

Following Muhammad's death, his successors embraced the concept of jihad (holy war), and spread out from the Arabian peninsula. They were aided by turmoil in the Byzantine and Persian Empires. These two empires had recently exhausted each other on the battlefield. Also, Byzantium had become increasingly rigid in its interpretations of orthodox thought, alienating many Christians in the outer provinces. When the Muslims came, they were able to take many of these provinces with little struggle. Soon, the Persian Empire had fallen and Byzantium had been greatly reduced, with relatively little slaughter.

The loss of Jerusalem in 638 shocked Christianity to its core. Christianity, already fragmenting in the wake of the fall of Rome, now definitively divided

7622 C.E. is year 0 in the Muslim calendar, which uses the designation A.H. (after hijra) for its dates. The Muslim year does not correspond exactly with the Gregorian (or its predecessor, the Julian) year, however, since the Muslim calendar is based on a lunar month of approximately 28 days. This is why Ramadan, like Easter and Passover, "floats" through the year. Unlike Easter and Passover, however, is has no self-corrective, since it is not based on any particular season. 8 Philip K. Hitti, Makers of Arab History (New York: St. Martin's Press, 1968), 4-18. 
into two parts--Roman and Byzantine. Initially, the Arab conquest affected Byzantium more than Europe, but with the invasions of Spain and Italy-beginning in 711---this soon changed. Religious and cultural life in the Mediterranean area was about to be turned upside-down.

The initial conquest of North Africa, Spain, southern Italy, and much of the Levant and Asia Minor, was not bloodless. Historians have often commented on the religious tolerance of early Muslim society, specifically toward Jews and Christians, who were called "People of the Book (The Bible)."9 The Arabs had also learned to respect literature, following the committing of the sayings of the Qu'ran to paper. In general, they preserved the libraries and culture of local communities. As long as conquered peoples respected the supremacy of the Muslim faith (whether or not they followed it) they were left to their own devices. 10

Yet, this tolerance had limits. The high rate of conversion in the first years after the conquest, despite Muslim leaders' initial efforts to keep Islam within the Arab community, indicates that dhimmis (non-Muslims under Muslim rule) had a low status in the new empire. Even the status of Christians and Jews, while better than Muslim or Jewish status in many Christian communities, or the status of pagans in Muslim communities, was restricted. Dhimmis were permanently barred from political power, and from active proselytization or public celebration of their own faith. Their safety depended on their perceived loyalties to the Islamic state and the whims of Muslim authorities. They could be punished severely if they mocked or imitated Muslims in dress or custom. Like the Jews in late Medieval Europe, they were required to wear distinctive

9 Frederick Mathewson Denny, An Introduction to Islam, 2d ed., (New York: Macmillan Publishing Company, 1994), 65.

10 S. Bashiruddin, "The Fate of Sectarian Libraries in Medieval Isiam," Libri 17 no. 3 (1967), 14950 . 
dress, easily singling them out for persecution. 11 In times of economic or social stress, their protected status melted away before the frenzy of the mob. 12

The prohibition from active recruitment was a death sentence for Christian communities (The Jews had already found some ways to discreetly flout such statutes). A century after the initial conquest, the morale of Christian communities in Muslim Spain had sunk so low that several prominent Christians demanded, and received, martyrdom from reluctant Muslim governors. 13 Nor did Muslim tolerance exist in a vacuum. In societies where Islam did not predominate, Muslims tended to absorb the tolerances, and intolerances, of the surrounding culture.14

Christian communities on the edge of the conquest also suffered confusion and disillusion. When the initial Muslim conquest smashed into southern Europe, many Christians felt that God had abandoned them to the Infidel. Even after the Muslims were stopped by Charles Martel at Tours, Muslim pirates continued to raid up the Aquitainian coast and along southern France and the coasts of Italy. Even the Byzantines, who had a large and sophisticated fleet of their own, were threatened by Muslim warships. 15 Sicily fell, and became a Muslim kingdom. All of northern Africa, the homeland of St. Augustine and many of the original ascetics and monastic communities,

11 "The Pact of "Umar," in The Medieval Record: Sources of Medieval History, trans. T.W. Arnold, ed. Alfred J. Andrea (Boston: Houghton Mifflin Company, 1997), 93-4.

12Thomas F. Glick, Islamic and Christian Spain in the Early Middle Ages (Princeton: Princeton University Press, 1979), 173-4.

13 Jan Read, The Moors in Spain and Portugal (London: Faber and Faber, 1974), 63-4. In Muslim Spain, Christians were called "Mozarabs." Later, under the Christians, the Muslim minority were called "Mudejars" or "Moors."

14 David Nirenberg, "Violence and Persecution of Minorities in the Crown of Aragon: Jews, Lepers, and Muslims before the Black Death," (Ph.D diss., Princeton University, 1992), 103-5. 15 Richard W. Unger, The Ship in the Medieval Economy, 600-1600 (London: Croom Helm Limited, 1980), 52-5. 
reverted permanently to Islam. Northern Europe was violently disassociated from Constantinople (although new trade routes, through the Muslims, were soon established). The Byzantine Empire survived, albeit greatly shrunken and weakened from its former state.

The demoralization was made worse by the almost simultaneous raids along the northern coasts of Europe by the Vikings, or Norsemen. So irresistible were the Norsemen that the Franks were forced to buy them off with land, and use them in the Carolingian armies. Eventually, Europe was able to survive through a self-imposed isolation behind the buffers of the crippled Byzantine Empire, the Mediterranean, and the Norse colonists. Since the Norse invasions had laid waste to the Carolingian Empire and most of the great monasteries on the Continent, European culture's first act in isolation was to eat itself.

This uncertain state produced mixed results, a combination of rejection and assimilation of the invading cultures. The process continues in Central Europe to the present day. Rodrigo Díaz de Vivar (EI Cid), a mercenary who lived in Spain during the 11th century, successfully hired himself out to both Christians and Muslims, yet helped advance the cause of the Reconquista to the extent that later generations reforged his image as a jingoistic patriot. 16 At the other extreme, the first Crusaders massacred the entire non-Christian population of Jerusalem, yet their descendants adopted so many Arab customs that their brethren in Europe accused them of betraying their faith. Islamic civilization influenced Spanish art, music, and language, but this did not stop the Christians from burning Muslim libraries and destroying as much of Moorish society as they could with every step of the Reconquista. Medieval

16 Peter Linehan, History and the Historians of Medieval Spain (Oxford: Clarendon Press, 1993), 204-7. 
Christian reaction to Islam was always ambiguous, and tinged with hostility.

\section{The First Crusade}

In the summer of 1099, the same year which saw the death of El Cid, an army of starving, maddened, fanatical men stormed the walls of Jerusalem and took the city with great slaughter. They called themselves "Crusaders" (the local inhabitants called them Franj, or "Franks"--and much worse), and they were the first of their kind. 17

Palestine had seen Holy War many times before. The ancient contests between the Hebrews and the polytheistic Canaanites and Philistines have been memorialized in the Bible. The Islamic jihad swept through the region in the 7th century, making both Christians and Jews strangers in their own birthplace. The Byzantines had launched many expeditions since then, to reclaim the area, with mixed success.

This was the first time, however, that the region would see European Christians in force. These followers of the Church of Rome, themselves descended from the barbarians who had pillaged the Roman Empire, came from countries only recently recovered from the centuries of disorder that followed the collapse of the Empire. The summer of 1099 was a reckoning, in more ways than one.

Four years before, the Patriarch of Constantinople had sent a letter to the Pope in Rome, asking him to supply mercenaries for the Byzantine frontier. The Pope and the Patriarch had not been on good terms since they had excommunicated each other in 1054. It was not the first time they had done it, 17 Amin Maalouf, The Crusades Through Arab Eves, xiv-xvi. 
but this breach proved to be permanent.

In 1095, however, reconciliation was still possible, and the Pope, Urban II, was interested in the Patriarch's proposal. Under Urban's predecessor, Gregory VII, the Roman Church had become embroiled in a dispute with the Holy Roman Emperor, Henry II. The Holy Roman Empire was what the remained of the German side of Charlemagne's empire. The dispute (called the Investiture Controversy) began over whether the Emperor or the Pope had final say over creating (investing) bishops and other clergy. 18

Henry would eventually lose the debate. In 1095, however, his opponent had been dead for nine years, and many German bishops supported Henry, who appeared to be winning. Urban felt a need to regain the Papacy's lost influence in Europe. He saw in the Patriarch's request a way to regain lost prestige and get rid of some of the more violent elements in European society.

Urban was astonished by the violence of the reaction to his speech. He would be the last Pope to underestimate the power of the Crusading ideal. In retrospect, one can see clearly the irresistible appeal of the ideal to the warrior class. Nor did Urban remain dumbfounded for long. He appears to have seen this crusade as an excellent opportunity to rid Europe of the violent elements which had ripped it apart.19

None of the leaders of the Crusade were kings. The Crusades were seen to be as much a risky venture for fabled loot as a holy war. The most prominent leaders, Godfrey de Bouilion, Baldwin de Boulogne, his brother, and Raymond de Saint-Gilles, were land-hungry nobles. Taking the land route by way of Asia Minor, the Crusaders set out for Constantinople. The non-noble

18 P.M. Holt, The Age of the Crusades: The Near East from the Eleventh Century to 1517 (London: Longman Group Limited, 1986), 16-19.

19 Ronald C. Finucane, Soldiers of the Faith: Crusaders and Moslems at War (New York: St. Martin's Press, 1983), 19-20. 
mob, led by Peter the Hermit, a preacher, began its journey by murdering all the Jews (a perennial ritual at the beginning of subsequent crusades) it could find in the towns along its route. Due to lack of supplies and a general lack of organization, this group quickly made itself unpopular by foraging and looting its way to Constantinople. It was waylaid by Seljuk Turks in Asia Minor. A massacre ensued, and most of the survivors were sold as slaves. 20

The armies of the nobility fared better. They arrived at Constantinople with their forces intact. The Emperor had been expecting a small band of mercenaries for his eastern front. So frightened was he by the rumors of Peter's mob that he bought off the knights and sent them south into Syria. It took them four bloody years to complete their journey, but at the end of it, they took Jerusalem. Baldwin gained Edessa and Armenia through an arranged marriage, and left the Crusade before it reached the city. Raymond and Godfrey continued on, taking Jerusalem after a prolonged siege in 1099. In the next twenty years, the Crusaders created the Counties of Edessa and Tripoli, the Principality of Antioch, and the Kingdom of Jerusalem.

At first, the Muslims were astonished to have lost Jerusalem, and thought that they would soon get it back. There was also a tendency to confuse the new invaders with the Byzantines, although this confusion soon gave way to anger. As they recovered from their shock, some Muslim writers began to call for a jihad (holy war) against the Franks. This movement became perilous to the Crusader states in the 1140's, shortly before the Second Crusade, when Muslim leaders began to use the concept as a way to gather and rouse their armies. 21

20 lbid., 20-1. For the attribution of crusader defeats to the killing of Jews, see Elizabeth Siberry, Criticism of Crusading, 101, 198.

21 Nikita Eliseeff, "The Reaction of the Syrian Muslims After the Foundation of the First Latin Kingdom of Jerusalem," in Crusaders and Muslims in Twelfth Century Syria, ed. Maya Shatzmiller (Leiden: E.J. Brill, 1993), 162-72. 
On the surface, this seems like a logical response to the coming of the Crusaders, especially when one considers some of the conquests that the Crusaders made well into the 1130's. The Arabs must have found such a strike by non-Muslims deep into Islamic territory very disturbing. When one looks deeper, however, the picture becomes much more complex.

Most Crusades historians now believe that the First Crusade prevailed because the Arab world was already disintegrating by the late 11th century. In the first three centuries after Muhammad's death, Islamic and Arab civilization were synonymous. The Arabs dominated an area that encompassed most of Asia Minor, North Africa, Spain, and Southern Europe. Aside from the Byzantines, they maintained the most highly developed civilization in Europe and western Asia at that time.

Beginning in the 11th century, however, a series of invasions from Central Asia began to wear down the borders of both the Byzantine and Islamic Empires. The Byzantines retained their unity, while watching their land and influence shrink. The Arabs, meanwhile, had already split into several competing nations--usually along the lines of Sunnism and Shi'ism.22 Their civilization fragmented under the assault of the barbarian invasions.

The first wave of invaders were called the Seljuk Turks. They swept into Asia Minor where they were bought off and converted--much as the Normans' Viking ancestors had been in 10th century France.23 As the Turks settled in, they increasingly pushed local Arabs out of positions of authority.24 Arab

22 Shiites and Sunnis divided during the war of succession following Muhammad's death. The Shi'ites favored a hereditary line of succession in Muhammad's nephew and son-in-law Ali (and his son, Husayn) as Caliph, spiritual head of the Islamic faith. The Sunni faction favored succession by election. Ali initially became Caliph. Sunni forces managed to murder both him and Husayn--but Husayn left descendants. The Sunnis won the initial battle, but, so far, have yet to win the war; Farhad Daftary, The Ismailis, 36-9.

23 Norman F. Cantor, The Civilization of the Middle Ages, 208.

24 Amin Maalouf, The Crusades Through Arab Eyes, 261-2. 
Muslim historians had difficulty explaining this humiliating conundrum. The Arabs were being pushed out of their own civilization by newly-converted Muslims. To make matters worse, while Spain, North Africa, Palestine, and Syria were predominantly Shi'ite, the Seljuks were Sunnis. Around 1090--9 years before the Crusaders took Jerusalem--the Holy Land went from Shi'ite to Sunni domination. Needless to say, this created considerable resentment among the population, which could not have entirely converted in so few years. This resentment led to protest movements such as the Assassins, who were an Isma'ili sect of Shi'ites. 25

Because of this intra-religious antipathy, and a loss of interest in the concept of jihad, and expansion, after the 9th century, the Muslims in Palestine were unable to organize effectively against the Christians.26 Until the late 12th century, individual Muslim leaders sniped at the borders of the Crusader lands, but made no serious inroads. The most important division was between fragmented Syria, dominated by a Sunni administration in Damascus, and the Egyptian Caliphate, which remained Shi'ite. Saladin's conquest and conversion of Egypt in 1171 made the disaster at Hattin and the fall of Jerusalem in 1187, possible. Egypt, which he once compared to "a whore", provided him with a large tax base and breadbasket on which to draw in his endless war against the Christians. 27 Ironically, Rome had used Egypt for the same purposes. The Egyptian civilization's longevity had given it one of the most stable economies in the Ancient and Medieval worlds.

Saladin's successes against the Franks arose from a set of circumstances which Muslim leaders could not duplicate again until the mid-13th century.

25 Ibid., 99-100.

26 Nikita Eliséeff, "The Reaction of the Syrian Muslims After the Foundation of the First Latin Kingdom of Jerusalem," in Crusaders and Muslims in Twelfth Century Syria, 162-3.

27 Andrew S. Ehrenkreutz, Saladin (Albany: State University of New York Press, 1972), 185-8. 
First, Nur-ad-Din, and his then general, Saladin, succeeded in conquering Egypt. Before them, the Caliphate had been too powerful to conquer. With the fall of Egypt, Muslim Palestine was unified for the first time since the First Crusade. This unity lasted only as long as Saladin's lifetime. After his death, his son and brother fought, His brother took Egypt, and his son, Syria. Muslim Palestine fell apart, and would only be reunited under Baibars, in the 1260's.

Baibars was a Mamluk. He was not Arab, but a Turk, and had little respect for either Arab or Frankish culture. Unlike Saladin, he was not known for his honesty. Although an able military leader, he was quite willing to use treachery (such as the taking of Safad) to reach his goals. He was also reputed to be excessively cruel.28

Although Baibars never lived to see the Franks out of Palestine, it was he who made it possible by driving the military orders out of central Palestine. His successors, Kalavun and al-Ashraf Khalil, were overshadowed by this figurative, and literal, giant in historians' eyes, but they were no kinder than he to the Christians. In 1291, during the final siege at Acre, Khalil was so anxious to take the Templar fortress, that he accidentally destroyed much of his army while collapsing the walls.

Crusading fervor did not end in 1291. The military orders continued to plot invasions. The would-be crusaders, however, were now at a serious disadvantage. They had no foothold left in Palestine, nor were they likely to acquire one after the Mamluk sultans destroyed previous Christian fortresses on the coast.29 14th and 15th century crusades either died in the planning stages, or ended in spectacular failure.

These centuries were also the age of plague, war, and schism. The Black 28 Amin Maalouf, The Crusades Through Arab Eyes, 248-9. 29 Ibid., 259. 
Death reoriented European focus in disastrous ways. Not only did new demographics dictate the consolidation of population inside European borders, but a new, more pessimistic attitude also rose up in the wake of 1349 . People became increasingly disillusioned about Christendom's military parity with Islam. Europe's attention turned inward.30

Finally, there were also two new, exterior threats to consider. The Mongols, despite being turned back at 'Ain Jalut, remained powerful and unpredictable. They continued to make conquests from eastern Europe to China, before breaking up into smaller khanates. Meanwhile, a new force, the Ottoman Turks, swept in from the east, swallowing up most of the Muslim realms, including the Mamluks, into a single empire. The Ottomans were dynamic and dangerous, and they continued to threaten Europe's borders until the 18th century. Their empire, itself, did not end until 1917, long after the Age of Crusade had ended. 31

\section{The Failure of the Palestinian Crusades}

The Crusaders' failure to hold their conquests in Palestine stemmed mostly from lack of manpower and a misunderstanding by European Christians of the severity of the situation in the Holy Land. The Frankish armies were usually outnumbered by the Muslims. Not infrequently, they allowed themselves to be goaded into battles which ended in costly defeats. Some historians have suggested that the Crusaders refused to assimilate into the local culture and

30 Elizabeth Siberry, Criticism of Crusading, 220.

31 Robert Irwin, "Islam and the Crusades, 1096-1699," in The Oxford Illustrated History of the Crusades, 250-9. 
tried to apply European political solutions to Palestinian problems.32 Whether or not the Crusaders did this (The Crusaders probably assimilated as far as they possibly could without completely losing support from Europe), it seems unlikely that it was the main reason for their failure. Racial and religious bigotry did not stop the Spanish from retaking the Iberian peninsula during this same time period. 33 Nor did it stop the Muslims from retaking Palestine from the Christians.

The common theme running through all of the Crusaders' complaints to Europe was the general lack of enthusiasm that the Franks back in Europe felt for the day-to-day defense of the Holy Land. This is not to say that the idea of the Holy Land was not important to the Franks, or that the image of Jerusalem was not cherished in the hearts of every European--Christian or Jew. It was. But the reality of Jerusalem never quite inspired the Christians the way the dream did. Once the crusaders reached Jerusalem, and took it, they became confused by the dichotomy between the heavenly Jerusalem and the earthly city. As a dream, the Holy Land was priceless. As a piece of coastline on the Mediterranean, it was rather less so. With the onset of the Age of Exploration, its market value fell to nothing.

\section{The Spanish Crusades}

Not everyone agrees that the Reconquista was part of the crusades. On the other hand, it had several elements in common with the Palestinian crusades.

32 A Symposium, "The Crusading Kingdom of Jerusalem--The First European Colonial Society?" in The Horns of Hattin, 364-6.

33 Philippe Contamine, War in the Middle Ages, trans. Michael Jones (Oxford: Basil Blackwell Ltd., 1984), 65-6. 
First, it was an attempt (successful, this time) to reclaim land which had once been Christian from the Muslims. Second, the conflict was drawn along strictly religious grounds. Third, mâny of those who participated in the crusades, also fought in Spain. Fourth, patterns of inter-religious assimilation in Spain paralleled those in Palestine--to a point.

The Palestinian Crusades and the Spanish Reconquista are separately treated in historiography and tradition. Yet, they were distinct fronts of the same war--the struggle for predominance between Christian and Muslim which began with the death of the Prophet Muhammad and continues today. Some historians believe, therefore, that these two series of events should be studied together, as examples of the same process. 34

It is impossible to truly understand the processes of tolerance and assimilation among the Franks in Palestine without also studying them in Spain. While some interactions between Muslims and Christians were the same on both fronts, others were quite different. This stemmed from Spain's proximity to Europe as one of its frontiers, and from how this proximity affected the two groups' ultimate fates in each region. Unlike the Crusades in Palestine, the European kings (especially those on the Iberian frontier) could not ignore the Moors (Spanish Muslims) whenever internal affairs became pressing. Participating in the Reconquista did not mean abandoning one's kingdom to go off on a foreign adventure for the glory of God. Often, it meant defending the southern borders of one's own kingdom.

Many European notions of Islam came from distorted views of the Moors. The Chansons de Geste, when they touched on real Islamic customs at all, situated their stories in the struggle of the Christians to regain southern France 34 Robert Burns cites Ramón Menéndez Pidal and Johannes Vincke as authorities in support of this view; Robert Ignatius Burns, Islam Under the Crusaders: Colonial Survival in the ThirteenthCentury Kingdom of Valencia (Princeton: Princeton University Press, 1973), xiii. 
and the Iberian peninsula.

This holds true for the Templars in Palestine and Spain, as well. The Templars on the lberian peninsula had different motivations, a different role in their society, and even a different fate from their brethren in the East and Europe. They were almost a separate group. There is even a surviving variant Rule called the Catalan Rule.

The Islamic possession of Spain lasted much longer than any of the Frankish realms in Palestine. The Franks ruled the coast of the Levant for 192 years. The Muslims of Spain dominated most of the Iberian peninsula from the 8 th until the 11 th century. After this, they began to lose ground to the Christian kingdoms. Yet they still held a third of southern Spain in the early 14th century, and were not completely conquered until 1492. In this year, the victorious Christian rulers of Castille and Aragon, Isabella and Ferdinand, began to expel all Muslims and Jews from Spain; the process was not complete until the early 17 th century. They also set the Inquisition on the conversos--Christians whose ancestors, willingly or not, had converted from Islam and Judaism. 35 Previous to this witch hunt, Muslims in the conquered territories had been allowed to practice their religion while experiencing second-class citizenship status.

For most of the nearly seven centuries in which Spain shared two cultures, the Muslim culture was much more highly developed than the Christian culture. The Muslims lived in an urban, international culture whereas the Christians lived in a mostly rural, parochial society. 36

Christians in France and Spain were not unaware of the disparities in cultural levels. This created apathy toward combating the invaders in

35 Jan Read, The Moors in Spain and Portugal, 205-11.

36 Thomas F. Glick, Islamic and Christian Spain in the Early Middle Ages, 6. 
Christians living under Muslim rule. Some communities in France and Italy also sought economic connections with the Muslims and used them as mercenaries.

By the period of the Crusades, however, some Christians (such as the author of the Gesta Francorum, an eyewitness account of the First Crusade) possessed enough self-confidence to speak admiringly of the Muslims' strength. Once Christians began to defeat Muslims in battle, they could afford to make themselves look more formidable by boasting about their beaten enemies' prowess. 37

The Muslims arrived at their greatest point of expansion in Spain in 732. In this year, Charles Martel encountered what was probably a raiding party of Muslims at Poitiers in southeastern France and defeated them. His grandson, Charlemagne, pushed the Muslim frontier back down into the Pyrenees in the late 8 th century. The Muslims may not have been very interested in advancing beyond Spain at the time. Martel's victory certainly did not deter them from continuing to raid the southern French and Italian coasts until the 11th century. Still, Martel appears to have discouraged them from invading France again long enough to give the Carolingians time to consolidate their power.

The Iberian peninsula remained almost completely Muslim until the 11th century. In the 10th century, the Christian county of Castille arose. The Castillians made sporadic forays against the Muslims, although these were tentative, at best. The Christians were unable to successfully challenge the Muslims until after 1035, when the counties of Castille and Aragon were elevated to the status of kingdoms. Portugal followed, in 1143.38

The military orders arrived on the stage fairly late in the historical drive of 37 Norman Daniel, Heroes and Saracens: An Interpretation of the Chansons de Geste (Edinburgh: Edinburgh University Press, 1984), 241-3.

38 Philippe Contamine, War in the Middle Ages, 56. 
the Reconquista. Thus, the power vacuum which existed in Palestine had already been filled by strong kingships by the time the Temple was formed. The Templars and the Hospitallers, therefore, were much more subservient to royal control than they were in Palestine, although they tried (not always successfully) to stay out of the conflicts which often occurred during this period between the Spanish kings.39 They tended to work within the power structure of the Spanish monarchs, rather than independently of it. 40 Consequently, their attitudes toward the Muslims in Spain tended to be more in line with general European attitudes than they were in Palestine. On the other hand, the Templars in Spain had generally lived near Muslims all of their lives. Unlike their confreres in Palestine, they did not have to acclimate overeager, xenophobic, new recruits to the realities of perpetual crusade. On occasion, Spanish Templars even allied militarily with Muslims, when convenient.41

The county of Toulouse, the Grand Duchy of Aquitaine, and the Kingdom of Navarre, in southern France, had also grown strong. By the 12th century, the Muslims of southern Spain no longer faced a weak, chaotic Europe, but instead, a group of powerful, competitive, and land-hungry realms who eyed Muslim land with both religious fervor and earthly cupidity. The Muslims, meanwhile, had grown used to the status quo, and were on the defensive. Being Shi'ites, they could not call for a jihad from the rest of Islam, which was becoming increasingly dominated by Sunnis. The Christians began to win significant battles.

By the mid-13th century, the Christians had taken back about two thirds of

39 Alan Forey, "The Military Orders and the Spanish Reconquest in the Twelfth and Thirteenth Centuries," in Military Orders and the Crusades, 214-21.

40 Alan Forey, The Military Orders, 50-2.

41 Alan Forey, "The Military Orders and the Spanish Reconquest in the Tweltth and Thirteenth Centuries," in Military Orders and the Crusades, 227. 
the Iberian peninsula. By 1300, the Christians began to address the possibility that this situation might be permanent. In retrospect, the eventual fall of Granada, in 1492, was as inevitable as the fall of Constantinople to the Turks in 1453. That the Christians were unable to advance into Saharan Africa, or that the Muslims were unable to regain any part of the Iberian peninsula, proved a fluke of history, rather than a clear-cut decision on either side. 42 Late 13th and early 14th century Spanish Christians suddenly faced a society in which they were the majority. Yet, the Spanish Christian realms still held sizable minorities of Jews and Muslims. In the period before the Black Death, the status of these minorities varied, depending on local conditions. If, as in Palestine, they lived in areas where there were not enough Christians to work the fields and maintain the marketplace, they were often reasonably tolerated. If, however, they lived in areas where there was not enough land or commerce to go around, they were treated harshly. Their treatment, overall, was dependent on their usefulness, and their lack of threat, to the dominant, Christian society. 43

The status of Jews and Muslims appears to have been similar to that of Jews and Christians under Spanish Muslim law. The two groups were legally distinct from Christians under the law code. Muslim advocates, for example, could not represent Christians. Nor could Muslims be witnesses in cases between Christians. Jews and Muslims were also, of course, more heavily taxed than Christians. This was a form of tribute for allowing them to remain in Christian Spain. 44

42 Robert Ignatius Burns, Islam Under the Crusaders, 65-6.

43 James M. Powell, ed., Muslims Under Latin Rule, 1110-1300 (Princeton: Princeton University Press, 1990), 6-7.

44 Joseph F. O'Callaghan, "The Mudejars of Castille and Portugal in the Twelfth and Thirteenth Centuries,"

in Muslims Under Latin Rule, 37-42. 
The strongest barrier was sexual. Sexual intercourse, let alone marriage, was forbidden outside the subject's religious group. Consensual, interreligious relationships (especially those between Christian women and minority men) were often punishable by death (usually by burning) for both participants. The mode of execution indicates a fear of the taint of heresy, which was growing in Europe during this period. Prostitutes were expected to maintain the sexual barrier, and could be punished severely for relations with non-Christians, unless they could prove that they had been tricked by their client. 45

This barrier was not limited to sexual intercourse. Muslim and Jewish women were forbidden to nurse Christian babies--and vice versa--and members of the three religions were forbidden to associate with each other in bathhouses. Muslims and Jews were also restricted in their choice of clothing, to distinguish them more easily from Christians. 46 Overall, the intention was to segregate the three religious groups as much as possible. While the Jews and Muslims disliked being subjected to the rule of the Christians, they appear to have approved as much of this sexual segregation as the Christians did.

\section{Cross-Cultural Relations in Palestine}

The evidence for social relations between cultures is sketchier in Palestine than in Spain. There do appear to have been, however, some similarities, as

45 David Nirenberg, Communities of Violence: Persecution of Minorities in the Middle Ages (Princeton: Princeton University Press, 1996), 143-8.

46 Joseph F. O'Callaghan, "The Mudejars of Castille and Portugal in the Twelfth and Thirteenth Centuries,"

in Muslims Under Latin Rule, 30-1. 
well as differences, between the two frontiers. The first problem, in Palestine, is that the area in question was, in fact, very small in relation to length of its frontier. The control that the Franks had over the region was always tenuous, at best.

In the regions which they did control, however, there seems to have been a general policy of subjugating the general population--regardless of religious affiliation--to an uneasy mix of serfdom and slavery. 47 This group included fellahin (peasants), and even the nomadic Bedouin. 48 This subjection seems to have applied mostly to the non-noble population. Noble Muslims living near the Crusader states, like Usamah Ibn Munqidh, retained their status in their travels through Frankish lands, and there are several references to landowning Turcopoles. Townspeople were also free, but subject to heavier taxation than Franks, who (in theory) could not be enslaved. In general, the status of non-Franks, including Oriental Christians, resembled that of dhimmis in Islamic states.

It is still debated whether the Franks constituted a minority, or a majority, in Frankish Palestine. Either way, the ratio of men to women among the Frankish population was probably quite high. 49 Inter-religious, and inter-class (therefore, inter-racial) marriage was discouraged by the Assises, the 13th century law of Palestine. Its legal status was left in doubt.50

Although Frankish men did engage in sexual relations frequently enough with Palestinian women to create a class of half-Syrian Franks, it is unclear

47 Joshua Prawer, Grusader Institutions (Oxford: Clarendon Press, 1980), 201-3.

48 Prawer mentions a Bedouin tribe that belonged to the Temple, although, whether the Templars actually owned the tribe, or had simply taken it under their protection in exchange for tribute, is unclear; Ibid, 214, 125.

49 Benjamin Z. Kedar, "The Subjected Muslims of the Frankish Levant," in Muslims Under Latin Rule, 148-9.

50 James A. Brundage, "Marriage Law in the Latin Kingdom of Jerusalem," in Outremer, 262-4. 
whether or not these unions were legitimate. Fulcher of Chartres, in the early 12th century, claimed that many Frankish men were marrying local women who had converted to Christianity from Islam. 51 Since conversion, either way, was never high (the Franks were often criticized for their lack of enthusiasm in converting the local population), Fulcher's assertion that all, or most, of these women were Christian converts is questionable. Whether the bulk of poulains were actually mixed-race Syrian/Latin Christians, and whether this group was demographically significant, or whether the image of the treacherous, halfcaste poulain was a popular enough motif in chronicles of the period to create the illusion of significance, is unclear. The poulains appear too often as stock traitors to make assumptions based on their frequency in chronicles definitive.

Overall, relations between Christians and Muslims in Palestine and Spain were dictated by political realities. This appears to have been true, regardless of whether the majority was Christian or Muslim. Jews, of course, were a perpetual minority, and might be abused by the other minority, as well.

While individuals might become friends or enemies based on personal circumstances, the factors which influenced legal codes and social customs were based more on a delicate balance between fear and utility. If the minority population was considered more useful than threatening, then laws and social customs tended to be lenient and flexible. If the minority population was considered to be a threat, and did not fill a necessary role in society, then it tended to be treated as a hostile element. At best, this element would be barely tolerated, and ringed round with laws and customs to keep it within safe, established boundaries. In times of stress, it could even be expelled from the community. Medieval ghettos did not exist solely in stone. 52 51 lbid.

52 James M. Powell, "The Papacy and the Muslim Frontier," in Muslims under Latin Rule, 185203. 


\section{CHAPTER FOUR: ARABIZATION}

\section{Introduction}

The question of whether or not the Templars were arabized raises several other important questions: What was the extent of the assimilation? What was its nature? What was the pattern of assimilation? How did this vary geographically and chronologically? How did it compare to the assimilation of the general Frankish and Spanish population? How did it vary within the Order? Were some groups within the Order more susceptible to assimilation than others? Who were the poulains? 1 What was their place in the Order, and

1 John Lord de Joinville, "Memoirs of Louis IX King of France," in Chronicles of the Crusades, 466. In this passage, Crusaders from Europe call De Joinville a poulain for siding with the local Franks. De Joinville, unperturbed, insults them back. De Joinville defines a poulain as a local peasant (the French equivalent would be vilein). The translator adds that the 24th chapter of the Life of Louis le Gros defines a poulain as "a child bom of an European mother by a Syrian father, 'Pullani dicuntur, qui de patre Syriano et matre Francigena generantur"' (Ibid., 466, no.1). Considering the great loss of status involved for the mother, however, it seems more likely that the average poulain was bom of a Syrian mother and a Frankish father, as indicated by Fulk de Chartres. Frankish women, as daughters of Eve, were strongly discouraged from going on crusade. Those who did were denounced as camp followers, at best, whores of Satan, at worst (Elizabeth Siberry, Criticism of Crusading, 44-6.). Frankish women, being a minority among local women would have sought out (or had arranged for them) more socially acceptable matches within their own race. The literal definition of poulain is "foal" or "colt" but "mustang" (U.S.), or "brumby" (Aus.) would give a better rendition of the intended meaning. Thus, the Crusaders compared the poulains to feral horses--brave and fierce, but also wild and untrainable. 
how did they differ from the Order's irregular troops, the Turcopoles? 2

Aside from actual cross-cultural relations, one must also consider perceptions--both European and Muslim--of Templar assimilation. The fantasy, as will soon be seen, was often vastly different from the reality. It was also more powerful. The Templars were suppressed because of their imagined sins, not their real ones--because of the perceived nature of their assimilation, not its true nature.

\section{Unholy Alliances}

During their tenure in Palestine, the Templars were periodically accused of making treaties with the Muslims that were contrary to Frankish interests, sabotaging Frankish-Muslim relations in order to profit from the prolonged conflict, preventing Muslim conversion to Christianity, and betraying the Frankish armies to the Muslims.

These charges centered around the Templars' alliances with the Muslims. In the making of such treaties, the Templars were scarcely unique. They often made agreements with the Muslims. So did everyone else. Their fault, as far as their Frankish enemies were concerned, lay in their self-perception as an independent, international organization which collectively held the status of a

2 The Turcopoles are generally described as troops recruited from the local populace who functioned as lightly-armed cavalry versed in the arts of local, Muslim warfare; Henri Curzon, trans., La Règle du Temple, Henri Curzon, ed., 75. According to Matthew Benett, they were skilled with the bow, in the Turkish manner; Matthew Bennett, "La Règle du Temple as a Military Manual, or How to Deliver a Cavalry Charge," in Studies in Medieval History Presented to

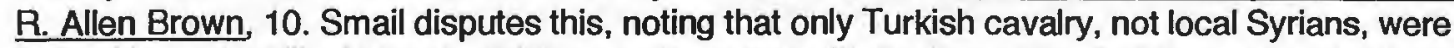
trained in such skills. Not only did Turcopoles serve with the Templars, but they were also found in the ranks of the Hospitallers and in the service of the local, Frankish nobility. They made excellent scouts; R.C. Smail, Crusading Warfare, 111-12, 179-80. 
king or emperor. 3 They therefore felt themselves perfectly justified in making treaties and exacting local taxes, although they do not appear to have created laws or held courts of justice. For the former, they relied upon the authority vested in them by the Pope. As has been pointed out in Chapter Two, the Templars were not unique among the military orders in this respect--either in attitude or in action. Both the Hospitallers and the Teutonic Knights had similar networks of alliances. The military orders had no reason to believe that they should defer to royal authority, since they answered only to the Pope.

The difficulty, especially in Palestine, was that European political power during the 12th and 13th centuries was still less than centralized. There was no coherent, long-term plan of action upon which all of the nobility and the military orders agreed. Each thus pursued separate, and often contradictory, policies. 4 The Templars appear to have run into difficulties of alliance whenever they clashed with a strong King. Amalric I of Jerusalem, Frederick II, the Holy Roman Emperor, and Louis IX of France all had conflicts with the Temple. All three of these monarchs believed strongly in an authoritarian government, with all power concentrated in their own hands. All three monarchs made treaties with the Muslims. It was only when the Templars made treaties of their own, or opposed treaties made by said kings, that they attracted charges of treachery.

Sometimes, the Templars were accused of assimilation because they opposed the king's breaking of a treaty. 5 Sometimes, the Templars received criticism for reacting badly when the king released an enemy, or hostile

3 Helen Nicholson, Templars, Hospitallers and Teutonic Knights, 43-8.

4 John L. La Monte, Feudal Monarchy in the Latin Kingdom of Jerusalem, 1100 to 1291 (Cambridge: The Mediaeval Academy of America, 1932), 83.

5 William, Archbishop of Tyre, A History of Deeds Done Beyond the Sea, vol 2, 350-1. 
vassal, of theirs from his obligations to the Templars. 6 The Templars were often left with the job of enforcing the unenforceable whenever a monarch's ambitions of political cohesion fell through. They were well aware of who would be picking up the pieces after a Crusade ended. Their bitterness about their shaky position shows through in these conflicts. ${ }^{7}$

The Templars often made treaties with the Muslims, and usually honored them--even in the face of strong criticism. 8 So remarkable was this stance, that even Muslim chroniclers noticed it. 9 Such integrity, however, does not appear to have sprung from any inherent racial or religious tolerance in the Templar personality. These alliances were always marriages of convenience, made on account of the Franks' weak military position, rather than any Templar love of Islamic civilization.

On the other hand, brothers of the Temple did gravitate toward the tolerant end of Christian-Muslim relations. In Spain, Templars sometimes fought alongside Muslims, rather than against them, when it suited the Order's longterm strategy. 10 The Trial occurred very soon after the solidification of the Spanish frontier. There is little evidence in Spanish Templar attitudes, therefore, of the overt xenophobia, exaggerated nationalism, and fear of

\footnotetext{
${ }^{6}$ As when Amalric made an alliance with an envoy of the Assassins, releasing them from their obligations to the Temple and Hospital. The Templar response to this attack on their independence was to ambush, and murder, the envoy; William of Tyre, A History of Deeds Done Beyond the Sea, vol. 2, 392-4.

7 Ibid, 192-4. For the Templars' reaction to Frederick's indefensible Jerusalem treaty; Malcolm Barber, The New Knighthood, 143-5.

8 The Templars opposed the Egyptian invasion planned by Amalric I, King of Jerusalem, because it violated treaties made by the Franks (and the Templars, themselves) with Egypt. Their opposition made them unpopular; Amalric was well-liked by the local Franks. The Hospital supported him, as well; John L. La Monte, Feudal Monarchy in the Latin Kingdom of Jerusalem. 25.

9 Ibn Alatsyr claimed that even Saladin respected a Templar's word; Sophie Menache, "The Templar Order: a failed ideal?" The Catholic Historical Review 79, no. 1 (January 1993), 4. 10 Alan Forey, "The Military Orders and the Spanish Reconquest in the Twelfth and Thirteenth Centuries," in Military Orders and the Crusades, 227.
} 
pollution that appeared in Spanish Christian responses to Spanish Muslims and Jews during the 14th century. Instead, we see the older attitude of flexible, almost cynical, accommodation that was best characterized by the real life El Cid. That powerful mix of fear, jealousy, ethnic pride, and feelings of old inferiority vs. new superiority which fueled the early colonization of South and Central America, and the Inquisition's reign of terror in 15th and 16th century Spain, postdates the suppression of the Templars. 11

While the military orders were usually unwilling to relinquish control of their slaves, even to facilitate conversion to Christianity, they also appear to have felt a feudal obligation to their Muslim vassals, serfs, and slaves. 12 in 1179 , the Temple made a successful complaint against some of the Hospital's Turcopoles in Beit-Jibrin, on behalf of a local Bedouin tribe that the Templars had taken under their protection. 13 In this case, the non-Christian Bedouin were included under the cloak of the Christian trifunctional society of bellatores, oratores, and laboratores (despite the fact that they were, technically, vagrants) by the Templars. That the Order exacted some sort of tribute in exchange for such legal representation goes without saying. What is remarkable, however, is that the Templars in Palestine were willing to extend the same privileges of military and judicial protection to nomadic nonChristians that Christian peasants could, theoretically, expect from their feudal

11 For the rise of Spanish Christian,ethnic self-identity (as separate from Iberian Jews and Muslims, and other Europeans); Thomas F. Glick, Islamic and Christian Spain in the Early Middle Ages , 202-5. For fears of miscegenation and racial purity; David Nirenberg, Communities of Violence, 13-16, 152.

12 Since no Latin Christian in Palestine could be held as a slave, the military orders were noticeably reluctant to allow any of their unfree subjects to convert. On the other hand, there appears to be no evidence that they supported forcible conversion, either. Like other Franks, they were willing to allow their subjects religious freedom--as long as they, themselves, retained political control; Benjamin Z. Kedar, "The Subjected Muslims of the Frankish Levant," in Muslims Under Latin Rule, 153-4, 160-3.

13 Joshua Prawer, Crusader Institutions, 125, 214. 
lords. 14

\section{Intimate Enemies}

The Templars were also not incapable of individual friendships with Muslims. During the Trial, an outside witness claimed that a late 13th century Templar Preceptor of Sidon, Matthew le Sarmage, had been blood-brothers with the Sultan of Egypt. 15

This was not an isolated anomaly. One of the most remarkable passages from the Crusades comes from the memoirs of a footloose, Arab Muslim prince named Usamah Ibn Munqidh. Curious, worldly, well-educated, and remarkably tolerant of other cultures, Usamah Ibn Munqidh led a life much like the English adventurer and translator of the Arabian Nights, Sir Richard Francis Burton, would eight centuries later. Usamah's father was the Emir of Shayzar, a town in northern Syria which dated back to pharaonic times. The father was not interested in the rigors of Emirship, so he ceded the position to his brother, Sultan. This caused problems for the adult Usamah when Sultan had sons of his own. Eventually, Usamah was forced into a lingering exile by his uncle's resentments. 16

Born in 1095, the year that the First Crusade ignited at the Council of Clermont, Usamah survived 93 years of war and politics. He was an illustrious poet, warrior, and diplomat in his day. His fame often saved him from the consequences of his more heterodox views. Not only was he a friend of the

14 Georges Duby, The Three Orders, 13.

15 Malcolm Barber, The Trial of the Templars, 186.

16 Usamah Ibn Munqidh, An Arab-Syrian Gentleman and Warrior, 10-11. 
Templars, for example, but he also picked up a certain affinity for Shi'ism during a sojourn in Egypt in the early 1150's. He had already led a life of high adventure when he became one of Saladin's advisors in his old age. He proved to be unreliably tolerant of the Sultan's enemies, however, and was soon put out to pasture. 17

Usamah's memoir is a remarkable document. It rambles from story to story, an effect of his advanced years--he dictated it at the age of 90 . In his prime, he was a noted poet. His memoir suffers from his not having written it down himself, and from the fact that the oldest extant version of it is a badly edited copy written decades after his death. 18 Still, it amazes the reader with its breadth, wit, and candor. Usamah was not afraid to discuss Saladin's savage temper toward those of his Muslim subjects who crossed him. 19 Nor, apparently, was he afraid to put himself between Saladin and such unfortunates. His equanimity--towards his uncle, his various misfortunes, and even the Frankish invaders whom he so often fought, is unique among both Muslim and Frankish sources of the period. Muslim writers were often fatalistic, but Usamah possessed this quality without the bitterness which so often accompanied it in his contemporaries.

Usamah also did not fear to discuss his acquaintances among the Franks. His significance as a Templar source comes from a remarkable passage (dated about 1140) in which he even referred to them as his friends. In this story, Usamah related his pet theory that the Franks, while violent and crude in their own environment, could be civilized by contact with Arab culture.

In this passage, Usamah discusses his routine during his visits to

\author{
17 lbid., 14. \\ 18 lbid., 17. \\ 19 Ibid., 186-90.
}


Jerusalem. First, he visits the al-Aqsa Mosque, which, at the time in question, is the headquarters of the Templars. To allow Usamah to conduct his prayers in peace, the Templars evacuate a small, unnamed mosque, which they have converted into a chapel, next to the al-Aqsa.20

One day, when Usamah is in the church, praying, a Frank, newly arrived to Palestine, attacks him; Usamah is praying in the wrong direction. Since he is facing Mecca for his prayers, he is facing east-northeast. The stranger insists that he face east (like a good Christian), presumably towards Eden. The Templars come in and remove the man, apologizing to Usamah. The man returns. The Templars eject him again. This happens several times. Finally, Usamah gives up and leaves.

There are three major translations of this passage (see Appendix A), although only one (Philip K. Hitti's translation) puts it in context with Usamah's general discussion of the Franks. Still, in all three passages Usamah refers to the Templars as his friends. All three passages make it clear that the Templars went out of their way to place a consecrated spot at Usamah's disposal for prayer. It is obvious, in this passage, that they were at pains to provide a place that not only Usamah considered sanctified, but that they, too, considered to be holy. What is also evident from this passage is that the Templars were embarrassed by the newcomer's intolerant behavior. Yet, they also seemed unwilling to expel the man completely.

It must be kept in mind that, during the Crusades period, most Muslims in Frankish territories were little better than slaves, and were mistrusted by both sides in the conflict. The hierarchy appears to have been: Latin Christians,

20 It was not uncommon for clerics to allow Muslims to pray in Christian shrines on spots which were also holy to Muslims. However, the Muslims generally had to pay well for the privilege; Benjamin Z. Kedar, "The Subjected Muslims of the Frankish Levant," in Muslims Under Latin Rule, 161-2. 
Oriental Christians, and then Muslims. Muslims were probably above Jews in status. Showing preference to Muslims over Christians, therefore, could be dangerous. 21

While the Templars clearly wanted to show hospitality to Usamah, they appeared to be walking a dangerous line by preventing a fellow Christian from harassing a Muslim at prayer. Usamah was, after all, performing a heretical ritual on Christian holy ground, and he was doing it on a semiregular basis. One must also wonder how the Christians who were hustled out of the church to make way for Usamah felt about the Templars' preference for his convenience over that of their co-religionists.

What the story does not tell us is how Usamah became such good friends with the Templars in the first place. Was he part of their spy network? Was he an ambassador for a Muslim ally? Had he personally saved the life of a Templar, or otherwise aided the Order in some way? The story gives no clue. What does seem clear, however, since he wrote his memoirs at a very advanced age, is that this strange friendship persisted until the end of Usamah's life in 1188.

The Templar story does not exist in isolation in Usamah's work. It is one of a string of anecdotes which Usamah used to support his theories about the civilizability of the Franks. In this collection of stories about the Franks, Usamah discusses his friendships with assimilated Franks, their medical practices and legal procedures (he found trial by ordeal especially barbaric), their peculiar religious beliefs, and one of his servants' near lynching at the instigation of an angry, Frankish war widow. This last incident was averted by an assimilated Frank whom an associate of Usamah's had befriended.22

21 Ibid, 158-160, 165.

22 Usamah Ibn Munqidh, An Arab-Syrian Gentleman and Warrior, 161-70. 
Passages such as a bathkeeper friend of Usamah's bizarre interlude with a Frankish knight in a public bathhouse are startling in their candor. One can only speculate what the pious Saladin and his courtiers thought of Usamah's friend Salim's agreement to shave, not only a Frank's pubic hair, but that of the Frank's "wife" (who was, more likely, a prostitute that the knight invited in as a joke on the bathkeeper). ${ }^{23}$ Usamah's perceptions of the Franks could be quite distorted, however. His assertions that Frankish sexual morality was loose and carefree, with the Frankish women exercising considerable sexual freedom, are not borne up at all by evidence from European sources. 24 It is more likely that Usamah was emphasizing a looseness in Frankish sexual mores in order to bolster his portrait of them as noble savages who possessed "neither jealousy nor zeal but...great courage."25

What is Usamah's point? In his passage on the Templars, is he trying to emphasize the barbarity of the new Frankish immigrant (who may, or may not, be a Templar recruit), or the civilized behavior of the Templars? Or is he trying to establish his cultural superiority over the Franks, by portraying himself as patient and tolerant in the face of their fanaticism?

Gabrieli does not comment on Usamah's passage, although his translation is the most intolerant in tone. Maalouf uses the excerpt to show the general ignorance and intolerance of the Franks toward the local, Muslim population. Only Hitti puts it in context, showing that Usamah was making a complicated, and surprisingly tolerant, comment on the civilizability (arabization, by Usamah's definition) of Palestine's new invaders. For Usamah, the Templars were among the few Franks who were becoming assimilated (therefore,

\section{Ibid., 165-6.}

24 Laura Brady, "Essential and Despised: Images of Women in the First and Second Crusades, 1095-1148" (MA Thesis, University of Windsor, 1992), 83-6.

25 Usamah Ibn Munqidh, An Arab-Syrian Gentleman and Warrior, 166. 
civilized by Arab standards) into the local culture. Hitti's translation of the passage is the longest of the three, and it retains the sense of humor and equanimity that Usamah maintained in the face of adversity.

Oddly enough, Usamah did not mention his friends, the Templars, in an incident in which he and they were on opposite sides. Usamah was in Egypt on a political mission in 1154. He was deeply embroiled in the plot by the Egyptian Vizier Abbas to assassinate the Caliph and replace him with Abbas's son, Nasir. Usamah apparently did not approve of the plot, but he did help the regicides escape when the Egyptian populace turned against them. Usamah did not mention the Templars in his account of the incident, even though they killed most of his party, captured his brother for ransom, and forced Usamah, himself, to flee for his life. Usamah only refers to his attackers as Franks. 26 Could he have been unaware that the Templars were responsible for the raid, or was he protecting them, for some reason? The answer is unknown, since the narrative breaks off at this point.

The significance of Usamah's memoir to Templar, and Crusades, history is that it shows that friendship was possible between free Muslims and the Frankish invaders. It is a glimpse at what might have come to pass, if the Crusaders had been able to establish a balance of power with their Muslim foes.

\section{Poulains and Turcopoles}

Templars also recruited among the poulains (native born Palestinian Franks). Poulains were regarded badly in Europe, probably because many of 26 Ibid., 44-54. 
them were half-caste bastards of Frankish men and Muslim Arab women. Latin Christians in Palestine often accused them of treachery, because they believed that the poulains had divided loyalties. 27 Initially, they could become knights. Regulations tightened against admitting bastards as knights, however, in the early 13 th century as the Church and society became increasingly disapproving of out-of-wedlock children.28 The differences between miles (knight) and pedes (footsoldier) also increased toward the end of the 12 th century as the knights' class rigidified into a caste under social and financial pressures. Innovations in armor design soon raised the price of knightly accouterments above the price range of any but the nobility. 29

Poulains were still allowed to serve as sergeants, or Turcopoles (lightly armed, Turkish-style cavalry who fought with the knights). Not all poulains were Turcopoles, particularly early on in the Order's history. Some of them were even knights, and not sergeants. 30 There is some confusion as to what, exactly, the difference was between a poulain brother and a Turcopole. Turcopoles seem to have been mercenaries who were only loosely attached to the Order's structure, whereas poulains could be full-fledged Templars.

27 Malcolm Barber, The New Knighthood, 167,191.

28 John Lord de Joinville, "Memoirs of Louis IX King of France," in Chronicles of the Crusades, 466.

29 R.C. Smail, Crusading Warfare, 106-7.

30 Malcolm Barber, The New Knighthood, 79; Desmond Seward, The Monks of War, 48. Neither author explains whether the Armenian prince, Malih, was a knight or sergeant. Considering his status as a noble Christian (albeit an Eastern heretic), however, he was probably a knight. Leon Cazelier, the Syrian Templar whom the Templar of Tyre blamed for betraying Safad to Baibars, was a sergeant. His second name, Cazelier, was probably a title. Caselier brothers guarded the Temple's farms (The Rule of the Templars, 53), and were important enough to be able to keep two horses, a squire, and the same food ration as the Grand Master (\#181). Leon Cazelier was referred to as "brother Leon" (Frère sergant [sergeant brother] Leon, in French, or Ifrir Liyun, in Arabic), by both the Templar of Tyre and Ibn al-Furat; The Templar of Tyre, "Chronique de Templier de Tyr," in Les Gestes des Chiprois, 180-1; Ibn al-Furat, Aiyubids, Mamluks, and Crusaders: Selections from the Tarikh al-Duwal wa'l-Muluk of Ibn al-Furat, vol. 2 (Cambridge: W. Heffer and Sons Ltd., 1971), 95-6. Knights and sergeant brothers, but not Turcopoles or "Saracen" servants, are also referred to as "brother" in the Rule. 
The distinction is important, because Turcopoles were not treated as well as the regular brothers, either knight or sergeant. In all of the regulations of the Rule which mention them, save one (\#610), Turcopoles came after the sergeant brothers in the text, just before the Saracen secretaries (who were probably Muslim slaves).

According to the Rule, Turcopoles ate apart from the Templar brethren (\#189). It was a punishment to be seated with the Turcopoles at meals (\#271). Overall, the Turcopoles appear to have been segregated from the Templar brothers. It is possible that the reason was one of religion. The true difference between a poulain and a Turcopole may have been that the poulains were Christians (albeit of an Eastern sect) and the Turcopoles were Muslim. Or, perhaps, the poulains were children of mixed-marriages who were raised in, or converted to, the Latin faith, whereas the Turcopoles were recruited from local Christian sects. One must question, however, whether local Christians, as dhimmis, would have been trusted to build up a military tradition and learn the necessary skills in the previously Muslim dominated society; the Turcopoles appeared in Frankish armies too early in the Crusades era for them to acquire their skills under Christian rule. 31

If the Turcopoles were Muslim, it would explain why they ranked only slightly above slaves (although the Franks did not treat native Christians much better than Muslims or Jews).32 The Temple had a large group of Muslim slaves who were skilled craftsmen, as well as secretaries and scribes. 33 If one

31 Benjamin Z. Kedar, "The Subjected Muslims of the Frankish Levant," in Muslims Under Latin Rule, 159-61.

32 Rules \#77, 99, 110, 113, 116, 120, 125, 254, 455. Slaves were as ubiquitous as horses, and often were spoils of war.

33 According to the Templar of Tyre, Baibars tried to ransom a group of Muslim slaves from the Templars and the Hospitallers. Both orders refused to give them up, citing their great value as skilled craftsmen; Benjamin Z. Kedar, "The Subjected Muslims of the Frankish Levant," in Muslims Under Latin Rule, 153. 
counts the unfree individuals under Templar jurisdiction, the Order may have possessed a sizable Muslim minority.

Nor was the Temple necessarily alone in being so islamized. Rule \#570 discusses the case of a brother who was a blacksmith (this would have made him a sergeant, or lower). This man, leaving the Templar fortress of Safad one night, went to stay on a nearby farm of the Teutonic Knights "which was full of Saracens." 34 Probably the writer meant that the man hid with the fellaheen (peasants) who worked the fields.

This man may well have been a Muslim peasant converted to Christianity. It would explain why he could turn to Muslim peasants for aid. It seems clear that they took him in, for they did not betray him to either the Templars or the Teutonic Knights; he returned to the Templars on his own. Perhaps, if he were a former peasant, he rediscovered his dislike for the life of a serf (which was what fellaheen essentially were, under both Muslim and Christian rule).

The man escaped expulsion from the Temple only because the Teutonic Order was in charge of the farm, and had its own baillis there. His error could thus be classified more as keeping bad company than treason. The meaning of this passage is unclear, particularly since Safad, itself, had a sizable complement of Syrian Christians, who could be considered to be Saracens in some quarters. 35 As with the Turcopoles, the difference appears to have been one of religion, rather than race or class.

With the increase in the prices of armor and horses in the 13th century, the ratio of sergeants to knights also rose. As time went on, sergeants became increasingly powerful in the Templar ranks. The Temple's massive banking institution was run by sergeants or clerks. Sergeants were in charge of

34 The Rule of the Templars, J.M. Upton-Ward, trans., 148.

35 Malcolm Barber, The New Knighthood, 167. 
equipment acquisition and transfer, and even had a hand in electing a new Master of the Temple. In the late 13th century, at least, even some the captains in the Templar fleet were sergeants. 36 The sergeants resembled modern day, military enlisted, personnel--except that they had more options for advancement, and appear to have exercised considerably more power within their organization than their modern counterparts. In fact, through the sergeants, poulains--a group despised by both sides, yet heavily assimilated into local Arab culture--could have exercised considerable political control in Palestine during the late 12 th to early 14 th centuries. 37

\section{The Charges}

The five main charges made against the Templars at their Trial were: the denial of Christ, the desecration of the cross through spitting, treading, or urinating on a crucifix, obscene kisses made on the navel, buttocks, or genitals, sodomy, and the worship of either a head or an idol in the shape of a cat. 38

These charges can all be found in anti-Muslim propaganda predating the Trial. Guillaume de Nogaret attacked the Templars by portraying them as crypto-Muslims. All of these charges reflected European fears and fantasies, rather than any real Templar arabization or contemporary Muslim practices

36 Ibid., 240-1. See also Francisco de Moncada, The Catalan Chronicle of Francisco de Moncada 11-14. Roger de Flor, a pirate captain, had been taken in as a boy by the Templars and made a sergeant brother. Accused of simony and piracy, he escaped to become a pirate in fact. He sold his services to the Byzantines until his murder in 1305.

37 Desmond Seward, The Monks of War, 53. Seward theorizes that most of the army which perished at Hattin was made up of poulains.

38 Malcolm Barber, The Trial of the Templars, 45. 
and beliefs. Some previous criticism of the Templars had been connected to their relations with the Muslims (i.e. making treasonous alliances with Muslim princes), but this did not appear directly in their Trial. The charges which were brought against them in 1307 stemmed from their perceived arabization, not their actual arabization.

The first charge, the denial of Christ, reflected a common European fear of apostasy and betrayal. The Templars, themselves, addressed this concern in their Rule. Abandoning the Order to join the Muslims (\#230) was one of the seven offenses meriting expulsion. This was not a fear to be taken lightly: several incidents of Templars joining the enemy (either through fear, bitterness or common cause), have been recorded in the Rule and contemporary chronicles. 39

Another, related, offense, leaving a fortified dwelling of the Order by any but the main entrance (\#228), meant essentially the same thing as rule \#230. In this case, however, the accusation appears to have been one of active treason against the Order by betraying one's post, as opposed to simple desertion. If a brother repented and returned, and could prove that he meant no active harm against the Order, then he might only lose his habit (\#570). On the other hand, even threatening to desert to the Muslims could lose a brother his habit, as well (\#240).

The Templars were not the only Christians to go over to the Muslims. In fact, probably a smaller percentage of Templars than secular knights actually

39 The most notorious such traitor was Leon Cazelier, an Arabic speaking, Syrian sergeant brother, who betrayed the Castle of Safad to Baibars "pour paour de mort [for fear of death]" in 1266. Incidents of treason involving others, however, such as Toros, Leon's Hospitaller partner in betrayal (Ibn al-Furat, Aiyubids, Mamluks, and Crusaders, vol. 2, 95-6.), the renegade Armenian prince Malih ( Malcolm Barber, The New Knighthood, 226-7), and several brothers mentioned in the Rule have been recorded (\#569-70, 573, 603); The Templar of Tyre, "Chronique du Templier de Tyr," in Les Gestes des Chiprois, 180-1. Ibn-al Furat claimed that Baibars treated Leon well after the castle's fall, and that Leon later converted to Islam. 
deserted to the enemy; the punishment was harsher for a Templar than for a secular knight. Also, Templars were much more disciplined than secular knights.

Templars who deserted to the Muslims after capture in battle were believed to have converted out of fear of death, rather than true denial of their Faith. The charges against the Templars, however, claimed that their denial was genuine, and came out of a sort of heretical madness. 40

The desecration of the cross comes directly from accusations made against Muslims whenever they seized important churches, or relics like the Splinter of the True Cross. Tales of Muslims dragging crosses through the streets of a conquered city were common. These became more prolific and virulent toward the end of the Crusades in Palestine.41 Ironically, even the Templars resorted to such propaganda, as when Terricus, Commander of the Temple, stirred up indignation in the West with a letter in 1188 claiming that Saladin had a large cross in Jerusalem torn down and beaten with clubs. 42 Stories of Muslims spitting and urinating on crosses, and forcing captured Christians to do so, as well, were also common. 43

The charge of obscene kissing, and the charge of sodomy are essentially the same accusation. 44 This is not only because both charges involved irregular sexual practices between members of the same gender, but because both were connected to the sin of heresy.

The obscene (and ritualistic) kissing, is related to stories which began to circulate about heretics in the 11th century. In these stories, a group of 40 Malcolm Barber, The Trial of the Templars, 45.

41 Norman Daniel, Islam and the West, 110-1.

42 Malcolm Barber, The New Knighthood, 114.

43 Malcolm Barber, The Trial of the Templars, 185.

44 Anne Gilmour-Bryson, "Sodomy and the Knights Templar," Journal of the History of Sexuality 7, no. 2 (1996): 151. 
heretics held services where they adored a demon--usually in the shape of a black cat. Sometimes, they worshipped an idol in the shape of a cat, instead, or a sorcerous head. Either way; all of these rituals ended in sexual orgies. 45 Although these stories became popular in northern Europe only in the 11th century, they were, in fact, far older. The Romans had made similar accusations against the early Christians, and other Eastern mystery cults. 46

The definition of sodomy was much broader than it is now. It included not only homosexual relations, but also anal sex, or irregular sex of any kind, between a man and a woman. Irregular sex, in medieval terms, meant anything but the missionary position. In stories where both sexes were present at a heretical orgy, women usually presented themselves, buttocksfirst, to the men for anal sex. 47 This definition narrowed by the late 13th century, however. Most of the participants at the Templar Trial (prisoners and inquisitors) appear to have been aware that the word was being used to describe anal sex between men.

Sodomy was intimately connected with sorcery and heresy, and its prosecution usually involved the Inquisition. 48 Both Cathars and Muslims were believed, by early 14th century Europeans, to engage in it frequently. 49 It was regarded by most Europeans, including the Templars, as an abominable $\sin$. In the 13th century, sodomy replaced theft in the list of offenses that

45 Malcolm Barber, The Trial of the Templars, 178-82.

46 Norman Cohn, Europe's Inner Demons, 1-10.

47 Malcolm Barber, The Trial of the Templars, 180-1.

48 Anne Gilmour-Bryson, "Sodomy and the Knights Templar," Joumal of the History of Sexuality, 163.

49 Ibid., 191. 
merited expulsion from the Order (\#418). 50

Very few brothers actually admitted to this charge during the Trial. Although many claimed to have been given permission, at their reception into the Order, to relieve sexual tension through homosexual acts, they insisted that they had not done so. Some describing their violent responses to being propositioned, or ordered to engaged in relations with another brother. 51 Others claimed to have heard stories of fellow brothers (usually conveniently dead) who had committed sodomy.52 These stories often described nonconsensual, and predatory, sex forced on lesser brothers by their superiors. 53 Some claimed to have been raped, and/or beaten into submitting to the act. 54 Here, in the charge of sodomy, is where the connection between the Templars, the Cathars, and the Muslims was made. Rumors of homosexual practices in Islamic culture filtered north from Spain during the 9th and 10th centuries. 55 The actual cause is not known, but by the 11th century, sodomy

50 "The fourth is if a brother is tainted with the filthy, stinking sin of sodomy [fust entaichés de l'ort puant pechié de sodomie], which is so filthy and so stinking and so repugnant that it should not be named"; The Rule of the Templars, J.M. Upton-Ward, trans., 112; La Règle du Temple, Henri Curzon, ed., 229.

51 Anne Gilmour-Bryson, "Sodomy and the Knights Templar," 173, 175.

52 lbid., 156-7.

53 The confessing brother often claimed to have victimized by a superior officer in the Order (even De Molay was implicated in this way), thus kicking responsibility for the act upstairs; Ibid., 166.

54 In one coniession from a Templar senving-brother at Poitiers, Gilmour-Bryson and Barber diverge on translation. The witness, Etienne de Troyes (Gilmour-Bryson calls him 'Stephen'), claimed that he was propositioned by a brother named Paul de Valleceli. Etienne refused him. Here Gilmour-Bryson and Barber disagree. Gilmour-Bryson states that Etienne expressed his refusal by breaking Paul's jaw, whereas Barber states that it was Paul who beat Etienne, forcing him to submit in the end. Either way, Etienne, being a lowly serving brother, was not in a strong position to refuse such advances, if they were made to him by a superior. Peter Safet, a witness at the Pontifical Commission in 1311 and also a serving brother, testified that he had been sexually molested by a Spanish Templar who was closely associated with the Grand Master. Peter claimed he had not resisted for fear of the Grand Master's wrath; Ibid., 175-7; Malcolm Barber, The Trial of the Templars, 59-60, 100-1.

55 John Boswell, Christianity, Social Tolerance, and Homosexuality: Gay People in Western Europe from the Beginning of the Christian Era to the Fourteenth Century (Chicago: The University of Chicago Press, 1980),194-200. 
was being connected both with heretics and Islam.

The faith of the Albigensian Cathars had originated in Byzantine Eastern Europe.56 Toulouse had also been subject to Muslim depredations between the eighth and eleventh centuries. The Arab invasion of Europe through Spain and Sicily had been an even greater shock to Nogaret's ancestors than the Albigensian Crusade; the Muslims dominated the region for several centuries.

Little wonder that southern Europeans saw the Muslims as embodiments of Satan's army. Still, it was an army with which Europeans on the southern coasts had come to an accommodation. Pirate raids gave way to mutually beneficial trade. 57 Yet, as the military threat of Islam receded, the fear of the internal threat of Eastern heresy grew.

Perhaps heretics were connected, as internal enemies, with Muslims, who were external enemies. This period did coincide with growing hostility toward Jews (the traditional infidel within Christendom's walls), as well. It is also possible that orthodox Christians confused the extreme celibacy of the more Manichean groups (especially the Cathars) with homosexuality. To admit that heretics (who were generally fundamentalists) might be more devout Christians than orthodox believers, was, naturally, unthinkable. 58

No actual historical association between the Templars and the Cathars exists. The goals and attitudes of the two groups could not have been more dissimilar: the Templars were crusaders; the Cathars were pacifists who opposed the wars against the Muslims. The Templars ate meat regularly; the Cathars were vegetarians. The Templars discouraged asceticism (\#15)

56 Walter L. Wakefield, Heresy, Crusade and Inquisition in Southern France, 1100-1250, 27-31. 57 Zoé Oldenbourg, Massacre at Montségur: A History of the Albigensian Crusade, trans. Peter Green (New York: Minerva Press, 1968), 24-5.

58 John Boswell, Christianity, Social Tolerance, and Homosexuality, 284-5. 
whereas the Cathars practiced it vigorously. The two groups are similar only in that they were both suppressed as heretical organizations by the Church and the Kingdom of France.

Not only did contemporary European thought connect sodomy with the Muslims, but the Templar Rule did, as well. In rule \#573, the single example given for the sin of sodomy, three brothers were expelled from the Order for engaging in homosexual acts. Their sin apparently came to the attention of the rest of the Order because not all of their partners were consenting; an investigation was made only after some of the other brothers in the chamber with the offenders complained directly to the Grand Master. The three were caught, and imprisoned in Château Pèlerin ('Atlit), but one escaped. He deserted to the Muslims. 59 For the anonymous author of the Rule, it seems to have been perfectly natural for a sodomist fleeing the Order's justice to seek asylum with the Muslims; the Muslims, as practicers of sodomy themselves, would be sympathetic to his plight. If the Templars genuinely believed that the Muslims actively practiced sodomy, then they must have been terrified of being captured and imprisoned by them.60 This would explain the Order's

59 "At Château Pèlerin there were brothers who practiced wicked sin and caressed each other in the chambers at night [usoient de mauvais pechié et manjoient de nuit en chambres]; so that those who knew of the deed and others who had suffered greatly by it [si que cil qui estoient près dou fait, et autres qui trop l'avoient soufert] told this thing to the Master and to a group of worthy men of the house. And the Master took the advice, that this thing should not come to chapter, because the deed was so offensive, but that the brothers should come to Acre; and when they had arrived, the Master put a worthy man [prodome] in the chamber, and others in his company in the chamber where they were, and made them remove their habits and put them in heavy irons. And one of the brothers, who was named Brother Lucas, escaped by night and went to the Saracens [echapa de nuit et ala as sarrazins]. And the other two were sent to Château Pèlerin; and the one thought to escape, so he died [murdered, perhaps?], and the other one remained in prison for a long time;" The Rule of the Templars, J.M. Upton-Ward, ed., 148; La Règle du Temple, Henri Curzon, ed., 297-8 (Rule \#573).

60 Medieval Europeans believed that Muslims were especially fond of young boys, since western Christians had developed a brisk trade in young male slaves to certain Muslim dynasties. It was a small leap of logic from sexual abuse of helpless children and adolescents to abuse of prisoners, who were also vulnerable to such advances; Malcolm Barber, The Trial of the Templars, 191. 
violent revulsion to sodomy; a sodomist was an internal enemy, a cryptoMuslim. This was a perceived arabization, by Templars, of other Templars, and not a positive one.

Another interesting aspect of this passage is the fact that clearly more than three brothers were involved. This was not a friendship which went too far, a love affair, or simply a sexual liaison between two men; that there were three condemned in the incident, not two, precludes such relationships.

It is also clear that the three brothers were preying upon other brothers in the chamber, and that still others were aware of this fact. Yet, the brothers who were victimized were not subjected to punishment themselves. This directly contradicts the notion (firmly rooted in ancient, medieval, and modern attitudes toward homosexuals) that the one being sodomized is the one who is the true homosexual. 61

What the confessions during the Trial, and the story in Rule \#573, indicate is that most, if not all, of the Templars were incapable of seeing sodomy as a consensual act. In fact, they saw it as a crime of violence against another Templar, an assault which only an enemy of the Order (a crypto-Muslim) would commit. In this context, it was a sin of power and aggression, rather than of deviant sexual behavior. This would explain why some Templars were more willing to confess to being victims of sexual assault or harassment, than to being active participants--despite cultural prejudices against passive partners in homosexual relationships.

In the past, Templar historians have attempted to solve the question of whether the Templars engaged in the acts in question. This is a perfectly reasonable tack, since the charges were so lurid, and so successful in tainting

61 Because he took the woman's role in sexual intercourse; Anne Gilmour-Bryson, "Sodomy and the Knights Templar," Journal of the History of Sexuality, 164-5. 
the posthumous reputation of the Order. Such investigation, however, is hampered by the fact that no criticisms relating to sexual improprieties of any kind (with either men or women) which predate the Trial have been found against the Templars. This is a most interesting anomaly, since non-military, monastic orders were occasionally accused of sodomy. Even the Hospitallers came under some criticism for relations with prostitutes. The Templars, however, never did. Some chroniclers even insisted that the Templars were too busy making money to engage in sexual acts. 62

Anne Gilmour-Bryson has noted that the few brothers who did confess to engaging in actual sodomy expressed no shame over the acts which they described in such lurid detail, whereas brothers who confessed to denying Christ or desecrating the Cross expressed considerable shame and remorse.63 Yet, the answers which the prisoners gave relating to sodomy, particularly those where the brother received permission to commit the act but refrained from doing so, sound coached. Not only is there no shame, but no depth, as well. Those who did confess to committing sodomy described acts which seem unrealistic, at best, considering the constant supervision under which a Templar brother lived. One wonders where the "worthy men" [prodeshomes] were who were overseeing the behavior of these brothers when such behavior was occurring. It seems most likely that the prisoners in question were simply parroting what their inquisitors had placed into their mouths, even more so than with the other charges. Perhaps more intense torture was used with the men who confessed to sodomy than with the other brothers, or perhaps those who made this confession were more susceptible

62 Helen, Nicholson, "Saints or Sinners? The Knights Templar in Medieval Europe," History Today 44 (1994): 33.

63 Anne Gilmour-Bryson, "Sodomy and the Knights Templar," Journal of the History of Sexuality, 182-3. 
to such methods. This conclusion is reinforced by the fact that no Templars confessed spontaneously to sodomy. Only areas where torture was employed produced such confessions. 64

There is no question that homosexual behavior, probably including sodomy, did occur within the Order. By the 13th century, it was seen as a serious enough problem by the authors of the Rule to merit inclusion in the conditions for expulsion. Only one example is given in the Rule, however, and the behavior described did not extend beyond illicit touching.

Furthermore, there is no external evidence of sodomy from any sources before the Trial. Finally, the vast majority of the Templars denied actually engaging in sodomy. Those who did confess to it did so only under torture, and tended to be members of prisoner groups that were carefully selected and coached in the desired admissions before giving testimony. 65

Overall, the evidence indicates that sodomy within the Temple was not common. Whether it was less common than in non-military, monastic orders is not known, but the lack of pre-Trial external criticism of the Order in this area indicates that it was. One must always bear in mind, when examining the charges brought against the Templars, that the accusations were written months before the general arrest in France, did not change substantively as evidence was gathered over the course of the Trial, closely resembled the charges which Nogaret brought posthumously against Pope Boniface VIII, and were never proven to Pope Clement V's satisfaction, despite the extensive use of torture.66 In the end, Clement decided to suppress, rather than dissolve, the Order because the evidence was inconclusive, despite his

64 Ibid., 171.

65 Ibid., 175.

66 John Boswell, Christianity, Social Tolerance, and Homosexuality, 297. 
fear of Philip, and the French monarchy's success in permanently tainting the Order's reputation.

The most bizarre charge made against the Templars was that they worshipped an idol in the shape of a head. They were also accused of worshiping a cat, "[which] sometimes appeared to them in their assembly."67 The more popular form was the head. Sorcerous heads, often conceived through necrophilia, were a common motif in medieval folklore.68 The charges claimed that these heads were either idols (with one face, or three) or relics, that the Templars believed the heads possessed generative and moneymaking properties, and that they also believed the heads/idols were representations of God and the Saviour.69

Some Templars claimed to have adored the mummified head of Hugh de Payens, their founder.70 Others said that the head, or idol, had a long, white beard and was called "Baphomet" (a corruption of "Muhammad"). In this way, the Templars were accused of being crypto-Muslims who worshipped Muhammad. It did not matter that Muslims were, and are, strict monotheists who despised all visual representations of God, and considered Christians to be the idolaters. Nor did it matter that they revered, but did not worship, Muhammad as a human prophet, and did not consider him to be divine. Nor did it matter that such information was readily available in European contacts with Muslims. Although some educated Christians knew better, most European Christians believed that the Muslims worshipped idols, and adored Muhammad as a deity. 71

67 Malcoim Barber, The Trial of the Templars, 248.

68 Ibid., 185-8.

69 lbid., 249.

70 lbid., 100.

71 Peter Partner, The Knights Templar and their Myth, 77-8. 
Images of Muslim idolatry were disseminated primarily through the Chansons. 72 These images resembled the Ba'als that the Canaanites worshipped in the Bible.73 Their actual shape is not described, but some Christian writers saw them as representations of Venus/Aphrodite. This appears to have been a confusion of the abjuration that Muslims made of one of the Ka'abah's original roles in the worship of the Arab Aphrodite.74

Guillaume de Nogaret's men searched the Templar treasury for relics, statuary and images of the type residing in any notable clerical treasury of the age for evidence of idolatry. They found a single reliquary, shaped like a woman's head, which contained pieces of the skull. The label on the skull read "capud LVIII."75 The prosecutors could find nothing heretical about the head; it was a perfectly orthodox relic.

For nearly two centuries, the Templars had operated in a land saturated with relics both real and fake. Yet, the prosecutors found only a single relic. Did some of the Templars, somehow warned about Philip ahead of time, spirit such relics away, or had the brothers of the Temple ceased to believe in the power of relics by the beginning of the 14th century? It is true that relics had lost the central role in society which they had possessed in the 9th to 11th centuries, but they were still important, and lucrative, focal points for saints' cults. 76

Helen Nicholson has shown that the Templars did, in fact, keep and venerate relics during their sojourn in the Holy Land--especially those connected to cults involving female saints. They even went so far as to

72 Norman Daniel, Islam and the West, 309-312.

73 Norman Daniel, Heroes and Saracens, 149-152.

74 Norman Daniel, Islam and the West, 310.

75 Malcolm Barber, The Trial of the Templars, 163.

76 Patrick J. Geary, Furta Sacra, 25-7. 
support the canonization of local anchoresses. Apparently, this veneration of holy women stemmed from their devotion to the Virgin Mary. 77 In light of this, the presence of the reliquary in the shape of a female head seems perfectly ordinary. Its uniqueness, however, does not. Where did all of the other relics go? And, if the Templars no longer kept relics by the beginning of the 14th century, why not?

That the charges also gave the idols of the Templars the shape of a cat (either black or red, or brindled--all colors of sin and evil) makes sense. 78 In the early 13th century, Caesarius of Heisterbach conflated the cat with "the devil [who] on account of his rapacity is compared to a cat and a lion, who are very much alike in appearance and in nature, especially in their lying in wait for the souls of simple persons."79 This was a very early version of the cat as devil. Caesarius appears to have been referring to the cat's hunting behavior, rather than its later role as a Devil's familiar, in his analogy.

Both the lion and the cat were perceived as symbols of the mysterious Orient, due to their popularity in ancient Egypt. The cat was worshipped in the ancient Near East as Bast or Bastet, a benevolent mother, and sun, goddess of Egypt. The lioness, a wildcat, was worshipped as Sekhmet, a destructive sun goddess. Herodotus mentioned the Egyptian veneration of cats in an account of his visit to that country. Medieval Europeans were certainly aware of this account; Plutarch mentioned one of Herodotus' stories in his Moralia. 80

Muslims continued the Egyptian tradition of keeping cats as pets. Ancient, pagan Arabs had worshipped the cat in the form of a golden idol. The Prophet

77 Helen Nicholson, Templars, Hospitallers and Teutonic Knights, 116-9.

78 Norman Cohn, Europe's Inner Demons, 88.

79 Malcolm Barber, The Trial of the Templars, 185.

80 Katharine M. Rogers, The Cat and the Human Imagination: Feline Images from Bast to

Garfield (Ann Arbor: University of Michigan Press, 1998), 11-12. 
Muhammad owned at least one cat, who was named Muezza.81 According to legend, Muezza once fell asleep upon the sleeve of the reclining Prophet. Rather than disturb her, Muhammad cut away the sleeve of his robe--which was his favorite--when he stood up to leave. 82 This, and other stories about the Prophet's love of felines, influenced later Muslims to show a great affection for this animal which was not evident in Europeans until the 18th century.

Even the 13th century scourge of the Templars, the Mamluk Sultan Baibars, followed a tradition of his time in bequeathing a garden in Cairo as a sanctuary for that city's feral cat population. His symbol was a large wildcat, probably the lion which the Templars so feared and hated. 83

Prior to the Trial, European attitudes toward cats were neutral. Early medieval references focused on their value as mousers and rat-catchers. 84 Robert Delort suggests that they were rare in Europe until the Crusades, when the Franks brought back so many to combat the influx of Black rats (Rattus rattus) that they became common. 85

Other sources, however, indicate that cats were already common in Europe by the 12 th century. Throughout the Middle Ages, as in Roman times, Europeans often conflated cats with common dogs and other species of rat catchers, such as weasels. 86 Shortly after the first appearance of the Black Death, it became a common civic ritual in Europe to slaughter the dogs and

81 Robert Delort, Les animaux ont une histoire [The History of Animals] (Paris: Éditions du Seuil, 1984), 424.

82 Christabel Aberconway, ed., A Dictionary of Cat Lovers, XV Century B.C.--XX Century A.D. (London: Michael Joseph, 1950), 244-5.

83 Jaromir Malek, The Cat in Ancient Egypt (Philadelphia: University of Pennsylvania Press, 1993), 137.

84 Katharine M. Rogers, The Cat and the Human Imagination, 19.

85 Robert Delort, Les animaux ont une histoire [The History of Animals], 425.

86 Katharine M. Rogers, The Cat and the Human Imagination, 14-18. 
cats in a town whenever an outbreak of the Plague occurred. At the time, medical experts believed that these animals, not rats, were carriers of the disease. Ironically, this practice probably exacerbated the problem by eliminating the town's rat-catchers--since rats, and their fleas, were the actual plague vector. 87

The medieval image of cats was utilitarian and neutral enough that they were suggested as pets appropriate to female ascetics in a Rule for anchoresses (Ancrene Wisse or Ancrene Rilwe) in the 13th century and were not enumerated by the Templars, according to a mid-13th century version of their Rule (\#258). This regulation suggests that cats and dogs (but not hunting hounds) were ubiquitous in Templar convents. 88 Brothers in the Order may even have kept them as pets.

Rule \#258 forbids a brother to give away any animal of the Temple--save a dog or a cat. 89 It seems unlikely that the brothers ate these animals; the Order would have wanted to keep a head count of all food animals. Since cats and dogs were exempt from the regulation, they would have been impossible to enumerate. Thus, brothers probably did not eat them. Vermin would not be enumerated, either, but they are not mentioned. Brothers could not have used the dogs for hunting, since hunting (especially using dogs or hawks) was

87 Mark S.R. Jenner, "The Great Dog Massacre," in Fear in Early Modern Society, eds. William G. Naphy and Penny Roberts (Manchester: Manchester University Press, 1998), 47-50.

88 This would explain the references in the charges to cats appearing mysteriously in the midst of a closed assembly. Those brothers charged with security for chapter meetings would not have bothered to ferret out all of the sleeping cats and dogs in their corners, any more than they would have rousted the rats and mice. It would not be unusual for a dog or cat, awakened by torchlight and the sound of voices to come out and investigate the meeting, particularly if it could expect to be greeted with affection--and food.

89 "The twenty-sixth thing is, if a brother from the sheepfold or stable gives away any animal except a dog or cat [donast beste, fors de chien ou de chat], without the permission of his commander, the habit is at the discretion of the brothers, whether to take it from him or let him keep it;" The Rule of the Templars, J.M. Upton-Ward, trans., 77; La Règle du Temple, Henri Curzon, ed., 161. 
forbidden by Rule \#55 (except for the killing of lions) and active foraging was forbidden by Rule \#151. It seems possible, then, that Templar brothers kept these animals as companions.

Hermits in the 6th and 9th centuries also mentioned cats as their sole companions. 90 Perhaps the main attraction of cats for anchorites was their reputation for independence. Since cats could not be owned, and had no great value, they could be companions without violating a hermit's vows-either of poverty or of solitude.

The 13th century monastic Rule for anchoresses forbade nuns from keeping any animals besides cats. The author of the Rule felt that keeping useful farm animals made a nun more like Martha, the overly practical sister of Lazarus, than Mary Magdalene, his more spiritual sister, and Jesus' favorite female disciple. 91

As for Templars, their vow of poverty was absolute. Their lives were subject to continuous discipline. Though raised in a class that showed more affection toward animals than serfs, they could own neither. They could not hunt with hawks or dogs, and dared not show a preference even for their horses lest they lose them.92 For such men, keeping cats, and ordinary dogs, as companions may have been an important outlet for their love of animals.

Considering Delort's theory that the Crusaders imported cats, it is significant that Europeans saw both the cat and the lion as symbols of pride. 93

90 For the 6th century, see; Robert Delort, Les animaux ont une histoire The History of Animalsl, 424. For the 9th century; Katharine M. Rogers, The Cat and the Human Imagination, 26; Frank O'Connor, trans., Kings, Lords, and Commons: an Anthology from the Irish (New York: Alfred A. Knopf, 1959),14-15. This practice appears to have been most prevalent among the Celtic (Irish and Welsh) hermits, who practiced extreme asceticism.

91 Ancrene Wisse, Guide for Anchoresses, trans. Hugh White (London: Penguin Books, 1993), 192-3.

92 The Rule of the Templars, J.M. Upton-Ward, trans., Rule \#'s 55, 154, 251, 315, and 606.

93 Katharine M. Rogers, The Cat and the Human Imagination, 24. 
Pride, along with simony, was the vice most often attributed to the Templars. 94 The Templars, themselves, saw the lion as a symbol of chaos, and of the Muslim threat to Christianity. 95 One of the few remaining self-portraits of the Templars, a vivid, late 13th century fresco from San Bevignate in Italy, shows four pious-looking Templars--bearded and wearing white, hooded cloaks-defending a fortress against a huge lion. In the background, palm trees and a sand dune clearly mark the setting as the Holy Land.96

Muslims, for their part, perceived the lion as a symbol of courage. 97 They hunted lions and leopards to prove their prowess. 98 Islamic heros were identified so much with lions in legend, that Arabic epics of the Crusades era often featured highly ritualized accounts of lion hunts.99 Small wonder that the Templars described their enemy with this metaphor.

One significant image of cats, which appeared in the charges, did emerge during the 11th century, although it did not affect general attitudes toward real cats until the mid 15th century. The Abbot Guibert de Nogent told the story of a group of heretics who worshipped the Devil, in the shape of a great black cat, with obscene kisses and secret orgies. 100 Walter Map revived the tale against 94 Helen Nicholson, "Saints or Sinners? The Knights Templar in Medieval Europe," History Today, 32-3.

95 "Be sober, be vigilant; because your adversary the devil, as a roaring lion, walketh about, seeking whom he may devour;" I Peter 5:8; "This above-mentioned prohibition of hunting is by no means intended to include the lion, for he comes encircling and searching for what he can devour, his hands against every man and every man's hand against him (\#56)." This simile could as easily describe one of the Muslim brigands that the Templars were created to fight, as the Devil; The Rule of the Templars, J.M. Upton-Ward, trans., 33.

96 Malcolm Barber, The New Knighthood, 205-7.

97 Peter Heath, The Thirsty Sword: Sirat 'Antar and the Arabic Popular Epic (Salt Lake City: University of Utah Press, 1996), 273n.11.

98 Usamah Ibn Munqidh, An Arab-Syrian Gentleman and Warrior in the Period of the Crusades, 135-42.

99 Peter Heath, The Thirsty Sword, 109-18.

100 Guibert of Nogent, A Monk's Confession: The Memoirs of Guibert of Nogent, trans. Paul J. Archambault (University Park: The Pennsylvania State University Press, 1996), 195-7. Norman Cohn, Europe's Inner Demons, 49. 
another French heretical group in the 12th century. 101 Alain de Lille, in the late 12th century, wrote in Against the Heretics of His Times that the name Cathar came from the vulgar Latin for "cat", cattus. This story (which was untrue) derived from tales circulated by the Romans against the Eastern mystery cults, and later, the early Christians. 102 Thus, the connection between heresy, demon cats, and the East (and the Muslims, who were already considered idolaters) was made, and given the caché of antiquity.

These tales established a ready association between cats and heretics that remained latent during the 13th century, but made ready material for Guillaume de Nogaret in 1307. Ironically, the image of the Devil as a giant cat had no apparent effect on the actual perception and treatment of cats in real life until after the Trial.

After the suppression of the Templars, the really evil stereotypes began. First, cats (and dogs) were killed as plague carriers. Later, in the 16th century, iconography began to portray cats as servants of the Devil, or images of chaos. ${ }^{103}$ The legend of felines as familiars to ugly, old witches echoes, in sinister fashion, the benign ideal of the anchoress with her quiet companion. Herodotus's stories (such as how one can tell the time of night, or the phase of the moon, from the brightness of a cat's eyes) were recounted, magnified, and given a sinister twist. Other stories from Greek and Roman authors (who were not noted for their kindness to cats) added to this aura of evil, feline mystery.

This is not to say that the Trial, alone, created the witch craze of the 16th and 17 th centuries, only that it helped fix certain stereotypes (which were originally used to attack heretics by casting them as crypto-Muslims or

101 Walter Map, De Nugis Curialium[Courtier's Trifles], 118-21.

102 Norman Cohn, Europe's Inner Demons, 21-2.

103 Katharine M. Rogers, The Cat and the Human Imagination, 45-58. 
pagans) of witches in the public consciousness. The Trial must be seen in the context of Philip's reign, and the reign of his four sons. In 1303, Philip-through De Nogaret--mortally attacked Pope Boniface VIII and posthumously accused him of witchcraft. During the same year, the great Italian magnates were stripped of their wealth and driven out in one of Philip's uniquely piratical taxation drives.104 This expulsion was not permanent, but Italian influence on royal fiscal policy decreased considerably until he expelled them again in 1311.105 In 1305, Bishop Guichard was accused of using witchcraft and poison to kill the Queen, Jeanne de Navarre. He was eventually cleared, years later, but never regained his former health and reputation.106 In 1306, the Jews were pillaged and many were expelled from the Kingdom of France. The rest were expelled in 1313.107 In the autumn of 1307, the Templars were arrested and tortured, en masse.

In 1310, the Beguines and Beghards, a mixed tertiary sect of urban

104 Medieval Italian merchants were often considered to be more heavily islamized even than the military orders. The Italian moneylenders who traded in other countries were commoniy referred to as "lombards," and it was not a complimentary term. The term referred to the Italians' presumed origins in transalpine Gaul (northern Italy) where a barbarian tribe, called the "Lombards" had established themselves during the breakup of the Roman Empire in 5th and 6th centuries; Raymond de Roover, Money, Banking and Credit in Medieval Bruges, 100-3. The region was also home to two of the most notorious Italian city states during the Crusades era: the Venetians and the Genoese. These city-states had a justifiable reputation for treating with the Muslims extensively--even it it meant betraying Christian interests. The Templars had close ties with the colonies of the Genoese, the Pisans, and the Venetians in Palestine. A 13th century map of Acre shows the Genoese and Pisan city quarters situated right under each of the two land-facing walls of the Temple quarter (two sides of the Temple's quarter faced the sea), making useful buffers against the quarters of the Hospitallers. The Venetian quarter buffered the Templars and Pisans against the Teutonic Knights; Malcolm Barber, The New Knighthood, 242; David Jacoby, "Les communes italiennes et les ordres militaires à Acre: aspects juridiques, territoriaux et militaires [The Italian Communes and the Military Orders at Acre: Judicial, Territorial and Military Aspects] (1104-1187, 1191-1291)," in Etat et colonization au Moyen Age et à la Renaissance [State and Colonisation in the Middle Ages and the

Renaissancel, ed. Michel Balard (Lyon: la manufacture, 1989), 193-214.

105 Joseph R. Strayer, "Italian Bankers and Philip the Fair," in Economy, Society and Government in Medieval Italy, 113-21.

106 Norman Cohn, Europe's Inner Demons, 185-92.

107 Léon Poliakov, Jewish Bankers and the Holy See: From the Thirteenth to the Seventeenth Century, trans. Miriam Kochan (London: Routledge and Kegan Paul, 1977), 42-3. 
mendicants, were suppressed. One of their leaders, Marguerite Porete, was burned in that year. Officially, her sin had been the writing of a book which the French bishops deemed heretical.108 More likely, it was her gender and her independence from ecclesiastical authority which condemned her. Mixed communities of nuns and monks had once been common, before the 10th century, but had long since been regarded with suspicion. As the orthodox Church had turned its back on them, women had become increasingly involved with heretical movements. 109 By the early 14th century, religious women who strayed outside the straitjacket of silent, self-destructive ascetic risked fatal condemnation.

In 1321, groups of shepherds (Les Pastoureux) declared a holy war against several out-groups in France. The lower classes, motivated by mass hysteria and encouraged by the Crown, accused Jews, Muslims, and lepers of engaging in a plot to poison the wells of France. They killed several thousand from these groups, and raided the castles of several nobles, before they were dispersed. They arose again in 1324. The Church and the Crown believed the rumors of conspiracy, but feared the chaos which had resulted in 1321. The movement was repressed again, this time for good. 110

Suppressing groups which were already perceived as arabized was an easy way to have a crusade without actually going to the Holy Land. Philip, who revered his grandfather, Saint Louis, never made serious plans to go to Palestine. It was so much easier, so much safer, and so much more profitable to stay home and crusade against out-groups.

108 Barbara Tuchman, A Distant Mirror, 334-5.

109 Malcolm Lambert, Medieval Heresy: Popular Movements from Bogomil to Hus (New York: Holmes and Meier Publishers, 1977), 174-81.

110 Malcolm Barber, "Lepers, Jews and Moslems: The Plot to Overthrow Christendom in 1321," History 66, no. 216 (February 1981), 1-17. 
Once the djinn was let from the bottle, however, the French kings and their lawyers could not call it back. At first, they did not want to, but soon, the violence of the mob became an unmanageable tool. Rousing hatred against anyone who seemed different came with a long-term price which more than canceled out Philip's short-term gains, and ultimately destabilized civic order in France just at the time when the monarchy needed to rely on it the most. After the suppression of the Templars, generalized mob violence increased. Mobs targeted out-groups like the Jews, but now anyone could be accused of being in league with the marginal peoples of society and thus be marginalized themselves. Naturally, the terror of the Black Death only exacerbated the situation. 111

As a powerful military order, the Templars had been unassailable. Recast as crypto-Muslims and sorcerers, they became easy prey. Also useful was the message which their suppression delivered to other independent groups, like the Hospitallers, the Franciscans (whose radical arm, the Fraticelli, was condemned as heretical by Pope John XXIII in 1321), and the Italian merchants. These groups became much more cautious about wielding their power, and their public images, afterward.112 Ironically, it was this erroneous reputation which would carry the Templars' living memory into the 20th century, even as those groups who survived have faded, and been forgotten.

The audience of De Nogaret--Philip IV--must also be considered. Philip saw himself as the successor to his grandfather, Saint Louis, and as "that most Christian and most illustrious King of France" who Ramon Lull, the famous, early 14th century, Christian missionary to the Muslims, hoped would

111 Jeffrey Richards, Sex, Dissidence and Damnation: Minority Groups in the Middle Ages (New York: Routledge, 1994), 13-21, 163.

112 Desmond Seward, The Monks of War, 219-22. 
regain the Holy Land in a great crusade. ${ }^{113}$ As Louis' heir, Philip fantasized of leading this great crusade against the Muslims, but the dream did not become reality. 114 Although he never saw the Holy Land, nor met any Muslims, and though he appears to have had no intention of ever actually going on Crusade, Philip perceived Islam as Christianity's one great enemy. It was a shrewd maneuver, therefore, for De Nogaret to cast the Templars as secretly pro-Muslim. With all the rumors that the Templars had betrayed the Holy Land to the Muslims, and the Templars' refusal to unite with the Hospitallers into one Order under Philip's banner, Philip was primed to believe such insinuations. 115 Nogaret's artful fantasies converted these insinuations into facts in Philip's mind.

Historians have argued for centuries about Philip's motives concerning the Trial of the Templars, how much he manipulated, or was manipulated by, his counselors, and how much of the accusations made against the Order did he really believe. Philip certainly profited from the Order's downfall, although not as much as he would have liked. He also appears to have believed that the Templars were guilty of the crimes attributed to them. Whatever the case, he appears to have had a remarkable capacity for self-delusion when it suited his purposes. It seems probable that, in the end, the ends always justified the means for Philip the Fair, whenever the ends brought him what he most wanted.

113 J.N. Hillgarth, Ramon Lull and Lullism in Fourteenth Century France, 92; Elizabeth R. Brown, "The Prince is Father of the King: The Character and Childhood of Philip the Fair of France," Mediaeval Studies 49 (1987), 310, 333-4.

114 Aziz S. Atiya, Crusade, Commerce and Culture, 96-8.

115 Pierre Dubois, The Recovery of the Holy Land, trans. Walther I. Brandt (New York: Columbia University Press, 1956), 28-30. 


\section{Conclusion}

As many questions as may be answered with current evidence, many more remain obscure. What were the ties of friendship, respect, and even some religious tolerance that bound the early Templars to Muslim nobles like Usamah Ibn Munqidh? Why was the Temple willing to seek redress for a raid made by Christians on a poor group of nomadic Bedouin? Were the Bedouin, who wandered freely between Muslim and Christian territory, spies for the Temple? How did the military orders recruit local Syrians for the Turcopole regiments? Who were the poulains and what was their true place in Crusader society? What was the real status of Muslim slaves in the Temple? What was the nature and organization of the rumored Templar spy network in Palestine? Who were Guillaume de Beaujeu's contacts, how were they cultivated, and why were they willing to risk their lives to warn him, over and over again, of Mamluk intrigues?116

These are, at the moment, unanswerable questions. Due to the destruction of Templar documents at various points in the past seven centuries, statistical evidence for the Order in Palestine is impossible to find. Even anecdotal evidence is relatively rare.117 Also, assimilation into the local Muslim culture, however inevitable over two centuries, was not something that any of the military orders would have wished to advertise. The Templars' mission was to conquer (or convert) the enemies of Christianity, not reconcile with them.

Nor were Muslim sources likely to admit any tolerance of the new invaders. It would have been tantamount to a betrayal of their faith. Unfortunately, it is difficult to determine the level of assimilation by the Templars precisely because of the uncompromising nature of the Crusades ideal. Fueled by

116 Malcolm Barber, The New Knighthood, 175-6.

117 Ibid., 394-8. 
lingering millennial fever, the Crusades fostered a manichaean world-view where the only thing that both sides could agree upon was that one of them was evil, and would have to be destroyed in order to bring Heaven on Earth. To become tolerant of the enemy was to let Satan into one's soul, to risk eternal damnation. Most medieval people, Christian or Muslim, were unwilling to take such a risk. In some ways, that attitude has not changed as the second Millennium fades, and apocalyptic fervor grips society once more. 


\section{CHAPTER FIVE: TEMPLAR SURVIVALS}

\section{The Myth}

One of the great mysteries of the late Middle Ages is why the myth of the Templars survived their suppression. Today, the number of people who claim the title of "Templar" exceeds the entire mass of historical brethren of the Temple--both knights and sergeants. Why?

An aspect of this mystery is the insistent belief of neo-Templars in the idea that the original Order was heavily arabized--so much so that it became a mystical (or demonic) group versed in arcane secrets of the Orient. 1 It is easy to laugh at this movement, for many of its members are all too risible in their illogic. The thought process of many neo-Templars is: if it is an interesting idea, and it fits my obsession, then it must be true. In other words, they base their views on faith, not research.

Many serious historians dismiss such groups out of hand. The movement, however, is a historical fact. Merely ridiculing it does explain it. For some reason, there are people living in the late 20th century who are members of groups which, for the past four centuries, have felt the need for a living Order

1 Peter Partner, The Murdered Magicians, 91-6. Partner blames a 14th century German philosopher, Henry Cornelius Agrippa of Nettersheim, for making the connection between Templars and witchcraft. As was seen in Chapter Four, however, Philip's ministers had already made this link by employing charges of idolatry and sodomy, and by the close, chronological link between the Templar Trial and the persecution of the Beguines and the Beghards. 
of the Poor Knights of the Temple of Solomon. Since the real Order was suppressed seven centuries ago, people have invented a host of successors to take its place. The Order of the Knights Templar is now a hydra of populous, and conflicting, organizations. Many of these groups are benign. Others, like the Ku Klux Klan, the German Nazis, and certain skinhead groups, are profoundly malignant. Both sides profess to follow the ideals of the same defunct Order. If terrorists like Osamah bin Laden can refer to Israeli Jews as "Crusaders" then perhaps the Crusades--and the Templars--are not quite as dead as historians generally believe.

\section{The 'Killer App'}

A recent concept in computer technology is the idea of the "killer app," short for "killer application."2 This is an invention, or new concept, which so changes the existing paradigm of a culture that it transforms said culture beyond recall. 3 Some historical examples of killer apps include: the stirrup, the horse collar, the long bow, postal service, the railroad, the telephone, the automobile, the airplane, the personal computer, television, and the Internet.

Most of the above ideas, at first, look like simple inventions. If one looks closer, however, one sees that these are really entire concepts of how to do something in a completely different manner than it had ever been done before. Cavalry existed before the stirrup. Plow farming existed before the horse collar. Archers were used extensively before the long bow was invented. People received letters before postal services were set up, traveled 2 Larry Downes and Chunka Mui, Unleashing the Killer App: Digital Strategies for Market Dominance (Boston: Harvard Business School Press, 1998), 3-4.

3 Ibid., 16-18. 
around the world before the first rail was laid or the first automobile or plane built, communicated long distance before the telephone, did their taxes in less than a month and wrote millions of books before the appearance of the personal computer, and survived quite happily without either of those two great time wasters: television and the Internet. Yet no one, either the supporters or the detractors of these ideas, can dispute that each one of these inventions transformed the cultures they were created in so completely that it eventually became impossible to remember how one coped without them before they existed.

The Templars were also a killer app. They were the first heavy cavalry unit (using the stirrup) to emphasize military discipline. They were the first military group in Indo-European societies to provide soldiers with a way to combine their military skills with a religious life on a permanent basis. They were one of the first truly independent, and international, organizations in medieval society. They were one of the first groups to engage the Muslims, however imperfectly, on an equal footing in war and politics. 4

The measure of the Templars' success can be found in how certain groups within the Church reformed themselves in answer to the new challenge. The Hospitallers, an established monastic group, added a military wing that soon overshadowed the Hospital's more traditional activities. 5 Other monastic and clerical groups harshly criticized the new Order as they saw it drawing away their revenues. 6 Unfortunately, one of the more distinctive, and negative, aspects of a killer app is its darwinian effect upon older organizations as it rips through a culture, leaving chaos in its wake. Because a killer app's effect is

4 Karen Ann Wickens, "Military Ethics for Christians, Knights and Soldiers" (Th.D thesis, Harvard University, 1994), 73-6.

5Malcolm Barber, The New Knighthood, 38-9.

6 lbid., 56-63. 
universal within a culture, it is impossible for an organization to ignore it, or that organization will wither in the long run.7

Despite the abrupt suppression of the historical Templars in 1311, their ideal has clearly not yet run its course. In fact, neo-Templarism has grown stronger as the Millennium approaches. This makes some sense; the original Templars themselves sprang from a classic millennial concept--the Crusade. That particular concept, like the concept of jihad, which may have inspired it, is still very, very popular with all the wrong people. 8

So, what is it about the medieval Templars that makes people want to be Templars seven centuries after a strong French king and a weak Pope engineered their suppression? When neo-Templars discuss what prompted their interest in the original Templars, they invariably bring up the mystical aspects of the Order. The irony here is that, at this point in a discussion with a neo-Templar, any serious historian of the medieval Order will then ask, "What 'mystical aspects'?" There are none. The Poor Knights of the Order of the Temple of Solomon were a singularly hard-headed group of men--from beginning to end. "Non nobis, domine, sed nomini tuo da gloriam [Not to us, oh Lord, but to you give the glory]," and "Beauseant," make wonderful battle cries, but they were not designed to bring one any closer to God in a mystical sense. Ironically, what may have preserved the memory of the Templars, as if in amber, may well have been the same thing that destroyed them--the charges made against them at their Trial.

7 Despite their emphasis on killer apps as technological innovations, Downes and Mui use mythological, rather than scientific, metaphors to describe them: "Killer apps are the Holy Grail of technology investors...but like the Hindu God Shiva, they are both regenerative and destructive;" Larry Downes and Chunka Mui, Unleashing the Killer App, 4-5.

8 Some historians have suggested that the Templar concept of a Christian military religious order may have sprung from the Muslim concept of the ribat. Ribats were religious centers in Islamic Spain, set up for the pursuit of jihad combined with a spiritual life. Unfortunately, no. evidence has yet been found that the founders of the Temple were even aware of the existence of the ribats; Malcolm Barber, The New Knighthood, 40-1. 
As stated in Chapter Four, the essential purpose of the charges written by Guillaume de Nogaret was to smear the Templars as crypto-Muslims and, therefore, enemies of Christianity. Many still believe these charges, and parrot them without a trace of irony. 9 The world has changed a great deal since 1307, however, and not all Christians believe in either an infallible Pope or semi-divine Byzantine Emperor. Enemies of the medieval Church became martyrs for free thinking as early as the 18th century Enlightenment. 10 The Force is finally with the heretics, the witches, and the pagans.

Today, the taint of Eastern heresy actually attracts interest in the Order, rather than repels it. The Templars have gone from being crypto-Muslim heretics to mystical, Oriental sorcerers. As before, they are a liminal group, but now, instead of being an army invading from within or without, they are a bridge between cultures.

9 An episode from the television series, Highlander, and a segment from Discovery Channel's TerraX, now defunct, are chilling examples of the durability of Nogaret's propaganda. In these programs, the lurid images of the charges are recast and magnified for the entertainment of a modern audience; "Avenging Angel," Highlander: The Series, written by Fabrice Zolkowski, produced by Barry Rosen and Gary Goodman, directed by Paolo Barzman, 50 min. Gaumont Télévision, 1993; "The Knights Templar," TerraX, written by Rob Goldberg, edited by Joe Camperiati, 20 min., ZDF/ARTE for Discovery Channel, 1995.

10 Voltaire, especially, had many sharp things to say about medieval Christianity's fantasies about heresy and sorcery, and its insistence upon punishing imaginary enemies. His essay on Atheism criticizes, in detail, the charges of sexual morality leveled against the Templars and other groups prosecuted for heresy, although it does not mention the Templars by name; Voltaire, Philosophical Dictionary [Dictionnaire philosophiquel, trans. Theodore Besterman (London: Penguin Books, 1972), 49-58 [Atheism], 115-41 [Christianity], 252-6 [Inquisition]. Voltaire believed that the Templars were innocent of the charges made against them; Peter Partner, The Knights Templar and their Myth, 127-8. Gibbon was even less kind to the Church, which he believed caused the downfall of the Roman Empire, than Voltaire. He, himself, had no love for the military orders because he saw them as groups of religious fanatics who, like other monks, misused their power. He did, however, commend their courage, in an off-hand way: "They neglected to live, but they were prepared to die,0 in the service of Christ;" Edward Gibbon, The History of the Decline and Fall of the Roman Empire, vol. 6 (Philadelphia: John D. Morris \& Company, 1912), 81-2. 


\section{Gnostics, Templars, and Druids, oh my.}

As disorganized as neo-Templars and other New Age groups may seem, their belief system is, in fact, precise. Those who participate in these types of revivals target specific groups for their veneration. The most popular historical groups connected to the neo-Templar movement currently are: The Templars, the Gnostics, the Cathars, and the Druids. 11 Similar movements attempt to revive Mediterranean goddess cults and witches' covens. 12

The groups mentioned above are important for several reasons. First, they were (or were perceived by their contemporaries as being) very influential in their time period. These were groups with international influence, who existed at several levels of their society. The Templars' fame in their time was undoubted. Since that time, they have come to embody both the virtues and the faults of all the military orders--regardless of whether these qualities were unique to the Templars, the Hospitallers, the Teutonic Knights, or one of the

11 As early as 1781, a group of "modern Druids" adopted Masonic practices, and claimed that they had revived the ancient rituals of the Druids. Instead of referring to their gatherings as "lodges," like mainstream Freemasons, they called their meetings "groves," Charles William Heckethorn, Secret Societies of All Ages and Countries, vol. 2 (New York: University Press, 1965), 295; It was Hammer-Purgstall, in Mystery of Baphomet Revealed, who first put forth the triangular connection between the Gnostics, Cathars and Templars when he claimed that the Templars were secretly manichaean heretics; Peter Partner, The Knights Templar and their Myth, 156-60. The most frightening thing about this theory is that it almost makes sense. Due to the general lack of education in the Order, the Templars were, not infrequently, heretical in their personal beliefs and practices. As for their tendency toward manichaeanism, there are few medieval concepts more crypto-manichaean than the Crusade. The military contest between the good Crusaders and the evil Saracens, to decide whose god would prevail, was a trial by combat writ on a grand scale. It was not a concept, however, in which the Cathars had any faith; Malcolm Barber, The Trial of the Templars, 203-4.

12 Modern day goddess worshipers and witches (Wiccans) both seek to resurrect a mythical past where women had a dominant, or at least, equal, place in society with men. In this past, women were honored and respected, as were elements of today's society which are associated with the feminine. Goddess societies were supposedly more peaceful, and more environmentally-minded, than later, male dominated societies. For goddess worshipers, these societies were uprooted by the rise of monotheism in the Ancient World. For Wiccans, such groups survived among women until they were wiped out in the witchcrazes of the 15th-17th centuries; Lucy Goodison and Christine Morris, "Exploring Female Divinity: From Modern Myths to Ancient Evidence," in Ancient Goddesses: The Myths and the Evidence (London: British Museum Press, 1998), 6-21. 
secular orders.

Second, all of these groups were suppressed by the Christian Church. They are thus seen as underdogs, martyrs, and rebels by people who feel misunderstood by modern society. By joining revivals of such groups, these individuals acquire a sense of belonging. There are also shadow movements who see these revivals as conspiracies of evil, and dedicate themselves to stopping whatever resurrection that frightens them. Fundamentalists, both religious and political, seem to find such groups especially frightening. Thus, we see claims, in the present day, that neo-Templar groups like the Freemasons promote conspiracies in our governments. 13

Third, these suppressed groups were once in the mainstream and were espoused by a large percentage of the population within their sphere of influence during their time. They were then able to persist long enough, even under persecution, to disseminate many of their ideas into orthodox thought. It is no coincidence that these groups strike a chord with some modern day people. Today's culture has conditioned people to respond to certain ideas which have survived from these suppressed groups. Medieval tales which saw the Templars (accurately or not, is unknown) as the friends of illicit lovers were common in the 13th century. Stories of King Arthur and his knights, which were created by Crusades groupies like Chrétien de Troyes and Wolfram von Eschenbach in the 12th and 13th centuries remain popular. 14 Such tales have given the Templars a posthumous reputation for chivalry 13 The anonymous "Publishers," who reprinted an anti-Masonic tract from 1798, not so subtly accused the Freemasons of being communists in their introduction to the new edition. The book was originally published as a denunciation of the llluminati; John Robison, Proofs of a Conspiracy (Boston: The Americanist Classics, 1967) vii-xiv; The Illuminati were a group of Bavarian Freemasons who were suppressed in 1785 for conspiring against the Bavarian government; Peter Partner, The Knights Templar and their Myth, 125-6.

14 Helen Nicholson, "Knights and Lovers: The Military Orders in the Romantic Literature of the Thirteenth Century," in The Military Orders, 340-5. For the origins of chivalry; Maurice Keen, Chivalry (New Haven: Yale University Press, 1984), 2-5, 109. 
which is anachronistic. The Temple, for the most part, predated these chivalric notions, and may even have inspired writers to create them.

Fourth, each of these groups was formed, or reformed, to address an idea which was problematic in their day. Now, people use veneration of these groups to reclaim beliefs and ideas which they feel are missing from their lives, and the surrounding culture. The Druids, for example, became the rallying point for resistance to Roman rule after they fled to England from Gaul. 15 The Crusades attempted to convert the violent, lawless elements of Christian society into protectors of society from external, and later, internal, threats. ${ }^{16}$ The Templars expanded upon that belief by creating a police force for pilgrims which used military solutions but was bounded by monastic ethics. Small wonder that soldiers and policemen have been attracted to revivals of this Order. 17

Unfortunately this wedding of monastic and military rituals touched on old taboos concerning the priesthood and the pollution of shedding human blood in anger. They also validated priests who put aside their habits to participate lustily in battle, in direct violation of their vows. Such priests were not part of the "New Knighthood" which St. Bernard discussed in his famous tract. 18 Thus, this idea has remained semi-heretical, despite its popularity as a way (like Zen Buddhism) to redeem warriors.

15 John Wacher, Roman Britain (London: J.M. Dent \& Sons Ltd., 1978 ) 27, 217.

16 Ronald Finucane, Soldiers of the Faith, 12, 17-19.

17 George Washington, Benjamin Franklin, and Andrew Jackson were all Freemasons. Many officers in the Continental Army used Freemasonry to enhance their social mobility during the Revolution; Steven C. Bullock, Revolutionary Brotherhood: Freemasonry and the Transformation of the American Social Order, 1730-1840 (Chapel Hill: University of North Carolina Press, 1996), 1-2, 124-30.

18 Georges Duby, The Three Orders, 226-31. 


\section{The Masonic Temple}

The first, largest, and most influential neo-Templar group was, of course, Freemasonry. Beginning some time in the late 17th century (the "Grand Lodge of England" came out publicly in 1717), the Freemasons traced their descent, from the designer of the original Temple of Solomon, through medieval mason's guilds; hence, their name. 19

No one is quite sure when, or where, the first Masonic Lodge, from which sprung all others, was founded. Most writers ascribe Scottish origins to the Freemasons. 20 Others say that the English Lodge of 1717 was the first one, or that Freemasonry began in France, or even Germany. Rival lodges tended to split along national grounds. That the movement was very popular in all three of these regions, during the 18th century, is not in doubt.21

As the Freemasons attracted more aristocratic members, and acquired aristocratic ambitions of their own, they began to claim descent from the medieval Knights Templar, as well. This movement originated in Germany. There, a more conservative culture prompted Freemasons to deemphasize the more subversive aspects of the Masonic Temple and introduce more feudal trappings than those found in lodges from other countries.

The German Freemasons began to call themselves 'Templars,' and claimed to possess esoteric knowledge handed down from the Temple's last Grand Master, Jacques de Molay. They also created the Masonic concept of "grades of vengeance." 22 In this way, they identified Molay with Hiram,

19 David Stevenson, The Origins of Freemasonry: Scotland's Century, 1590-1710 (Cambridge: Cambridge University Press, 1988), 3-4.

$20 \mathrm{Ibid}$., 5-12.

21 Jacob Katz, Jews and Freemasons in Europe, 1723-1939, trans. Leonard Oschry (Cambridge: Harvard, 1970), 11.

22 This is a remarkable claim, considering that the historical Jacques de Molay was a hardheaded soldier's soldier who was functionally illiterate; Malcolm Barber, The New Knighthood, 285-6. 
architect of Solomon's Temple, and a mythical First Freemason, who was murdered for his trade secrets; Hiram's murder is ritualistically enacted in Masonic ceremonies of initiation. The Templars, having their former headquarters on the Temple Mount, were logical successors to the legendary Hiram.

The German Templars also claimed that the historical Templars had possessed knowledge passed down from the Essenes, a first century Jewish sect whose ideas inspired the Gnostics. This was an early connection of a neo-Templar group with the myths of the historical Templars' arabization. 23

Templarism was also popular in England and France, although the movement appears to have waned by the mid-19th century. Sir Walter Scott's novels Ivanhoe and The Talisman created interest in the Order, despite their jaundiced view of the Templars; Scott appears to have greatly preferred the Hospitallers to the Templars. It even became fashionable for people to dress as Templars when attending costume parties. 24

In theory, membership in a lodge of the Freemasons was open to all adult men who professed a belief in a supreme being, opening membership to all religions, but not to atheists. There were "adoptive" and "androgynous" lodges for women, but they were not well-respected in the movement. Some lodges (although not all) accepted Jews, and African-Americans.25 Some Masonic-

23 Peter Partner, The Knights Templar and their Myth, 110-14.

24 Elizabeth Siberry, "Victorian Perceptions of the Military Orders," in The Military Orders, 36572.

25 Jews have participated in lodges (or created their own) since the 1720's; Jacob Katz, Jews and Freemasons in Europe, 202-4. The first African-American lodge was founded in 1775 by Prince Hall, a Free Black, who attacked slavery, supported the Revolution, and encouraged both slaves and Free Blacks to join his lodge. Soon after its founding, the Prince Hall Lodge was recognized by a British lodge which was possibly trying to garner support for the British cause among Free Blacks; Loretta J. Williams, Black Freemasonry and Middle-Class Realities (Columbia: University of Missouri Press, 1980),12-15. For women in Freemasonry; Charles William Heckethorn, The Secret Societies of All Ages and Countries, vol. 2, 83-90. 
type groups were far less tolerant than the ideal, however. One renegade branch became the Ku Klux Klan in the 1870's.26 In later years, the Klan has been regrettably successful in recruiting white Masons into its organization. Not all Masons supported the Civil Rights movement in the 1960's, and they found the rituals of the Klan, in a changing world, comfortingly familiar.27

The Masonic Temple was, and is, a secretive organization. Many rituals of the group are closed to outsiders. It is necessary to undergo an initiation in order to attain membership. After the initiation, a Mason must earn a series of 'grades' which represent the steps on his path to enlightenment. Unlike the Templars, who maintained a certain amount of secrecy for military reasons, the secrecy of the Masonic Temple appears to exist to foster an air of mystery about the organization. According to the Freemasons, the purpose of their rituals is to increase spiritual enlightenment. To disclose these ceremonies to the initiated is useless, or even dangerous, to them. The secrets of Freemasonry are not especially well-kept, however, since Masonic authors sometimes publish books about them for the edification of other Masons. 28

Some outsiders have imputed less benign motives to the Freemasons'

26 The original Klansmen were not part of a lodge, but instead, borrowed Masonic rituals for their own organization; Steven C. Bullock, Revolutionary Brotherhood, 317. Racism and unconscious arabization go hand in hand in such groups. The Klan's book of rituals, created during its first revival in the 1920's, was called "the Kloran." The Klansmen were white Protestants who hated African-Americans, Jews, and Catholics (because many of them were immigrants) as disruptive outsiders. Klan vigilantes saw themselves as medieval Crusaders, sweeping in on horseback to cleanse the South of pernicious, alien influences. The irony of naming their rituals book after the Muslim Koran, however, appears to have completely escaped their notice. Also, the Klan's trademark burning cross has made it clear that De Nogaret's and the medieval Church's knee-jerk images of heresy have been radically altered in a culture where race is as incendiary a subject as religion; David Annan, "The Ku Klux Klan," in Secret Societies, ed. Norman MacKenzie (London: Aldus Books, 1967), 276-9, 296.

27 Governor Ross Barnett of Mississippi, Govemor Wallace of Alabama, and Governor Faubus of Arkansas (all opponents to the Civil Rights movement) were Freemasons; Loretta J. Williams, Black Freemasonry and Middle-Class Realities, 76-7.

28 Walton Hannah, Darkness Visible: A Revelation and Interpretation of Freemasonry (London: Augustine Press, 1953), 16-19. 
secretiveness than simple mystification. In 1826, Freemasons in New York were accused of kidnapping and murdering a former member who had published some of the Masonic Temple's mysteries in a book.29 A group related to the Freemasons, known as the Illuminati, was accused of trying to overthrow the government in the Holy Roman Empire during the 1780 's. ${ }^{30} \mathrm{~A}$ book published in 1977 put forth the theory that Jack the Ripper was actually a group of Freemasons, connected to the British royal family, who were trying to protect the Prince of Wales from the scandal of fathering an out-of-wedlock child. 31

Most recently, Freemasons have been accused of having undue influence on the educational system in the United Kingdom and trying to subvert the government in Russia.32

\section{Holy Warriors}

A remarkable offshoot to belief in the Templars is the conviction that they possessed legendary Christian relics. The two most notable of these relics are the Holy Grail and the Shroud of Turin.

Since the Grail is an entirely legendary (and allegorical) relic, the Templars' connection to it is far more tenuous to it than their circumstantial link to the Shroud. The first writer to attribute possession of the Grail by Templars was Wolfram von Eschenbach in the 13th century. In his version of 29 lbid., 22-3.

30 Peter Partner, The Knights Templar and their Myth, 126-7.

31 Stephen Knight, Jack the Ripper: The Final Solution (St. Albans: Panther, 1977).

32 Linda Blackburne, "Fear of the Not So Secret Brothers (Masonic Lodges and Schools)," Times Educational Supplement, no. 4019 (July 9, 1993), p. 8; "Freemasons Are Not Interested in Politics, "Moscow News, no. 33-6 (September 15, 1995), p. 22. 
an Arthurian tale, Parzival, Wolfram referred to the guardians of the Grail as

Templeisen. While the actual connection which Wolfram imputes is tenuous, at best, his intended pun was quite clear to his audience. 33

Some modern writers conflate the Grail with the Shroud (as the vessel of Christ's blood), ${ }^{34}$ while another modern Grail story, Indiana Jones and the Last Crusade, renames Wolfram's Grail guardians "The Knights of the Cruciform Sword."35 The connection between the Templars and the Grail, however, is as legendary as the Grail, itself.

The connection between the Templars and the Shroud of Turin is more concrete, but still questionable. The link is in the similarity of the name of the Shroud's medieval "discoverer" Geoffrey de Charny, to that of Geoffroi de Charnay, the Preceptor of Normandy who was burned with Jacques de Molay as an relapsed heretic in 1314.36 The Templars, so the story goes, acquired the Shroud during the sack of Constantinople in 1204. Supposedly, they displayed the Shroud in their chapter meetings, but folded up so that only the head showed. This is what led to the rumors about the Templar worship of a head. Some writers have pointed out that the coincidence of a name is not sufficient evidence to connect the Templars to the Shroud. 37

The first writer to connect the Templars to the Shroud appears to have

33 Jessie L. Weston, The Quest of the Holy Grail (New York: Barnes \& Noble, Inc., 1913; reprint, 1964), 134-7; Wolfram von Eschenbach, Parzival, trans. André Lefevere (New York:

Continuum, 1991), xiv, 213-222. Lefevere translates "Templeisen " as "Templar."

34 Katherine Kurtz, "Obligations," in Tales of the Knights Templar, ed., Katherine Kurtz (New York: Warner Books, 1995), 96-128.

35 Steven Spielberg, Indiana Jones and the Last Crusade, directed by Steven Spielberg, 126 min., produced by Lucasfilm Ltd., 1989, videocassette. These Knights all have crosses tattooed on their chests, which calls into question their professed secrecy.

36 Rodney Hoare, The Turin Shroud is Genuine: The Irrefutable Evidence, 2nd ed. (New York: Barnes \& Noble Books, 1994), 32-6. This book was originally published in 1984 under the title A Piece of Cloth.

37 Malcolm Barber, "The Templars and the Turin Shroud," The Catholic Historical Review, 68 (1982), 206-25. 
been lan Wilson in his book The Shroud of Turin: The Burial Cloth of Jesus

Christ?38 Published in 1978, Wilson's book predated the testing done on the Shroud by a U.S. Shroud of Turin Project (STURP). One of the scientists on the Project, John Heller, published his own conclusions in Report on the Shroud of Turin, claiming that the stains on the Shroud were blood, but that the authenticity of the relic needed to be confirmed by radiocarbon testing. 39 In 1988, radiocarbon testing confirmed that the Shroud had been created between 1260 and 1390. Shroud debunkers, especially those who had believed that the stains on the Shroud were painted, felt vindicated by this finding and insisted that all further discussion of the Shroud was irrelevant. Never mind that questions have since arisen concerning the quality and accuracy of the radiocarbon dating. 40 Never mind that the Shroud has been definitively confirmed as authentic to the point of its first appearance in historical records--1389. This makes it an authenticated medieval relic (and those are very rare). More importantly, it is a relic which dates from the period of the Black Death, which was a time of great trouble in Europe, and it appears to be unique.

All this aside, the motivations of the Charny family in displaying the Shroud

38 lan Wilson, The Shroud of Turin: The Burial Cloth of Jesus Christ? (New York: Doubleday \& Company, Inc., 1978), 153-83. Wilson claims that the Charny family displayed the Shroud publicly in 1389 in an effort to revive the Order of the Temple.

39 John H. Heller, Report on the Shroud of Turin (Boston: Houghton Mifflin Company, 1983), 206-221. An outside scientist who conducted his own tests on the Project's sample disputed the positive tests for bloodstains; Joe Nickell, Inquest on the Shroud of Turin (Buffalo:

Prometheus Books, 1983), 141-7.

40 Walter C. McCrone, Judgment Day for the Turin Shroud (Chicago: Microscope Publications, 1996), 246-51. Some reacted oddly to the news. Two authors even proposed that Leonardo da Vinci (in this story he is also a Goddess-worshipper) created the Shroud, even though the radiocarbon dating makes this theory very unlikely; Lynn Picknett and Clive Prince, Turin Shroud: In Whose Image? (New York: HarperCollins Publishers, 1994), 180-6; Others claimed that the scientists who had conducted the radiocarbon testing conspired to make the Shroud look like a fake; Holger Kersten and Elmar R. Gruber, The Jesus Conspiracy: The Turin Shroud and the Truth About the Resurrection (Rockport: Element, 1992), 319-23. 
have yet to be explained, and the connection of the Shroud (genuine or not) to the Templars remains unconfirmed. Considering the current level of scholarship and objectivity in the field, these two questions are likely to remain unanswered for some time.

\section{Templars on TV}

The Knights Templar are a popular group with television documentary producers. Several programs have been produced about the Order in the 1990's, as well as programs on related subjects such as the Shroud of Turin, the Holy Grail, the Masonic Temple and heretics. The quality of these programs ranges from good, albeit simplistic, to bad, to horrible. Occasionally, fictional shows like Highlander: The Series, Inspector Morse, or Law and Order mention the Templars, but most of the programs which do so are documentaries.

\section{The Unexplained: Sacred Societies 41}

This documentary examines neo-Templars in Scotland and the United States, and Druids in Northern Ireland, and the United States. For the Templar segment, there are interviews with John Ritchie, member of the Scottish Order of Knights Templar, Keith Laidler, author of The Head of Christ, Frank Welter, member of the Chicago Knights Templar (a Masonic chapter), and Stephen Dafoe. The segment is sensationalist in tone, and portrays the Templars as mystics, heretics, and magicians. The Temple's history is sketchily presented,

41 "Sacred Societies," The Unexplained, written and produced by Neil Laird, 40 min. Tower Productions Inc. for the A\&E Network, 1999. 
with odd, factual errors. 42

There is a lively discussion about the legend that the Templars kept a head as a relic. Welter insists that the skull which his chapter possesses has no mystical connotations: "The head is part of the ceremonies and there are lessons to be learned from it." Laidler, on the other hand, is convinced that the Templars kept the head of Christ, and that this head is buried under Rosslyn Chapel (the burial ground for a noble, Scottish family called Sinclair), which is a shrine, of sorts, for neo-Templars. Ritchie disputes Laidler's notion, but only because he, himself, is obsessed with Rosslyn Chapel, and therefore has his own ideas about what is inside it. Ritchie feels that Laidler cannot properly understand either Rosslyn Chapel or the historical Templars because he is not an initiate into the modern Order. This territoriality is common from neoTemplar groups. Outsiders are often ridiculed for their ideas about the Templars.

The discussion ends with Dafoe, the show's designated debunker, who notes that it is unlikely that the head of Christ exists as a relic, or that the Templars had it. Even if they did have such a head, it was almost certainly not authentic, or unique. "Religious relics," notes Dafoe, "were probably as common [in the Middle Ages] as beanie babies are today."

\section{The Shadow of the Templars 43}

This documentary is essentially a $\mathbf{4 0}$ minute-long advertisement for the narrator, Henry Lincoln's, book Holy Blood, Holy Grail. He also mentions the

42 The program asserts, for example, that the Masons do not claim descent from the medieval Templars, then fails to explain the existence and nature of Masonic Templars. It also claims that the idea of the number 13 being bad luck originated from the fact that the Templars were arrested on Friday the 13th.

43 "The Shadow of the Templars," Ancient Mysteries, written and narrated by Henry Lincoln, researched by Richard Leigh, Michael Baigent, Anthony Walls, and Jania MacGillivray, 40 min. BBC [A\&E Channel], 1979. 
documentary in a later book, The Messianic Legacy. 44 In both book and documentary, Lincoln claims that Jesus had children and that the Holy Grail is really a codeword for the bloodline of his descendants (which, he claims, persists to this day in a man called Pierre Plantard de Saint-Claire). The correlation between the Sinclairs and Pierre de Saint-Claire is obvious, but Lincoln mercifully does not make it.

The actual intended connection to Templars is difficult to decipher. Lincoln claims that the Templars sprung from a shadowy parent group, the "Order of Sion," which survived the Templars' suppression to become the "Prieure de Sion: Ordre de la Rose-Croix (Rosicrucians)." The Rosicrucians are actually a group whose origins were contemporaneous with those of the Freemasons. 45 The cinematography is washed out and the sound is only slightly better than that in an Italian spaghetti western. Worse yet, for the curious neo-Templar, it is dull.

\section{In Search of History: The Knights Templar46}

This is the most accurate of the Templar documentaries currently in circulation. The program interviews Anne Gilmour-Bryson, author of Sodomy and the Knights Templar, and uses her as a Historical Consultant. It also interviews Malcolm Barber, author of The New Knighthood, Edward Peters, John Ritchie, Henry Lincoln, Daibidh Wallace, inductee of the Scottish Knights Templar, and Jennifer Grant, Chancellor of the Scottish Knights Templar.

The most intriguing part of the documentary comes when Gilmour-Bryson discusses the Templars' relationship with Usamah Ibn Munqidh. Usamah's

44 Michael Baigent, Richard Leigh, and Henry Lincoln, The Messianic Legacy (New York: Dell Publishing, 1986), 234.

45 Peter Partner, The Murdered Magicians, 120.

46 "The Knights Templar," In Search of History, produced by Steven R. Talley, 40 min. FilmRoos Inc. for the History Channel, 1997. 
famous story is related, and Gilmour-Bryson interprets it to mean that the Templars were heavily arabized. The program then states that some Templars visited Muslim courts, and learned Arabic. Unfortunately, the narration, which is of much lesser quality than the interviews, goes on to contradict itself by insisting that, despite their "extensive connections" with Islam and Judaism, the Templars were religious fanatics. Some of the footage from this documentary was later used in the Unexplained segment. Some ideas from this documentary (the legend of the Templar arrests on Friday the 13th and the relic of the head) were also repeated from this documentary in the Unexplained segment.

\section{Ancient Warriors: The Knights Templar47}

This is a fairly straightforward, albeit brief, history of the Order. It benefits from having Malcolm Barber as a Specialist Consultant. There are some factual errors, and the program is chronologically confusing. The narration claims, for example, that Hugh de Payens and Godfrey de Saint Omer (two of the original nine Templars) took their vows during the First Crusade (1095-99) rather than two decades later in 1119. It also tells the story of Gerard de Ridefort, yet skips the battle of Hattin. There is an imprecise mention of the Rule and much vague discussion about the Third Crusade. The program claims that the Templars had a complement of 20,000 men (the In Search of History segment makes this mistake, as well) whereas the actual number of Templars probably never exceeded 5,000.48

The program is distinguished by excellent cinematography, including footage of two uncredited stained-glass windows of the Seal (which do not, however, look medieval).

47 "The Knights Templar," Ancient Warriors, written, directed, and produced by Phil Grabsky, 20 min. Seventh Art Productions for The Learning Channel, 1994.

48 Malcolm Barber, The New Knighthood, 93-5. 


\section{Terra X: The Knights Templar49}

This half hour segment has excellent cinematography of Templar sites in Spain, but execrable history. The program focuses on the Spanish Templars, although it does not make clear that the Order existed elsewhere. It implies that the Order began in 1212, not 1119. The segment accuses the Templars of alcoholism, debauchery with women, sodomy (citing the Templar Seal's symbol of "two riders on one horse"), and drug abuse. The program claims that the Templars were accused of worshiping a black cat, or idol, long before the Trial, and claims that a roseate structure in one of the windows at a Templar church in Castanillo is really a pentacle. This, the program asserts, associates the Templars with the Druids.

Arabization in the architecture is also mentioned, implying that the Templars, Druids, and Muslims are all, somehow, linked. The supposedly heretical initiation ceremony (where the new Templar was forced to spit on a crucifix) is reenacted. In the scene, a young initiate refuses to desecrate the cross and is thrown down a long, sloping passageway that ends high above the ground. The program does not consider that a wooden structure may well have existed at the end of the passage. The passage, if anything, looks more like a large drainage pipe than an elaborate execution device.

The program is saved by some excellent, but, unfortunately, uncredited cinematography. Other than that, the program is only useful as a sobering example of how long certain types of propaganda can last, unchallenged, in popular myth.

\section{Ivanhoe}

Walter Scott's book Ivanhoe has probably created the most indelible image of the Knights Templar, that of Brian de Bois-Guilbert, the renegade, arabized 49 "The Knights Templar," TerraX. 
Templar. The book has spawned three major adaptations: a film in 1952,50 a tv movie in 1982,51 and a miniseries in 1997.52 The first movie is straight adventure, with little adherence to Scott's plot. The 1982 version is the most faithful to the book. The 1997 version is the most faithful to the reality of the Templars and the Middle Ages.

Scott disliked the Templars, and was startled by the popularity of the doomed Templar Brian de Bois-Guilbert's one-sided love affair with the Jewish physician Rebecca. Bois-Guilbert dominates the story, whereas the eponymous hero, Sir Wilfred of Ivanhoe, only appears in about one third of the book. Bois-Guilbert appears in the storyline before Ivanhoe, and it is his death (by the hand of God, not Ivanhoe) which is the climax of the book. Whereas Ivanhoe spends most of the book sick in bed, Bois-Guilbert, and his reluctant lover, Rebecca carry most of the plot. In the movie versions, Ivanhoe is much more active; Bois-Guilbert always dies by his hand, not God's.

Scott had intended for the portrayals of Ivanhoe and King Richard Coeur de Lion to dramatize the reconciliation between the conquered Saxons and their Norman overlords in the Middle Ages. He was chagrined to find that the Templar connection-- the forbidden relationship between Bois-Guilbert and Rebecca, and Rebecca's subsequent trial at the hands of the Templar Grand Master--was the real attraction of the story. 53 He made certain that in his next novel concerning the Templars, The Talisman, that the Grand Master would be a villain with none of the virtues of either Bois-Guilbert or Ivanhoe's own

50 Ivanhoe, written by Noel Langley, directed by Richard Thorpe, produced by Pandro S. Berman, 107 min., Metro Goldwyn Mayer Inc., 1952.

51 Ivanhoe, written by John Gay, directed by Douglas Camfield, produced by Norman Rosemont, 142 min., Columbia Pictures Television, 1982.

52 Ivanhoe, written by Deborah Cook, directed by Stuart Orme, produced by Jeremy Gwilt, 300 min., BBC TV/A\&E Home Video, 1997.

53 Sir Walter Scott, Ivanhoe, 4-8. 
fanatical Grand Master, Lucas de Beaumanoir.54 Unfortunately, this correction was less interesting than its more complicated original, and The Talisman has fallen into an obscurity which Ivanhoe has avoided.

Only in the movie versions where Bois-Guilbert is a secular knight, not a Templar, does Ivanhoe prevail in the storyline. The 1952 movie, and a children's adaptation of the story in the PBS series, Wishbone, try this solution to the Templar problem. Although both show extras in Templar-like dress, they do not identify them as Templars. Nor is Bois-Guilbert dressed as a Templar in either adaptation. 55 In these versions, the story becomes two-dimensional, and there is far less suspense about the ending than in the two versions which preserve Bois-Guilbert's status as a Templar. Without the Templar element, Ivanhoe becomes a simplistic adventure story like The Talisman.

This is probably because the compelling aspect of Ivanhoe is that the taboo in Bois-Guilbert's loving Rebecca lies not in the fact that she is non-Christian, but in the fact that he is a monk. Bois-Guilbert is a man who has been dead to love for 20 years. He is a walking killing machine who rediscovers his soul in his love for a forbidden woman, only to die from the irreconcilable differences of love and duty. Today, he would be a tragic hero, and this is what the 1984 and 1997 versions try to make of him.

The 1984 version (which has Sam Neill as Bois-Guilbert), adheres closely to the plot of the book, but not to historical accuracy regarding the Templars. Bois-Guilbert has no beard, and is seen, at one point, bathing publicly with two knights. He is, therefore, uncommonly clean for a Templar. Templars always wore short hair and grew beards, in direct contrast to the long-haired,

54 Sir Walter Scott, The Talisman: A Tale of the Crusaders (New York: Peter Fenelon Collier \& Son, 1900).

55 "Sniffing the Guantlet," Wishbone, written by Darla Opava, directed and produced by Rick Duffield, 20 min., Big Feats! Entertainment, 1995. 
and clean-shaven, knights of the 12th and 13th centuries. Also, a Templar would never disrobe in front of another person, even another Templar. Finally, Templars never bathed. 56

The 1997 version provides a much more realistic-looking Templar, in Ciarán Hinds, who is filthy, sweaty, bearded, dark, and sullen. Hinds gives a compelling, and sympathetic, portrayal of the villainous Bois-Guilbert. BoisGuilbert's wooing of Rebecca is much expanded from the book, and is not nearly as one-sided as in Scott's original novel.

Rebecca's trial also provides a chilling example of how medieval witch trials worked. Bois-Guilbert is thwarted at every turn by his brother Templars in his efforts to save Rebecca's life. At best, he is mad; at worst, he is also a witch and must be burned, as well. The manner in which he is rendered silent and helpless in the trial is a microcosm of what happened to the Templars in their own Trial. To be strictly accurate, however, it is more likely that Rebecca would have been tried for heresy than witchcraft. Witchcraft trials before the late 14th century were rare. 12th and 13th century inquisitors had different obsessions--heresy being high on their list. 57 The Templars, for example, were prosecuted for heresy, not witchcraft.

Unfortunately, the 1997 version has other historical inaccuracies, as well, and these are far more pernicious than those in the other versions. For example, at the beginning of the movie, Ivanhoe, who has just returned from the Third Crusade, relates a horrific story about a Templar who once rode through the streets of a captured town with the head of a dead girl impaled on his lance. Ivanhoe claims that the Templar raped the girl before he killed her.

This is, of course, pure fantasy. Such a man would forthwith be expelled 56 Stephen Howarth, The Knights Templar (New York: Barnes \& Noble Books, 1982), 120-1. 57 Malcolm Lambert, Medieval Heresy, 169. 
from the Order, and end his days in Château Pèlerin for having deserted his banner (\#232), had sex with a woman (\#236), and (possibly) killed a Christian (\#226). The lack of this type of criticism of the Order by pre-Trial sources indicates that if such incidents did occur, the Order's justice toward the offending brother was swift, public, and savage.

There is also the problem (which stems from the book) of why Bois-Guilbert is allowed to wander the English countryside for half of the story with two disreputable brigands. True, he is a Preceptor, an advisor to Prince John, and a future candidate for Grand Master, but historically, even a Master spent his days surrounded by brother Templars, and was responsible for his behavior to them. The movie also shows Bois-Guilbert striking a young Templar squire in anger. This, of course, would lose him his habit for a year (\#234), Preceptor or no Preceptor. The incident where he gives up information to save his own life and leaves Ivanhoe for dead is also uncharacteristic of a Templar, since he would be expelled for violating rule \#226. More to the point, it is internally inconsistent: Bois-Guilbert shows no signs of cowardice after the point in the movie where this flashback is shown. In fact, he shows considerable courage. The incident (which is not in the book) therefore makes no sense from the point of view either of history or the story. 58

The significance of the Templar image in lvanhoe rests, finally, in the perceived arabization of its anti-hero. Despite being a man who has killed 300 Muslims in single combat, Bois-Guilbert is heavily arabized in all of the versions which portray him as a Templar. At the beginning of the story, he has spent half of his life in the Holy Land, and does not understand European ways. He falls in love with a non-Christian woman. He is fluent, and literate, in three languages--one of them Arabic. His favorite horse is an Arab stallion 58 Sir Walter Scott, Ivanhoe, 310-13. 
named Zamor. In the 1997 version, he is bearded, resembling an Arab. His face is burnt dark from the sun of Palestine, and he moves and speaks with the hauture of a desert prince in a Victorian adventure novel. This is the most popular image of the Templars in today's society, and it is one that is intensely arabized.59

\section{Templars and the Internet}

The Templars are very popular on the Internet. The World Wide Web is an excellent source for original research on neo-Templar groups, since many of these groups have their own homepages, but it is worse than useless as a source for information on the historical Templars.

There is a wide range of Templar sites on the Web. Some are professional sites 60 (The Society for the Study of the Crusades and the Latin East (SSCLE), and the Middle East Medievalists (MEM), some are sites of products

59 Jack G. Shaheen, The TV Arab (Bowling Green: Bowling Green State University, 1984), 1217. On television, and in movies, Arabs are often seen as dark, violent, oversexed, arrogant, and fanatical. Bois-Guilbert fits this stereotype quite well.

60 The SSSCLE is a group of Crusades scholars and students, which includes such well-known Templar historians as Malcolm Barber and Helen Nicholson. Michael Markowski, "Crusade Society: SSCLE," SSCLE Homepage, 8 January 1999, <http://www.wcslc.edu/pers_pages/mmarkow/ssclehome.html> (25 March 1999). MEM studies the medieval period from the Islamic point of view. It includes a listserv and shares some of its members with the SSCLE. Jane Maurer, "CSE History Dept: Middle East Medievalists," MEM Homepage, n.d., $<\mathrm{http}: / /$ www.colostate.edu/Depts/Hist/mem/index.htm/ (25 March 1999). 
the Templars (ORB Index is an excellent warehouse of primary sources in translation), 62 some are personal webpages providing the owner's take on the Templars, 63 some are homepages for local chapters of the Freemasons and related neo-Templar groups, 64 some are sites for the Society of Creative Anachronism (SCA), 65 some are sites devoted to the occult (Sollog's

61 Timothy Grayson, Templar Strategies Homepage n.d., <http://www.templar.ca/> (25 March 1999). Templar Strategies is a recently formed (1996) consulting company, based out of Canada, which specializes in introducing businesses into foreign countries, and helping politicians set up their campaigns. The cross-cultural, and political intrigue, elements of the Templars legacy are prominent in this company's mission statement. "Introduction to Templar," PJO Publications inc. Homepage, n.d., <http://www.wenet.net:81/ pjopubs/example.html> (25 March 1999). Templar is a security system "that allows the secure and reliable transmission of EDI documents over an open network, such as the Internet." The metaphor is clear: just as the medieval Templars protected pilgrims traveling through the Holy Land, Templar will protect your email as it travels through cyberspace.

62 Conrad Greenia, "St. Bernard of Clairvaux's In Praise of the New Knighthood," ORB Index, 1996,<http://orb.rhodes.edu/encyclop/religion/monastic/bernard.html> (25 March 1999); Judith Upton-Ward, "Military Orders: The Primitive Rule of the Templars," ORB Index, n.d., $<\mathrm{http}$ ://orb.rhodes.edu/encyclop/religion/monastic/T_Rule.html> (25 March 1999).

63 António Mendonça, "The Knights Templar in the Portuguese Discoveries," The Knights Templar, 1998, <http://www.euroknightstemplar.org/> (25 March 1999). This site is written in Portuguese, except for the opening page. Some of the graphics, alone (a raised relief graphic of the Templar seal in gold, interposed with a graphic of a 15th century ship, for example), are worth accessing the site. The author discusses the possible influence of the Order of Christ (the secular successor to the Temple in Portugal) on Portugal's explorations of Africa and the New World. Robert Walker, "The Templar Knights," The RobFAQ, 20 January 1999, $<$ http://www.iwaynet.net/ rwalker/templar.html> (25 March 1999). The author of this page was inspired to post his thoughts about the Order on the Internet after buying a replica of a Templar sword. The page has a brief, and essentially accurate, history of the Order, as well as some graphics of the Templar Seal, and other related objects. The best personal Knights Templar site was the Knights Templar Preceptory Portcullis, to which every Templar webpage with a decent list of sites had a link. This was an extensive site, with considerable, and straightforward, information on the Order. The author's main source appears to have been J.M. Upton-Ward's translation of the Templar Rule and St. Bernard's In Praise of the New Knighthood. Unfortunately, the site was shut down, without explanation, in Fall 1998. 64 Fr. Galahad, "Knights Templar Oasis," Ordo Templi Orientis: U.S. Grand Lodge, n.d., <http://www.kto.org/> (25 March 1999). This is the homepage for the Massachusetts branch of the Ordo Templi Orientis (Order of Oriental Templars). The OTO is a Masonic-type neo-Templar group which was founded in 1904 by Aleister Crowley.

65 Joe Steffes, The Commandery of Antioch Title Page, 11 November, 1998, $<$ http://www.provide.net/ templar/s (25 March 1999). This is the homepage of an SCA-related group which recreates the Crusades, with an emphasis on the Templars, and other military orders. 
Grail), 67 and some are by borderline groups who use the Templars as

symbols for some very disquieting beliefs. Most notable of these last sites is the homepage for the skin-head group, "The Templars."68

Neo-Templars have a very manichaean view of the historical Order. They often perceive the historical Templars as warriors of light (or darkness, depending upon their beliefs) in a perpetual war against an evil that is easily

66 ASSI Publishing, T.E.M.P.L.A.R. (Theology of the Egyptian Magi Priests Loyal to the Ancient Rites), Sollog's Homepage, 1999, <http://www.sollog.com/book-templar.shtml> (25 March 1999). This is a book advertisement on the homepage of the self-proclaimed prophet, Sollog. Not only does Sollog connect the Templars with ancient Egyptian priests, but he has also posted allegedly authentic photographs of Princess Diana Spenser's fatal car crash and the autopsy on John F. Kennedy. The site is venerable, for the Internet, having been created in 1995. According to the webcounter, the site has been viewed 184,361 times since its creation. This popularity is probably what recently prompted the mysterious Sollog to begin charging for access to certain portions of his site.

67 William F. Mann, "The Knights Templar and the "Holy Grail' in Nova Scotia," The Labyrinth of the Grail, n.d., <http://www.gate.net/ grupo/grail.html> (25 March 1999). This is an old site, dating from 1994, but it is updated regularly. The author of this webpage claims that the Knights Templar fled to Nova Scotia with their secret treasure, the Holy Grail. The site includes many references to the Tarot and Masonic geometry. The author is publishing a book of the same name, and the same subject, in Fall 1999. The publisher, Laughing Owl Books, has also published a historical novel, Song of the White Swan, by Aleta Boudreaux, which postulates the continued existence of goddess-worship, and Templars, in 15th century France; Laughing Owl Bookstore, 23 March 1999, <http://www.laughingowl.com/s (25 March 1999). Another online publisher, Templar Books, has published The Warriors and the Bankers: A History of the Knights Templar from 1307 to the present, by Alan Butler and Stephen Dafoe, which discusses the possibility of Templar survivals, and offers several other books, scholarly and otherwise, concerning Templars, Freemasons, and the Crusades; Stephen Dafoe, "A History and Mythos of the Knights Templar," Templar Books, n.d., <http://intranet.ca/ magicworks/knights/next.html> (25 March 1999).

b il emplars Main Page," Templars Homepage, n.d., <http://www.geocities.com/SunsetStrip/Palms/4907/page2.html> (25 March 1999). "The Templars" do not appear to be overtly racist, like many skinhead groups. There are references in some of their song lyrics to solidarity between races and one of them, Phil, looks AfricanAmerican in the band photograph on their website. But, they are also very, very angry. There is considerable hostility toward authority figures, such as police and politicians, in their lyrics. The group also discusses class warfare, and skinheads' perceived lack of economic, social, and political mobility, at length. All of their lyrics, especially their theme song, "The Templars," display a siege mentality. "The Templars" are obsessed with their namesakes, as demonstrated in their song and album titles (Return of Jacques de Molay Poor Knights of Acre, Omne Datum Optimum). Lyrics indicate that they identify with the historical Templars as martyrs who were betrayed by their own side in a manichaean conflict with the evil Muslims. 
their match.69 They also see the Templars as mystics and/or sorcerers with esoteric knowledge of the mysterious East.

Despite the fact that many of the myths that neo-Templars use in their rituals and symbols were clearly fantasies that medieval Christians had about medieval Muslims, neo-Templars usually shy away from making a direct connection between the Templars and the Muslims (with the sole exception of the Assassins). Instead, they link the Order to biblical architects, ancient Egyptian priests, Druids, and Zoroastrians. There is a distinct uneasiness with making the arabization of the Templars too direct.

Regardless of the accuracy, or inaccuracy, of their perceptions of the Order, people will continue to seek inspiration from the medieval Templars, however indirectly. How much difference is there, in the end, between the Templars' original mission to guard pilgrims against infidel marauders, and the missions of the Red Cross, or the U.S. Peace Corps, or Doctors without Borders, or Amnesty International, or a dozen Non-Government Agencies (NGO's)? Like the Templars, these groups, when inspired by abstract concepts of a crusade against communism, disease, hunger, injustice, or torture, chose an underlying cause to their problem and set out to eradicate it in a practical, sensible manner. Such groups may be the true heirs to the Templars.

On the other hand, one must not forget the shadowy side of the Templars' memory. For the past three centuries, certain groups have seen the Templars

69 Katharine Kurtz, The Adept, Book Three: The Templar Treasure (New York: Ace Books, 1993). The Adept series is about a Scottish nobleman named (naturally) Adam Sinclair who leads a mystical "hunting lodge" against the forces of evil. The antagonists are generally druids, or some type of germanic neo-pagans. Sinclair is the reincarnation of a medieval Templar, who was burned at the stake during the Trial after aiding another Templar escape France with the Shroud of Turin. In The Templar Treasure, Sinclair must prevent a French scholar (who happens to be the reincarnation of Guillaume de Nogaret) from releasing the twin demons Gog and Magog upon the world. Despite often graphic depictions of occult evil, the book retains a certain innocence through its portrayal of the conflict of good and evil in absolute terms. There are no moral gray areas in the Adept's world. 
as symbols of rebellion and justifiable paranoia. Perhaps it is best to end this short survey of the Templars' posterity with the words of one of these groups, the skinhead band, "The Templars."

The Templars 70

"Charging into battle and showing no fear

Courageous holy warriors with sword and spear

Fighting to the last, they never fear death

For on the field of battle they are put to the test

CHORUS

Stand strong, young warrior, to your beliefs

Never admit to your own defeat

Warriors of the sword, when your power is too great

The ones you protect are the ones who seal your fate

Scarlet cross on a field of white

Fighting for what they believe is right

Punished by the church and the state

Condemned to die, burning at the stake

CHORUS

Feudal warriors dealing with a hostile foe

Sword raised high to deal the death blow

False charges brought the warriors to an end

Greed and lust, a means toward the end

CHORUS

Independent spirits brought about their demise

70"Lyrics," Templars Homepage, n.d.,

<http://www.geocities.com/SunsetStrip/Palms/4907/page2.html> (25 March 1999). 
Tortured and killed for denying their lies

Never lose hope and never give in

Stick to your guns and fight, fight to win."

Is this the true legacy of the Poor Knights of the Temple of Solomon? 


\section{CONCLUSION}

The arabization of the Knights Templar was of two types: real and imagined. While real examples of Templar arabization in the Holy Land aroused the occasional ire of Europeans back home, it was never serious enough to threaten the Order itself. Spanish Templars do not appear to have suffered from such criticism. This is perhaps because the Holy Land was seen as a collective possession by most Latin Christians, whereas the territory of Christian Spain was seen as the property of the Spanish realms.

Real Templar arabization was a reaction to local conditions. Despite incidents of friendship between Templar and Muslim, the Templars associated with Muslims not because of any special tolerance in their nature, but because it was necessary, in order to preserve, and expand, the Christians' grasp on the Holy Land. For the same reason, Templars learned how to fight, and, therefore, think like their Muslim foes, as well. There was no other way to survive in the early days when they were poor and had to severely husband their resources.

Yet, throughout their history, the Templars did show signs that they might some day come to a permanent rapprochement with their enemies. Some Muslims, like Usamah Ibn Munqidh, recognized this in the Order, and approved of it. The Templars themselves did not live to see the persecutions which European Christians practiced against Muslims and Jews in the latter 
part of the Middle Ages.

It was, in fact, the perceived arabization described in Guillaume de Nogaret's charges at the Templars' Trial that destroyed them, and it has been this perceived arabization which has entered public consciousness as the "true" image of the Knights Templar. The denial of Christ, the desecration of the cross, the charges of obscene kisses and sodomy, and the adoration of an idol, or relic, in the shape of a head or a cat, were all common European misconceptions about Islam.

They were also charges that were frequently levelled against heretics, an internal enemy. The charges were a way for the French government to condemn, and destroy, representatives of the hated Muslim enemy (the Templars) without prompting an actual crusade to the Holy Land. The persecution of the Templars was not an isolated phenomenon, but was part of a pattern of attacks which Philip and his ministers made on convenient targets throughout his reign. In this way, Philip could relieve the debts which always pressed upon his treasury, while making himself look, and feel, like a "most Christian King."

European Christians had some access to information about real Muslim practices, but instead chose to believe in their own fantasies. Many neoTemplars, confusing the fantasies of medieval Christians about medieval Muslims with reality have tried to emulate the medieval Templars by propagating De Nogaret's charges through elaborate myth and ritual. Certainly, there is no proof in the Templar Rule that such practices ever existed among the historical Templars.

On the other hand, some groups have still preserved the original ideals of the Templars. This indicates that the desire, over the past three centuries, of 
some people to recreate themselves in the image of these medieval monks/knights is no fluke. The Templar ideal which gave so many fighters of the Middle Ages hope that they could attain Paradise still has the power to inspire people, and its new life comes from the historical Templars' arabization--both real and perceived. Both those who love, and those who hate, the Templars see the Order of the Temple as a cultural bridge between two faiths. This is a powerful image in an era which is plagued with religious and political fundamentalism.

Paradoxically, however, the historical Templars are also seen as religious fanatics, magical knights in a simplistic, manichaean world. Depending on the author, they are portrayed either as forces of Light, or demonic forces of chaotic evil. This, of course, does not coincide with the clear signs of the historical Templars' assimilation into local, Muslim culture, or with the dark, crypto-Muslim fantasies constructed by De Nogaret. Many neo-Templars, consequently, cloak the medieval Templars' arabization by setting its origins in the distant past--long before the birth of Islam.

This mutes the power of the recreated Templar ideal as a cultural bridge, however, and has led to Templarism in unlikely quarters (skinheads, the Ku Klux Klan, the German Nazis, etc.). Such willful blindness creates a dangerous synergy for certain types of people in today's society. The majority of neo-Templars are harmless, even benevolent, but the fringes of the movement bear watching. 
APPENDIX A:

USAMAH IBN MUQIDH AND THE TEMPLARS 


\section{USAMAH IBN MUNQIDH AND THE TEMPLARS}

Everyone who is a fresh emigrant from the Frankish lands is ruder in character than those who have become acclimatized and have held long association with the Moslems. Here is an illustration of their rude character.

Whenever I visited Jerusalem I always entered the Aqsa Mosque, beside which stood a small mosque which the Franks had converted into a church. When I used to enter the Aqsa Mosque, which was occupied by the Templars [al-dawiyyah], who were my friends, the Templars would evacuate the little adjoining mosque so that I might pray in it. One day I entered this mosque, repeated the first formula, "Allah is great," and stood up in the act of praying, upon which one of the Franks rushed on me, got hold of me and turned my face eastward saying, "This is the way thou shouldst pray!" A group of Templars hastened to him, seized him and repelled him from me. I resumed my prayer. The same man, while the others were otherwise busy, rushed once more on me and turned my face eastward, saying, "This is the way thou shouldst pray!" The Templars again came in to him and expelled him. They apologized to me, saying, "This is a stranger who has only recently arrived from the land of the Franks and he has never before seen anyone praying except eastward." Thereupon I said to myself, "I have had enough prayer." So I went out and have ever been surprised at the conduct of this devil of a man, at the change in the color of his face, his trembling and his sentiment at the sight of one praying towards the qiblah.

Translation of the Memoirs of Usamah Ibn-Munqidh by Philip Hitti in 1929.1

1 Usamah Ibn Munqidh, An Arab-Syrian Gentleman and Warrior in the Period of the Crusades: Memoirs of Usamah Ibn-Munqidh, trans. Philip K. Hitti (New York: Columbia University Press, 1929), 163-4. 
This is an example of Frankish barbarism, God damn them! When I was in Jerusalem I used to go the Masjid al-Aqsa, beside which is a small oratory which the Franks have made into a church. Whenever I went into the mosque, which was in the hands of Templars who were friends of mine, they would put the little oratory at my disposal, so that I could say my prayers there. One day I had gone in, said the Allah akhbar and risen to begin my prayers, when a Frank threw himself on me from behind, lifted me up and turned me so that I was facing east. 'That is the way to pray!' he said. Some Templars at once intervened, seized the man and took him out of my way, while I resumed my prayer. But the moment they stopped watching him he seized me again and forced me to face east, repeating that this was the way to pray. Again the Templars intervened and took him away. They apologized to me and said: 'He is a foreigner who has just arrived today from his homeland in the north, and he has never seen anyone pray facing any other direction than east.' 'I have finished my prayers,' I said, and left, stupefied by the fanatic who had been so perturbed and upset to see someone praying facing the qibla.

Translation, by E.J. Costello in 1969 from the Italian, of Francesco Gabrieli's 1957 translation of the same passage from Usamah's Memoirs. 2

2 Francesco Gabrieli, Arab Historians of the Crusades, trans. E.J. Costello (Berkeley: University of California Press, 1969), 79-80. 
When I was visiting Jerusalem, I used to go to al-Aqsa mosque, where my Templar friends were staying. Along one side of the building was a small oratory in which the Franj had set up a church. The Templars placed this spot at my disposal that I might say my prayers. One day I entered, said Allahu Akbar, and was about to begin my prayer, when a man, a Franj, threw himself upon me, grabbed me, and turned me toward the east, saying, 'Thus do we pray.' The Templars rushed forward and led him away. I then set myself to prayer once more, but this same man, seizing upon a moment of inattention, threw himself upon me yet again, turned my face to the east, and repeated once more, 'Thus do we pray.' Once again the Templars intervened, led him away, and apologized to me, saying, " $\mathrm{He}$ is a foreigner. He has just arrived from the land of the Franj and he has never seen anyone pray without turning to face east.' I answered that I had prayed enough and left, stunned by the behaviour of this demon who had been so enraged at seeing me pray while facing the direction of Mecca.

Translation, by Jon Rothschild in 1984 from the French, of Amin Maalouf's translation in 1983 of the same passage from Usamah's Memoirs. 3

${ }^{3}$ Amin Maalouf, The Crusades Through Arab Eyes, trans. Jon Rothschild (New York: Schocken Books, 1984), 128-9. 
APPENDIX B:

THE CHARGES AGAINST THE TEMPLARS 


\section{THE CHARGES MADE AGAINST THE TEMPLARS IN THEIR TRIAL1}

These are the articles on which inquiry should be made against the Order of the Knighthood of the Temple.

Firstly, that, although they declared that the Order had been solemnly established and approved by the Apostolic See, nevertheless in the reception of the brothers of the said Order, and at some time after, there were preserved and performed by the brothers those things which follow:

Namely that each in his reception, or at some time after, or as soon as a fit occasion could be found for the reception, denied Christ, sometimes Christ crucified, sometimes Jesus, and sometimes God, and sometimes the Holy Virgin, and sometimes all the saints of God, led and advised by those who received him.-- Item, [that] the brothers as a whole did this. -- Item, that the majority [of them did this].

Item, that [they did this] also sometimes after the reception.

Item, that the receptors said and taught those whom they were receiving, that Christ, or sometimes Jesus, or sometimes Christ crucified, is not the true God.

Item, that they told those whom they received that he was a false prophet.

Item, that he had not suffered nor was he crucified for the redemption of the

1 Translation by Malcolm Barber from Le Procès des Templiers (Trial documents in France).

These were the charges, as written down on August 121308 , nearly a year after the Trial began. Malcolm Barber, The Trial of the Templars, 248-52. 
human race, but on account of his sins.

Item, that neither the receptors nor those being received had a hope of achieving salvation through Jesus, and they said this, or the equivalent or similar, to those whom they received.

Item, that they made those whom they received spit on a cross, or on a representation or sculpture of the cross and an image of Christ, although sometimes those who were being received spat next [to it].

Item, that they sometimes ordered this cross be trampled underfoot.

Item, that brothers who had been received sometimes trampled on the cross.

Item, that sometimes they urinated and trampled, and caused others to urinate, on this cross, and several times they did this on Good Friday.

Item, that some of them, on that same day or another of Holy Week, were accustomed to assemble for the aforesaid trampling and urination.

Item, that they adored a certain cat, [which] sometimes appeared to them in their assembly.

Item, that they did this in contempt of Christ and the orthodox faith.

Item, that they did not believe in the sacrament of the altar. -- Item, that some them [did not believe]. -- Item, that the majority [of them did not believe].

Item, that nor [did they believe] in the other sacraments of the Church.

Item, that the priests of the Order by whom the body of Christ is consecrated did not speak the words in the canon of the mass. -- Item, that some of them [did not]. --Item, that the majority [did not].

Item, that receptors enjoined this upon them.

Item, that they believed, and thus it was told to them, that the Grand Master could absolve them from sin. -- Item, that the Visitor [could]. -- Item, that the 
preceptors [could], of whom many were laymen.

Item, that they did this de facto. -- Item, that some of them [did].

Item, that the Grand Master of the aforesaid Order confessed this, in the presence of important persons, before he was arrested.

Item that in the reception of the brothers of the said Order or at about that time, sometimes the receptor and sometimes the received were kissed on the mouth, on the navel, or on the bare stomach, and on the buttocks or the base of the spine. -- Item, [that they were kissed] sometimes on the navel. -- Item, [that they were kissed] sometimes on the base of the spine. -- Item, [that they were kissed] sometimes on the penis.

Item, that in that reception they made those who were being received swear that they would not leave the Order.

Item, that they regarded them straightway as professed brethren.

Item, that they held these receptions secretly.

Item, that there was no one present except the brothers of the said Order.

Item, that on account of this vehement suspicion had, for a long time, worked against the said Order.

Item, that it was generally held.

Item, that they told the brothers whom they received that they could have carnal relations together.

Item, that it was licit for them to do this.

Item, that they ought to do and submit to this mutually.

Item, that it was not a sin for them to do this.

Item, that they did this, or many of them [did]. -- Item, that some them [did].

Item, that in each province they had idols, namely heads, of which some had three faces, and some one, and others had a human skull. 
Item, that they adored these idols or that idol, and especially in their great chapters and assemblies.

Item, that they venerated [them].

Item, that [they venerated them] as God.

Item, that some of them [did].

Item, that the majority of those who were in the chapters [did].

Item, that they said that that head could save them.

Item, that [it could] make riches.

Item, that it gave them all the riches of the Order.

Item, that it made the trees flower.

Item, that [it made] the land germinate.

Item, that they surrounded or touched each head of the aforesaid idols with small cords, which they wore around themselves next to the shirt or the flesh.

Item, that in his reception, the aforesaid small cords or some lengths of them were given to each of the brothers.

Item, that they did this in veneration of an idol.

Item, that it was enjoined on them that they should wear the small cords around themselves, as is set out, and wear them continually, and they did this even by night.

Item, that the brothers of the said Order were generally received in the aforesaid manner.

Item, that [it was done] everywhere.

Item, that [it was done] by the majority.

Item, that those who were not willing to do the aforesaid at their reception or afterwards were killed or imprisoned.

Item, that some of them [were]. 
Item, that the majority [were].

Item, that they enjoined them, on oath, that they should not reveal the aforesaid.

Item, that [this was done] under punishment of death, or of imprisonment.

Item, that nor should they reveal the manner of reception.

Item, that neither should they dare speak about the aforesaid among themselves.

Item, that if any were found to have revealed [these things], they were punished by death or prison.

Item that they enjoined them not to confess to anyone except a brother of their Order.

Item, that the said brothers of the Order, knowing the said errors, neglected to correct them.

Item, that they neglected to inform Holy Mother Church.

Item, that they did not retreat from the observance of the aforesaid errors and the community of the aforesaid brothers, although they had the opportunity for retreating and for doing the aforesaid.

Item, that aforesaid things were done and preserved beyond the sea, in places in which the Grand Master and chapter of the said Order were at the time staying.

Item, that sometimes the aforesaid denial of Christ was done in the presence of the Grand Master and the chapter of the aforesaid.

Item, that the aforesaid things were done and observed in Cyprus.

Item, that [they were done] on this side of the sea in all kingdoms and in other places in which receptions of the aforesaid brothers were made.

Item, that the aforesaid things were observed in the whole Order generally 
and communally. -- Item, that [they were] from the statute of the aforesaid Order.

Item, that the aforesaid observances, customs, ordinances and statutes were made and observed in the whole Order, beyond the sea and on this side of the sea.

Item, that the aforesaid were from points of the Order, having been introduced by their errors after the approval of the Apostolic See.

Item, that the receptions of the brothers of the said Order were made generally in the aforesaid manner in the whole Order aforesaid.

Item, that the Grand Master of the said Order enjoined that the aforesaid be thus observed and done. -- Item, that the Visitors [did]. -- Item, that the preceptors [did]. Item, that other leaders of the said Order [did].

Item, that these self-same men observed this, and taught that it be done and preserved. -- Item, that others of them [did].

Item, that the brothers did not preserve another mode of reception in the said Order.

Item, that it is not within the memory of anyone of the Order who is living there has been observed in their time another mode [of reception].

Item, that the Grand Master, the Visitors, the preceptors and the other Masters of the said Order, having power in this, punished gravely [those] not preserving nor willing to preserve the aforesaid manner of reception and the other things above, when a complaint was brought to them.

Item, that charitable gifts in the said Order were not made as they ought, nor was hospitality offered.

Item, that they did not reckon [it] a sin in the said Order to acquire properties belonging to another by legal or illegal means. 
Item, that it was authorised by them that they should procure increase and profit to the said Order in whatever they could by legal or illegal means.

Item, that it was not reckoned a sin to commit perjury on this account.

Item, that they were accustomed to hold their chapters in secret.

Item, that [they were held] secretly, either at the first sleep or in the first vigil of the night.

Item, that [they were held] secretly, since all the other familia of the house had been sent out and the house had been closed, as they sent out all the familia on those nights when they held chapters.

Item, that [they were held] secretly, because in this way they shut themselves up when a chapter was held, as all the doors of the house and church in which they were holding the chapter they fortified so firmly that no one might nor could gain access to them or near them, nor could anyone see or hear what they were doing or saying.

Item, that [they were held] so secretly that they were accustomed to place a guard on the roof of the house or church in which they were holding the chapter, in case anyone approached the place in which they were holding the chapter.

Item, that they observed and were accustomed to observe similar secrecy, as was usual in the receiving of brothers.

Item, that this error flourishes and has flourished in the Order for a long time, since they hold the opinion, and held in the past, that the Grand Master can absolve the brothers from their sins.

Item, that the greater error flourishes and has flourished, that these hold and have held in the past that the Grand Master can absolve the brothers of the Order from sin, even [sins] not confessed which they omitted to confess on 
account of some shame or fear of the penance to be enjoined or inflicted.

Item, that the Grand Master has confessed these aforesaid errors before capture, spontaneously, in the presence of ecclesiastics and laymen dignified in the faith.

Item, that the majority of the preceptors of the Order were present.

Item that they hold and have held the aforesaid errors, not only through the opinions and beliefs of the Grand Master, but from other preceptors and especially from leading Visitors of the Order.

Item, that whatever the Grand Master, especially with his chapter, made, ordained and legislated, the whole Order had to hold and to observe and also was observed.

Item, that this power appertained to him and has resided in him from of old. Item, that the aforesaid depraved habits and errors had lasted for such a time that the Order could have been renewed in personnel once, twice or more from the time of the introduction or observation of the aforesaid errors.

Item, that...all or two-thirds of the Order, knowing the said errors, neglected to correct them.

Item, that they neglected to inform Holy Mother Church.

Item, that they did not retreat from the observance of the aforesaid errors and from the community of the said brothers, although they had the opportunity to retreat and do the aforesaid.

Item, that many brothers of the said Order, because of the filth and errors of their Order, departed, some transferring to another Order and others remaining in secular life.

Item, that on account of each of the aforesaid, great scandals have arisen against the said Order in the hearts of elevated persons, even of kings and 
princes, and have been generated in almost the whole of the Christian population.

Item, that all and each of the aforesaid have been observed and manifest among the brothers of the said Order.

Item, that concerning these things there is public talk, general opinion and repute among the brothers of the Order and outside.-- Item, that [there is] concerning the majority of the aforesaid. -- Item, that [there is] concerning others.

Item, that the Grand Master of the Order, the Visitor and the Grand Preceptors of Cyprus, Normandy and Poitou, as well as many other preceptors and some other brothers of the said Order, have confessed what is written above, both in judicial inquiry and outside, in the presence of appointed persons and also before public persons in many places.

Item, that some brothers of the said Order, knights as well as priests, also others, in the presence of our lord pope and of the lords cardinal, have confessed the aforesaid or a great part of the said errors.

Item, that [they have confessed] through the swearing of oaths by them. Item, that also they have certified the aforesaid in full consistory. 
APPENDIX C:

MAPS

187 

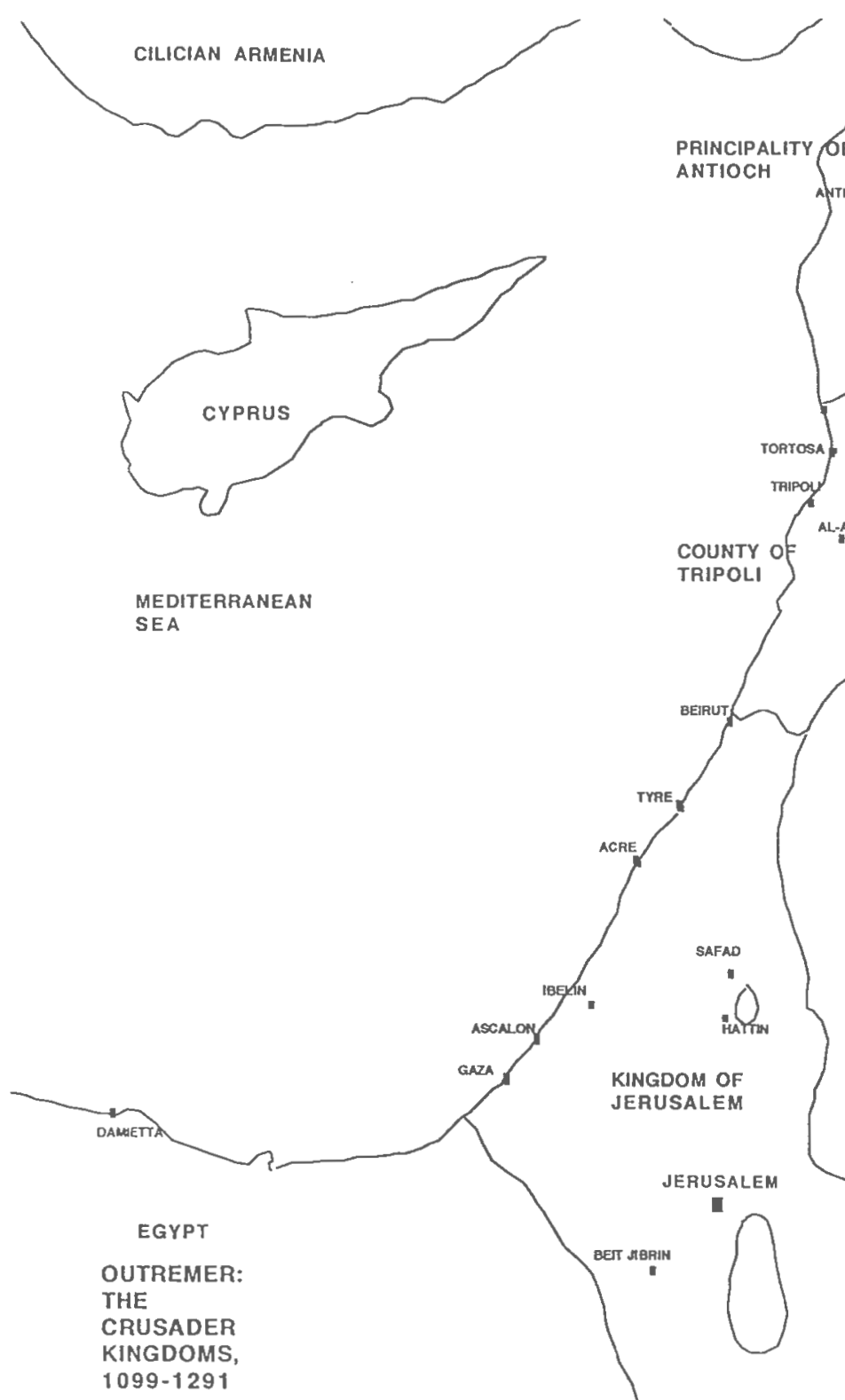

EAN

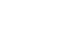




\section{BIBLIOGRAPHY}

\section{Primary Sources}

Albon, Marquis d'. Cartulaire Général de L'Ordre du Temple, 1119?-1150.

Paris: Librairie Ancienne, 1913.

Alighieri, Dante. La Divina Commedia. Cambridge: Harvard University Press, 1972.

Ancrene Wisse. Guide for Anchoresses. Translated by Hugh White. London: Penguin Books, 1993.

The Anglo-Saxon Chronicle. Dorothy Whitelock, trans. New Brunswick: Rutgers University Press, 1961.

Beha Ed-Din, Saladin, or, What Befell Sultan Yusuf (Salah Ed-Din).

Translated by C.W. Wilson. Vol. 13, Palestine Pilgrims' Text Society. London: Committee of the Palestine Exploration Fund , 1897.

Clairvaux, St. Bernard of. In Praise of the New Knighthood. The Works of Bernard of Clairvaux: Treatises 3. Vol. 7. Translated by Conrad Greenia. Kalamazoo: Cistercian Publications Inc, 1977.

Dubois, Pierre. The Recovery of the Holy Land. Translated by Walther I. Brandt. New York: Columbia University Press, 1956.

Eschenbach, Wolfram von. Parzival. Translated by André Lefevere. New York: Continuum, 1991.

Gabrieli, Francesco. Arab Historians of the Crusades. Translated by E.J. Costello. Berkeley: University of California Press, 1969.

Greenia, Conrad. "St. Bernard of Clairvaux's In Praise of the New Knighthood," ORB Index. 1996.

<http://orb.rhodes.edu/encyclop/religion/monastic/bernard.html> (25 March 1999.

Heresies of the High Middle Ages. Walter Wakefield and Austin P. Evans, trans. New York: Columbia University Press, 1969.

The Holy Bible: King James Version. New York: HarperPaperbacks, 1995.

Ibn al-Furat. Ayyubids, Mamlukes, and Crusaders: Selections from the Tarikh al-Duwal wa'l-Muluk of Ibn al-Furat. 2 vols. Cambridge: W. Heffer and Sons Ltd, 1971. 
Ibn Al-Qalanisi, The Damascus Chronicles of the Crusades. Translated by H.A.R. Gibb. London: Luzac \& Co., 1932.

Kings, Lords, and Commons: an Anthology from the Irish. Translated by Frank O'Connor. New York: Alfred A. Knopf, 1959.

Joinville, Lord John de. The Crusade of Saint Louis. Chronicles of the Crusades. London: Henry G. Bohn: 341-556, 1848.

Map, Walter. De Nugis Curialum [Courtiers' Trifles]. Translated by M.R. James. Oxford: Clarendon Press, 1983.

Moncada, Francisco de. The Catalan Chronicle of Francisco de Moncada. Translated by Frances Hernández. John M. Sharp, ed. El Paso: Texas Western Press, 1975.

Nogent, Guibert de. A Monk's Confession: The Memoirs of Guibert of Nogent. Translated by Paul J. Archambault. University Park: The Pennsylvania State University Press, 1996.

The Pact of 'Umar.' The Medieval Record: Sources of Medieval History. Translated by T.W. Arnold. Alfred J. Andrea, ed. Boston: Houghton Mifflin Company, 1997: 93-4.

Paris, Matthew. Matthew Paris's English History: From the Year 1235 to 1273. 3 vols. New York: AMS Press, 1853; reprint, 1968.

Le procès des Templiers [The Trial of the Templars]. 2 vols. Jules Michelet, ed. 1841, reprint, Paris: Les Éditions du C.T.H.S., 1987.

Recueil des historiens des Croisades [Anthology of the Historians of the Crusades]. 15 vols. Paris: Imprimerie Nationale, [1872].

La Règle des Templiers [The Rule of the Templars]. Laurent Dailliez, ed. Nice: Alpes-Méditerranée Editions, 1977.

La Règle du Temple [The Rule of the Temple]. Henri de Curzon, ed. Paris: La Société de l'Histoire de France, 1886; reprint, 1977.

The Rule of the Templars: The French Text of the Rule of the Order of the Knights Templar. Translated by J.M. Upton-Ward. Vol. 4, Studies in the History of Medieval Religion. Woodbridge: The Boydell Press, 1992.

Syrien, Michel le, Chronique de Michel le Syrien [Chronicle of Michael the Syrian]. 2 vols. Translated by J.B. Chabot. Paris: Ernest Leroux, 1899. 
Theodorich. Guide to the Holy Land. Translated by Aubrey Stewart. 2nd ed. New York: Italica Press, 1986.

Troyes, Chrétien de, The Complete Romances of Chrétien de Troyes.

Translated by David Staines. Bloomington: Indiana University Press, 1990.

Tyre,The Templar of. Chronique du Templier de Tyr. Les Gestes des Chiprois: recueil de chroniques francaises [The deeds of the Cypriots: a collection of French chronicles]. Gaston Raynaud, ed. Genève: Imprimerie Jules-Guillaume Fick, 1887.

Tyre, William, Archbishop of. A History of Deeds Done Beyond the Sea. 2 vols. Translated by Emily Atwater Babcock. New York: Columbia University Press, 1943.

Upton-Ward, Judith. "Military Orders: The Primitive Rule of the Templars," ORB index. n.d. <http://orb.rhodes.edu/encyclop/religion/monastic/T_Rule.html> (25 March 1999).

Usamah Ibn Munqidh. An Arab-Syrian Gentleman and Warrior in the Period of the Crusades: Memoirs of Usamah Ibn-Munqidh. Translated by Philip K. Hitti. New York: Columbia University Press, 1929.

\section{Secondary Sources}

Aberconway, Christabel, ed. A Dictionary of Cat Lovers, XV Century B.C.--XX Century A.D. London: Michael Joseph, 1950.

Addison, Charles G. The History of the Knights Templars, the Temple Church, and the Temple. Kempton: Adventures Unlimited Press, 1842; reprint, 1997.

Annan, David. The Ku Klux Klan. Secret Societies. Norman MacKenzie, ed. London: Aldus Books: 266-97, 1967.

Armstrong, Karen. Jerusalem: One City, Three Faiths. New York: Alfred A. Knopf, 1996.

Arnold, Udo. Eight Hundred Years of the Teutonic Order. The Military Orders: Fighting for the Faith and Caring for the Sick. Malcolm Barber, ed., 223-35. Cambridge: Variorum, 1994.

ASSI Publishing. T.E.M.P.L.A.R. (Theology of the Egyptian Magi Priests Loyal to the Ancient Rites), Sollog's Homepage. 1999. <http://www.sollog.com/booktemplar.shtml> (25 March 1999). 
Atiya, Aziz S. Crusade, Commerce and Culture. Bloomington: Indiana University Press, 1962.

Avenging Angel. Highlander: The Series. Written by Fabrice Ziolkowski. Produced by Barry Rosen and Gary Goodman. Directed by Paolo Barzman. 50 min. Gaumont Télévision, 1993.

Baálbaki, Munir. Al-Mawrid [A Modern English-Arabic Dictionary]. 13th ed. Beirut: Dar-El-IIm Lit-Malayen, 1967.

Baigent, Michael, Leigh, Richard, and Lincoln, Henry. Holy Blood, Holy Grail. New York: Dell Publishing, 1982.

Baigent, Michael, Leigh, Richard, and Lincoln, Henry. The Messianic Legacy. New York: Dell Publishing, 1986.

Baigent, Michael and Leigh, Richard. The Temple and the Lodge. New York: Arcade Publishing, 1989.

Barber, Malcolm. The New Knighthood: A History of the Order of the Temple. Cambridge: Cambridge University Press, 1994.

Barber, Malcolm. Lepers, Jews and Moslems: The Plot to Overthrow Christendom in 1321. History 66, no. 216 (February 1981): 1-17.

Barber, Malcolm. The Templars and the Turin Shroud. The Catholic Historical Review 68 (1982): 206-25.

Barber, Malcolm. The Trial of the Templars. Cambridge: Cambridge University Press, 1978.

Barber, Richard. The Knight and Chivalry. Totowa: Rowman and Littlefield, 1975.

Bashiruddin, S. The Fate of Sectarian Libraries in Medieval Islam. Libri 17 no. 3 (1967): 149-62.

Ben-Ami, Aharon. Social Change in a Hostile Environment: The Crusaders' Kingdom of Jerusalem. Princeton: Princeton University Press, 1969.

Bennett, Matthew. La Règle du Temple as a Military Manual, or How to Deliver a Cavalry Charge. In Studies in Medieval History Presented to R. Allen Brown, ed. Christopher Harper-Bill, Christopher J. Holdsworth, and Janet L. Nelson, 7-19. Woodbridge: The Boydell Press: 1989. 
Benvenisti, Meron. The Crusaders in the Holy Land. New York: The Macmillan Company, 1970.

Blackburne, Linda. Fear of the Not So Secret Brothers (Masonic Lodges and Schools). Times Educational Supplement. no. 4019 (9 July 1993): 8.

Bordonove, Georges. La vie quotidienne des Templiers au XIII siècle [The Daily Life of the Knights Templar in the 13th Century]. Paris: Hachette, 1975.

Bordonove, Georges. Philippe le Bel: roi de fer [Philip the Fair: King of Fire]. Les rois qui ont fait France. Paris: Pygmalion, 1984.

Boswell, John. Christianity, Social Tolerance, and Homosexuality: Gay People in Western Europe from the Beginning of the Christian Era to the Fourteenth Century. Chicago: The University of Chicago Press, 1980.

Bowersock, G.W. Roman Arabia. Cambridge: Harvard University Press, 1983; reprint, 1994.

Brady, Laura. Essential and Despised: Images of Women in the First and Second Crusades, 1095-1148. MA Thesis, University of Windsor, 1992.

Brown, Elizabeth R. The Prince is Father of the King: The Character and Childhood of Philip the Fair of France. Mediaeval Studies 49 (1987): 282-334.

Brown, J.A.C. Techniques of Persuasion: From Propaganda to Brainwashing Middlesex: Penguin Books, 1963.

Brundage, James A. Marriage Law in the Latin Kingdom of Jerusalem.

Outremer: Studies in the History of the Crusading Kingdom of Jerusalem. B.Z. Kedar, H.E. Mayer, and R.C. Smail, eds., 258-270. Jerusalem: Yad Izhak BenZvi Institute: 1982.

Bull, Marcus. Origins. The Oxford lllustrated History of the Crusades. Jonathan Riley-Smith, ed., 13-33. Oxford: Oxford University Press: 1995.

Bullock, Steven C. Revolutionary Brotherhood: Freemasonry and the Transformation of the American Social Order, 1730-1840. Chapel Hill: University of North Carolina Press, 1996.

Burman, Edward. The Templars: Knights of God. Rochester: Destiny Books, 1986. 
Burns, Robert Ignatius. Islam Under the Crusaders: Colonial Survival in the Thirteenth-Century Kingdom of Valencia. Princeton: Princeton University Press, 1973.

Campbell, G.A. The Knights Templars: Their Rise and Fall. London:

Duckworth, 1937; reprint, 1980.

Cantor, Norman F. The Civilization of the Middle Ages. 4th ed. New York: HarperPerennial, 1994.

Caplan, Lionel. Studies in Religious Fundamentalism. Albany: State University of New York Press, 1987.

Cohn, Norman. Europe's Inner Demons: An Enquiry Inspired by the Great Witch-Hunt. New York: Basic Books, 1975.

The Compact Edition of the Oxford English Dictionary. 2 vols. Oxford: Oxford University Press, 1971; reprint 1984.

Contamine, Philippe. War in the Middle Ages. Translated by Michael Jones. Oxford: Basil Blackwell Ltd, 1984.

Dafoe, Stephen. "A History and Mythos of the Knights Templar," Templar Books. n.d. <http://intranet.ca/ magicworks/knights/next.html> (25 March 1999).

Dailliez, Laurent. Bibliographie du Temple. Paris: Diplômé de l'Ecole Pratique des Hautes-Etudes, 1980?

Daniel, Norman. Heroes and Saracens: An Interpretation of the Chansons de Geste. Edinburgh: Edinburgh University Press, 1984.

Daniel, Norman. Islam and the West: The Making of an Image. Edinburgh: The University Press, 1960; reprint, 1962.

Daftary, Farhad. The Isma'ilis: Their History and Doctrines. Cambridge: Cambridge University Press, 1990.

DeGategno, Paul J. Ivanhoe: The Mask of Chivalry. Twayne's Masterwork Studies no. 125. New York: Twayne Publishers, 1994.

Delort, Robert. Les animaux ont une histoire The History of Animals]. Paris: Éditions du Seuil, 1984. 
Demurger, Alain. Vie et mort de l'ordre du Temple, 1120-1314. Paris: Éditions du Seuil, 1989.

Denny, Frederick Mathewson. An Introduction to Islam. 2d ed. New York: Macmillan Publishing Company, 1994.

De Roover, Raymond. Money, Banking and Credit in Mediaeval Bruges: Italian Merchant-Bankers Lombards, and Money-Changers, a Study in the Origins of Banking. Cambridge: The Mediaeval Academy of America, 1948.

Downes, Larry and Mui, Chunka. Unleashing the Killer App: Digital Strategies for Market Dominance. Boston: Harvard Business School Press, 1998.

Duby, Georges. The Three Orders: Feudal Society Imagined. Translated by Arthur Goldhammer. Chicago: The University of Chicago Press, 1980.

Eco, Umberto. Foucault's Pendulum. Translated by William Weaver. New York: Ballantine Books, 1990.

Edbury, Peter W. The Kingdom of Cyprus and the Crusades, 1191-1374. Cambridge: Cambridge University Press, 1991.

Ehrenkreutz, Andrew S. Saladin. Albany: State University of New York Press, 1972.

Eisenstein, Sergei. Alexander Nevsky. Directed by Sergei Eisenstein. 110 $\min , 1938$, videocassette.

Eliséeff, Nikita. The Reaction of the Syrian Muslims After the Foundation of the First Latin Kingdom of Jerusalem. Crusaders and Muslims in Twelfth Century Syria. Maya Shatzmiller, ed., 162-72. Leiden: E.J. Brill: 1993.

Emery, Richard W. The Jews of Perpignan in the Thirteenth Century: An Economic Study Based on Notarial Records. New York: Columbia University Press, 1959.

Evans, G.R. The Mind of St. Bernard of Clairvaux. Oxford: Clarendon Press, 1983.

Favier, Jean. Philippe le Bel. Paris: Fayard, 1978.

Finucane, Ronald C. Soldiers of the Faith: Crusaders and Moslems at War. New York: St. Martin's Press, 1983. 
Forey, A.J. The Military Orders and the Spanish Reconquest in the Twelfth and Thirteenth Centuries. Military Orders and the Crusades, 197-234. Aldershot: Variorum: 1994.

Forey, A.J. The Military Orders: From the Twelfth to the Early Fourteenth Centuries. Toronto: University of Toronto Press, 1992.

Forey, A.J. The Templars in the Corona de Aragón. London: Oxford University Press, 1973.

Forey, A.J. The Will of Alfonso I of Aragon and Navarre. Durham University Journal, 73 (December 1980): 59-65.

Forey, A.J. The Military Orders, 1120-1312. The Oxford lllustrated History of the Crusades. Jonathan Riley-Smith, ed.,184-216. Oxford: Oxford University Press: 1995.

Forey, A.J. Women and the Military Orders in the Twelfth and Thirteenth Centuries. Military Orders and the Crusades, 63-92. Aldershot: Variorum: 1994.

Freemasons Are Not Interested in Politics. Moscow News. No. 33-6 (15 September 1995): p. 22.

Fuller, Thomas. A History of the Holy Warre. London: William Pickering, 1639; reprint, 1840.

Galahad, Fr. "Knights Templar Oasis," Ordo Templi Orientis: U.S. Grand Lodge. n.d. <http://www.kto.org/> (25 March 1999).

Geary, Patrick J. Furta Sacra: Thefts of Relics in the Central Middle Ages. Princeton: Princeton University Press, 1978.

Gibbon, Edward. The History of the Decline and Fall of the Roman Empire. 6 vols. Philadephia: John D. Morris \& Company, 1912.

Gilmour-Bryson, Anne. Sodomy and the Knights Templar. Journal of the History of Sexuality 7, no. 2 (1996): 151-83.

Glick, Thomas F. Islamic and Christian Spain in the Early Middle Ages.

Princeton: Princeton University Press, 1979.

Goodison, Lucy and Morris, Christine. Exploring Female Divinity: From Modern Myths to Ancient Evidence. Ancient Goddesses: The Myths and the Evidence. London: British Museum Press, 1998. 
Grayson, Timothy. Templar Strategies Homepage. n.d.

$<$ http://www.templar.ca/ (25 March 1999).

Hannah, Walton. Darkness Visible: A Revelation and Interpretation of Freemasonry. London: Augustine Press, 1953.

Heath, Peter. The Thirsty Sword: Sirat 'Antar and the Arabic Popular Epic. Salt Lake City: University of Utah Press, 1996.

Heckethorn, Charles William. Secret Societies of All Ages and Countries. 2 vols. New York: University Press, 1965.

Heller, John H. Report on the Shroud of Turin. Boston: Houghton Mifflin Company, 1983.

Hillgarth, J.N. Ramon Lull and Lullism in Fourteenth-Century France. Oxford: Clarendon Press, 1971.

Hitti, Philip K. History of the Arabs: from the Earliest Times to the Present. New York: St. Martin's Press, 1968.

Hitti, Philip K. Makers of Arab History. New York: St. Martin's Press, 1968.

Hoare, Rodney. The Turin Shroud is Genuine: The Irrefutable Evidence. 2nd ed. New York: Barnes \& Noble Books, 1994.

Holt, P.M. The Age of the Crusades: The Near East from the Eleventh Century to 1517. London: Longman Group Limited, 1986.

"Introduction to Templar," PJO Publications Inc. Homepage. n.d.. $<$ <ttp://www.wenet.net:81/ pjopubs/example.html> (25 March 1999).

Irwin, Robert . Islam and the Crusades, 1096-1699. The Oxford Illustrated History of the Crusades. Jonathan Riley-Smith, ed.,217-67. Oxford: Oxford University Press: 1995.

Ivanhoe. Written by Noel Langley. Directed by Richard Thorpe. Produced by Pandro S. Berman. 107 min. Metro Goldwyn Mayer Inc, 1952. Videocassette.

Ivanhoe. Written by John Gay. Directed by Douglas Camfield. Produced by Norman Rosemont. 142 min. Columbia Pictures Television, 1982. Videocassette.

Ivanhoe. Written by Deborah Cook. Directed by Stuart Orme. Produced by Jeremy Gwilt. 300 min. BBC TVIA\&E Home Video, 1997. Videocassette. 
Jackson, Peter. The Crusades of 1239-41 and Their Aftermath. Bulletin of the School of Oriental and African Studies. 50 (1987): 32-60.

Jenner, Mark S.R. The Great Dog Massacre. Fear in Early Modern Society. William G. Naphy and Penny Roberts, eds. Manchester: Manchester University Press, 1997.

Jacoby, David. Les communes italiennes et les ordres militaires à Acre: aspects juridiques, territoriaux et militaires [The Italian Communes and the Military Orders at Acre: Judicial, Territorial and Military Aspects] (1104-1187, 1191-1291). Etat et colonization au Moyen Age et à la Renaissance [State and Colonisation in the Middle Ages and the Renaissance]. Michel Balard, ed., 193-214. Lyon: la manufacture, 1989.

Kaplan, Lawrence. Fundamentalism in Comparative Perspective. Amherst: The University of Massachusetts Press, 1992.

Karlsen, Carol F. The Devil in the Shape of a Woman: Witchcraft in Colonial New England. New York: W.W. Norton \& Company, 1987.

Katz, Jacob. Jews and Freemasons in Europe, 1723-1939. Translated by Leonard Oschry. Cambridge: Harvard, 1970.

Kedar, Benjamin Z. The Subjected Muslims of the Frankish Levant. Muslims Under Latin Rule, 1100-1300. James M. Powell, ed., 135-174. Princeton: Princeton University Press, 1990.

Keen, Maurice. Chivalry. New Haven: Yale University Press, 1984.

Kersten, Holger and Gruber, Elmar R. The Jesus Conspiracy: The Turin Shroud and the Truth About the Resurrection. Rockport: Element, 1992.

Knight, Stephen. Jack the Ripper: The Final Solution. St. Albans: Panther, 1977.

The Knights Templar. Ancient Warriors. Written, directed, and produced by Phil Grabsky. 20 min. Seventh Art Productions for The Learning Channel, 1994.

The Knights Templar. In Search of History. Produced by Steven R. Talley. 40 min. FilmRoos Inc. for the History Channel, 1997.

The Knights Templar. Terra X. Written by Rob Goldberg. Edited by Joe Camperiati. $20 \mathrm{~min}$. Produced by ZDF/ARTE for Discovery Channel, 1995. 
Kurtz, Katharine and Harris, Deborah Turner. The Adept. New York: Ace Books, 1991.

Kurtz, Katharine and Harris, Deborah Turner. The Adept, Book Two: Lodge of the Lynx. New York: Ace Books, 1992.

Kurtz, Katharine and Harris, Deborah Turner. The Adept, Book Three: The Templar Treasure. New York: Ace Books, 1993.

Kurtz, Katharine and Harris, Deborah Turner. The Adept, Book Four: Dagger Magic. New York: Ace Books, 1995.

Kurtz, Katharine and Harris, Deborah Turner. The Adept, Book Five: Death of an Adept. New York: Ace Books, 1996.

Kurtz, Katherine. Obligations. Tales of the Knights Templar. Katherine Kurtz, ed, 96-128. New York: Warner Books: 1995.

Kurtz, Katherine. On Crusade: More Tales of the Knights Templar. Katherine Kurtz, ed. New York: Warner Books: 1998.

Laughing Owl Bookstore. 23 March 1999. <http://www.laughingowl.com> (25 March 1999).

La Monte, John L. Feudal Monarchy in the Latin Kingdom of Jerusalem, 1100 to 1291 Cambridge: The Mediaeval Academy of America, 1932.

Lambert, Malcolm. Medieval Heresy: Popular Movements from Bogomil to Hus. New York: Holmes and Meier Publishers, 1977.

Lawrence, C.H. Medieval Monasticism. New York: Longman Group Ltd, 1984.

Legman, G. The Guilt of the Templars. New York: Basic Books, Inc, 1966.

Le Goff, Jacques. The Usurer and Purgatory. The Dawn of Modern Banking. Center for Medieval and Renaissance Studies,25-52. New Haven: Yale University Press: 1979.

Le Goff, Jacques. Your Money or Your Life. Translated by Patricia Ranum. New York: Zone Books, 1988.

Lewis, Bernard. The Assassins: A Radical Sect in Islam. London: Weidenfield and Nicolson, 1967. 
Linehan, Peter. History and the Historians of Medieval Spain. Oxford:

Clarendon Press, 1993.

Lloyd, Simon. Review of The Rule of the Templars: The French Text of the Rule of the Order of the Knights Templar (translated by J.M. Upton-Ward). The Journal of Ecclesiastical History. 44 (April 1993): 337-8.

Lopez, Robert S. The Dawn of Medieval Banking. The Dawn of Modern Banking. Center for Medieval and Renaissance Studies, 1-23. New Haven: Yale University Press, 1979.

Lourie, Elena. The Will of Alfonso I of Aragon and Navarre: A Reply to Dr. Forey. Durham University Journal 77 (June 1985): 165-72.

Lourie, Elena. The Will of Alfonso I, "El Batallador," King of Aragon and Navarre: A Reassessment. Durham University Journal 50 (October 1975): 635-51.

"Lyrics," Templars Homepage. n.d.

<http://www.geocities.com/SunsetStrip/Palms/4907/page2.html> (25 March 1999).

Maalouf, Amin. The Crusades Through Arab Eyes. Translated by Jon Rothschild. New York: Schocken Books, 1984.

Malek, Jaromir. The Cat in Ancient Egypt. Philadelphia: University of Pennsylvania Press, 1993.

Mann, William F. "The Knights Templar and the 'Holy Grail' in Nova Scotia," The Labyrinth of the Grail. n.d. <http://www.gate.net/ grupo/grail.html> (25 March 1999).

Markowski, Michael. "Crusade Society: SSCLE," SSCLE Homepage. 8 January 1999. <http://www.wcslc.edu/pers_pages/m-markow/ssclehome.html> (25 March 1999).

Marschner, Heinrich, Ivanhoe, or, The Jewess. Philadelphia: American Opera Publishing Company, 1829.

Martin, Edward J. The Trial of the Templars. Cleveland: AMS, 1928; reprint, 1978.

Maurer, Jane. "CSE History Dept: Middle East Medievalists," MEM Homepage. n.d. <http://www.colostate.edu/Depts/Hist/mem/index.html> (25 March 1999). 
McCrone, Walter C. Judgement Day for the Turin Shroud. Chicago: Microscope Publications, 1996.

Menache, Sophie. The Templar Order: a failed ideal? The Catholic Historical Review 79, no. 1 (January 1993): 1-21.

Mendonça, António. "The Knights Templar in the Portuguese Discoveries," The Knights Templar. 1998. <http://www.euroknightstemplar.org/> (25 March 1999).

Metcalf, D.M. The Templars as Bankers and Monetary Transfers between West and East in the Twelfth Century. Coinage in the Latin East: The Fourth Oxford Symposium on Coinage and Monetary History. P.W. Edbury and D.M. Metcalf, eds., 1-17. B.A.R. International Series, no. 77 Oxford: B.A.R.: 1980.

Mollat, G. The Popes at Avignon, 1305-1378. Translated by Janet Love. Thomas Nelson \& Sons, 1963; reprint 1965.

Morgan, M.R. The Chronicle of Ernoul and the Continuations of William of Tyre. Oxford: Oxford University Press, 1973.

Morris, Wentworth S. Amphibious Siegecraft in the Fifth Crusade: The Siege of Damietta, 1218-1219. Athens: Th. \& Ath. loannidis Brothers, 1967(?).

Munro, John $\mathrm{H}$. Bullionism and the Bill of Exchange in England. The Dawn of Modern Banking. Center for Medieval and Renaissance Studies, 169-239. New Haven: Yale University Press, 1979.

Nielsen Jr. , Niels C. Fundamentalism, Mythos, and World Religions. Albany: State University of New York Press, 1993.

Nicholson, Helen. Knights and Lovers: The Military Orders in the Romantic Literature of the Thirteenth Century. The Military Orders: Fighting for the Faith and Caring for the Sick. Malcolm Barber, ed., 340-5. Cambridge: Variorum: 1994.

Nicholson, Helen. Saints or Sinners? The Knights Templar in Medieval Europe. History Today 44 (1994): 30-6.

Nicholson, Helen. Templars, Hospitallers and Teutonic Knights: Images of the Military Orders, 1128-1291. Leicester: Leicester University Press, 1993.

Nickell, Joe. Inquest on the Shroud of Turin. Buffalo: Prometheus Books, 1983. 
Nirenberg, David. Communities of Violence: Persecution of Minorities in the Middle Ages. Princeton: Princeton University Press, 1996.

Nirenberg, David. Violence and Persecution of Minorities in the Crown of Aragon: Jews, Lepers, and Muslims before the Black Death. Ph.D diss., Princeton University, 1992.

O'Callaghan, Joseph F. The Mudejars of Castile and Portugal in the Twelfth and Thirteenth Centuries. James M. Powell, ed., 11-56. Muslims Under Latin Rule, 1100-1300. Princeton: Princeton University Press: 1990.

Oldenbourg, Zoé. Massacre at Montségur: A History of the Albigensian Crusade. Translated by Peter Green. New York: Minerva Press, 1968.

Olson, Glenn. Italian Merchants and the Performance of Papal Banking Functions in the Early Thirteenth Century. Economy, Society, and Government in Medieval Italy: Essays in Memory of Robert L. Reynolds. David Herlihy, Robert S. Lopez, and Vsevolod Slessarov, eds., 43-63. Kent: The Kent State University Press: 1969.

Partner, Peter. The Knights Templar and Their Myth The Murdered Magicians]. 2nd ed. Rochester: Destiny Books, 1990.

Pegues, Franklin J. The Lawyers of the Last Capetians. Princeton: Princeton University Press, 1962.

Picknett, Lynn and Prince, Clive. Turin Shroud: In Whose Image? New York: HarperCollins Publishers, 1994.

Poliakov, Léon. Jewish Bankers and the Holy See: From the Thirteenth to the Seventeenth Century. Translated by Miriam Kochan. London: Routledge and Kegan Paul, 1977.

Powell, James M., ed. Muslims Under Latin Rule, 1110-1300. Princeton: Princeton University Press, 1990.

Powell, James M. The Papacy and the Muslim Frontier. Muslims under Latin Rule, 1110-1300. Powell, James M., ed., 175-204. Princeton: Princeton University Press: 1990.

Prawer, Joshua. Crusader Institutions. Oxford: Clarendon Press, 1980.

Prawer, Joshua. The Crusaders' Kingdom: European Colonialism in the Middle Ages. New York: Praeger Publishers, 1972. 
Pryor, John $\mathrm{H}$. Transportation of Horses by Sea During the Era of the Crusades. Part I. The Mariner's Mirror 68, no. 1 (1982): 9-27.

Read, Jan. The Moors in Spain and Portugal. London: Faber and Faber, 1974.

Richards, Jeffrey. Sex, Dissidence and Damnation: Minority Groups in the Middle Ages. New York: Routledge, 1994.

Robison, John. Proofs of a Conspiracy. Boston: The Americanist Classics, 1798, reprint, 1967.

Robinson, John J. Born in Blood: The Lost Secrets of Freemasonry. New York: M. Evans \& Company, 1989.

Robinson, John J. Dungeon, Fire and Sword: The Knights Templar in the Crusades. New York: M. Evans \& Co., 1991.

Rocquain, Félix. Two Hostile Sovereigns at the Brink. Philip the Fair and Boniface VIII: State vs. Papacy. Charles T. Wood, ed., 47-52. New York: Holt, Rinehart and Winston: 1967.

Rogers, Katharine M. The Cat and the Human Imagination: Feline Images from Bast to Gartield. Ann Arbor: University of Michigan Press, 1998.

Sacred Societies. The Unexplained. Written and produced by Neil Laird. 40 min. Tower Productions Inc. for the A\&E Network, 1999.

Sargent, William. Battle For the Mind: A Physiology of Conversion and BrainWashing. Garden City: Doubleday and Company, 1957.

Scott, Sir Walter. Ivanhoe: A Romance. Philadelphia: Porter and Coates, 1819; reprint, 1830.

Scott, Sir Walter. The Talisman: A Tale of the Crusaders. New York: Peter Fenelon Collier \& Son, 1825, reprint, 1900.

Seward, Desmond. The Monks of War: The Military Religious Orders. 2nd ed. London: Penguin Books, 1995.

The Shadow of the Templars. Ancient Mysteries, Written and narrated by Henry Lincoln. Researched by Richard Leigh, Michael Baigent, Anthony Walls, and Jania. MacGillivray. 40 min. BBC [A\&E Channel], 1979.

Siberry, Elizabeth. Criticism of Crusading, 1095-1274. Oxford: Clarendon Press, 1985. 
Siberry, Elizabeth. Victorian Perceptions of the Military Orders. The Military Orders: Fighting for the Faith and Caring for the Sick. Malcolm Barber, ed., 365-72. Cambridge: Variorum: 1994.

Sniffing the Guantlet. Wishbone. Written by Darla Opava. Directed and produced by Rick Duffield. 20 min. Big Feats! Entertainment, 1995.

A Symposium. The Crusading Kingdom of Jerusalem--The First European Colonial Society? The Horns of Hattin. B.Z. Kedar, ed., 341-66. Jerusalem: Yad Izhak Ben-Zvi: 1992.

Smail, R.C. Crusading Warfare, 1097-1193. 2nd ed. Cambridge: Cambridge University Press, 1995.

Smail, R.C. The Predicaments of Guy of Lusignan, 1183-87. Outremer: Studies in the History of the Crusading Kingdom of Jerusalem. B.Z. Kedar, H.E. Mayer, and R.C. Smail, eds., 159-76. Jerusalem: Yad Izhak Ben-Zvi Institute: 1982.

Spielberg, Steven. Indiana Jones and the Last Crusade. Directed by Steven Spielberg. $126 \mathrm{~min}$. Produced by Lucasfilm Ltd. 1989. Videocassette.

Steffes, Joe. The Commandery of Antioch Title Page. 11 November, 1998. <http://www.provide.net/ templar/s (25 March 1999).

Stevenson, David. The Origins of Freemasonry: Scotland's Century, 15901710. Cambridge: Cambridge University Press, 1988.

Strayer, Joseph R. Italian Bankers and Philip the Fair. Economy, Society, and Government in Medieval ltaly: Essays in Memory of Robert L. Reynolds. David Herlihy, Robert S. Lopez, and Vsevolod Slessarov, eds., 113-21. Kent: The Kent State University Press: 1969.

Tate, Georges. The Crusaders: Warriors of God. Translated by Lory Frankel. New York: Henry N. Abrams, Inc., 1996.

"The Templars Main Page," Templars Homepage. n.d.

<http://www.geocities.com/SunsetStrip/Palms/4907/page2.html> (25 March 1999).

Toynbee, Paget. A Dictionary of Proper Names and Notable Matters in the Works of Dante. Oxford: Clarendon Press, 1968.

Tuchman, Barbara. A Distant Mirror: The Calamitous 14th Century. New York: Alfred A. Knopf, Inc., 1978. 
Tyerman, Christopher Who Went on Crusades? The Horns of Hattin. B.Z.

Kedar ed., 13-26. Jerusalem: Yad Izhak Ben-Zvi:. 1992.

Unger, Richard W. The Ship in the Medieval Economy, 600-1600. London:

Croom Helm Limited, 1980.

Voltaire. Philosophical Dictionary [Dictionnaire philosophiquel. Translated by Theodore Besterman. London: Penguin Books, 1972.

Wacher, John. Roman Britain. London: J.M. Dent \& Sons Ltd., 1978.

Wakefield, Walter L. Heresy, Crusade and Inquisition in Southern France, 1100-1250. Berkeley: University of California Press, 1974.

Walker, Robert. "The Templar Knights," The RobFAQ. 20 January 1999.

$<$ http://www.iwaynet.net/ rwalker/templar.html> (25 March 1999).

Watson, William. Beltran in Exile. London: Chatto \& Windus, 1979.

Weston, Jessie L. The Quest of the Holy Grail. New York: Barnes \& Noble, Inc., 1913; reprint, 1964.

Wetzel, Lilian. Le Concile de Vienne(1312-1332): et l'Abolition de L'Ordre du Temple. Paris: Editions Dervy, 1993.

Wickens, Karen Ann. Military Ethics for Christians, Knights and Soldiers. Th.D thesis, Harvard University, 1994.

Wilkin, Gregory. "The Dissolution of the Templar Ideal in Sir Gawain and the Green Knight." English Studies 63 (1982): 109-121.

Williams, Loretta J. Black Freemasonry and Middle-Class Realities. Columbia: University of Missouri Press, 1980.

Wilson, lan. The Shroud of Turin: The Burial Cloth of Jesus Christ? New York: Doubleday \& Company, Inc., 1978. 